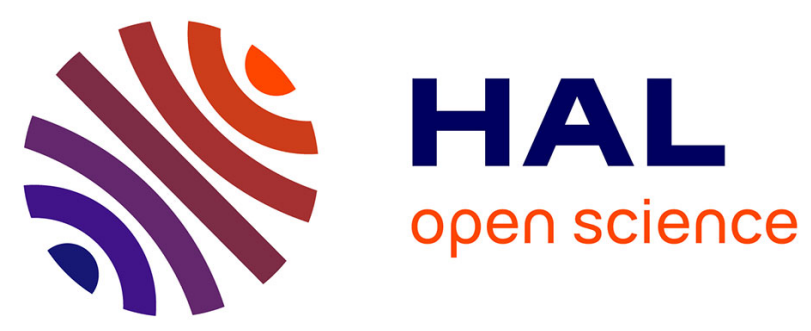

\title{
Geochronology and geochemistry of Eocene-aged volcanic rocks around the Bafra (Samsun, N Turkey) area: Constraints for the interaction of lithospheric mantle and crustal melts
}

Irfan Temizel, Mehmet Arslan, Cem Yücel, Emel Abdioğlu, Gilles Ruffet

\section{To cite this version:}

Irfan Temizel, Mehmet Arslan, Cem Yücel, Emel Abdioğlu, Gilles Ruffet. Geochronology and geochemistry of Eocene-aged volcanic rocks around the Bafra (Samsun, N Turkey) area: Constraints for the interaction of lithospheric mantle and crustal melts. Lithos, 2016, 258-259, pp.92-114. 10.1016/j.lithos.2016.04.023 . insu-01312974

\section{HAL Id: insu-01312974 \\ https://hal-insu.archives-ouvertes.fr/insu-01312974}

Submitted on 9 May 2016

HAL is a multi-disciplinary open access archive for the deposit and dissemination of scientific research documents, whether they are published or not. The documents may come from teaching and research institutions in France or abroad, or from public or private research centers.
L'archive ouverte pluridisciplinaire HAL, est destinée au dépôt et à la diffusion de documents scientifiques de niveau recherche, publiés ou non, émanant des établissements d'enseignement et de recherche français ou étrangers, des laboratoires publics ou privés. 


\section{Accepted Manuscript}

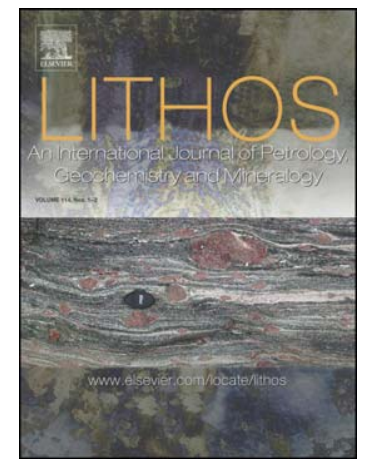

Geochronology and geochemistry of Eocene-aged volcanic rocks around the Bafra (Samsun, N Turkey) area: Constraints for the interaction of lithospheric mantle and crustal melts

İrfan Temizel, Mehmet Arslan, Cem Yücel, Emel Abdioğlu, Gilles Ruffet

PII: $\quad$ S0024-4937(16)30058-5

DOI: $\quad$ doi: $10.1016 /$ j.lithos.2016.04.023

Reference: $\quad$ LITHOS 3909

To appear in: $\quad$ LITHOS

Received date: 28 October 2015

Accepted date: $\quad 20$ April 2016

Please cite this article as: Temizel, İrfan, Arslan, Mehmet, Yücel, Cem, Abdioğlu, Emel, Ruffet, Gilles, Geochronology and geochemistry of Eocene-aged volcanic rocks around the Bafra (Samsun, N Turkey) area: Constraints for the interaction of lithospheric mantle and crustal melts, LITHOS (2016), doi: 10.1016/j.lithos.2016.04.023

This is a PDF file of an unedited manuscript that has been accepted for publication. As a service to our customers we are providing this early version of the manuscript. The manuscript will undergo copyediting, typesetting, and review of the resulting proof before it is published in its final form. Please note that during the production process errors may be discovered which could affect the content, and all legal disclaimers that apply to the journal pertain. 


\title{
Geochronology and geochemistry of Eocene-aged volcanic rocks around the Bafra (Samsun, N Turkey) area: constraints for the interaction of lithospheric mantle and crustal melts
}

\author{
İrfan Temizel ${ }^{\mathrm{a} *}$, Mehmet Arslan ${ }^{\mathrm{a}}$, Cem Yücel ${ }^{\mathrm{b}}$, Emel Abdioğlu $^{\mathrm{a}}$, Gilles Ruffet ${ }^{\mathrm{c}}$ \\ ${ }^{a}$ Department of Geological Engineering, Karadeniz Technical University, TR-61080, Trabzon, Turkey \\ ${ }^{b}$ Department of Mining Engineering, Gümüşhane University, TR-29000, Gümüşhane, Turkey \\ ${ }^{c}$ Géosciences Rennes, UPR CNRS 4661, 35042 Rennes, Cedex, France \\ *Corresponding author. Email: itemizel@ktu.edu.tr
}

\begin{abstract}
${ }^{40} \mathrm{Ar}-{ }^{39} \mathrm{Ar}$ age, whole-rock chemical and $\mathrm{Sr}-\mathrm{Nd}$ isotope data are presented for the post-collisional, Eocene (51.3-44.1 Ma)-aged volcanic rocks from the Bafra (Samsun) area in the western part of the Eastern Pontides (N Turkey) aiming to unravel their sources and evolutionary history. The studied Eocene volcanic rocks can be divided into two groups: analcime-bearing (tephritic lava flows and dykes) and analcime-free (basaltic to trachytic lava flows and basaltic dykes). The analcime-bearing volcanic rocks have a fine-grained porphyritic texture with clinopyroxene phenocrysts, whereas analcime-free volcanic rocks show a variety of textures including hyalo-microlitic microgranular porphyritic, intersertal, trachytic, fluidal and glomeroporphyritic. The volcanic rocks also show evidence of mineral-melt disequilibrium textures such as sieved, rounded and corroded plagioclases, partially melted and dissolved clinopyroxenes and poikilitic texture. Petrochemically, the parental magmas of the volcanic rocks evolved from alkaline to calc-alkaline lava suites and include high-K and shoshonitic compositions. They display enrichments in light rare earth and large ion lithophile elements such as $\mathrm{Sr}, \mathrm{K}$ and $\mathrm{Rb}$, as well as depletions in high field strength elements such as $\mathrm{Nb}, \mathrm{Ta}, \mathrm{Zr}$ and $\mathrm{Ti}$, resembling subduction-related magmas. The analcime-bearing and -free volcanic rocks share similar incompatible element ratios and chondrite-normalised rare rearth element patterns, indicating that they originated from similar sources.
\end{abstract} They also have relatively low to moderate initial ${ }^{87} \mathrm{Sr} /{ }^{86} \mathrm{Sr}(0.7042$ to 0.7051$)$, high positive $\varepsilon \mathrm{Nd}_{(\mathrm{t})}$ values $(+0.20$ to +3.32$)$, and depleted mantle $\mathrm{Nd}$ model ages $\left(T_{\mathrm{DM} 1}=0.63-0.93 \mathrm{Ga}, T_{\mathrm{DM} 2}=0.58-0.84 \mathrm{Ga}\right)$. The bulk-rock chemical and $\mathrm{Sr}-\mathrm{Nd}$ isotope features as well as the high $\mathrm{Rb} / \mathrm{Y}$ and $\mathrm{Th} / \mathrm{Zr}$, but low $\mathrm{Nb} / \mathrm{Zr}$ and $\mathrm{Nb} / \mathrm{Y}$ ratios, indicate that the volcanic rocks were derived from a lithospheric mantle source that had been metasomatised by slab-derived fluids. Trace element modelling suggests that the parental magma(s) of the volcanic rocks represent mixtures of melts derived by low-degree $(\sim 5-10 \%)$ partial melting of spinel-lherzolite $(40-85 \%)$ and garnet- 
lherzolite (15-60\%) mantle sources. Sr-Nd isotopic modelling also suggests that a $25-35 \%$ lower crustal component was added in the parental magmas; AFC modelling additionally indicates minor upper crustal contamination during the evolution of the volcanic rocks. In conclusion, integration of the geochemical, petrologic and isotopic data with regional geology suggests that the analcime-bearing and -free volcanic rocks evolved from parental magma(s) derived from melts of a subcontinental lithospheric mantle and lower crustal sources.

Keywords: analcime-bearing volcanics; mantle metasomatism; ${ }^{40} \mathrm{Ar-}{ }^{39}$ Ar geochronology; isotope geochemistry; Bafra (Samsun); Eastern Pontides

\section{Introduction}

Potassic volcanic rocks commonly occur in extensional tectonic settings and provide information on post-collisional or intraplate extensional magmatic processes within the continental lithosphere (e.g., Conticelli et al., 2009; Foley et al., 1987; Prelević et al., 2008, 2010, 2013, 2015), and are viewed as an essential agency for revealing mantle structure and chemical heterogeneities (Foley and Peccerillo, 1992). Despite their significance, the petrogenesis of potassic volcanic rocks has not been well constrained. It is generally considered that potassic volcanic rocks are derived from partial melting of an enriched mantle source (e.g., Foley et al., 1987) and mixing between mantle and crust-derived melts (e.g., Guo et al., 2013). However, there is controversy around which processes cause the mantle enrichment (Foley and Peccerillo, 1992). Metasomatism of melts (or fluids) derived from either subducted sediments (e.g., Prelević et al., 2010) or altered oceanic crust (e.g., Gaffney et al., 2007) has been proposed. Nevertheless, identification of the metasomatic material from various derivations is quite difficult (Prelević et al., 2010).

Cenozoic post-collisional potassic volcanic rocks are widespread throughout the vast Alpine-Himalayan orogenic belt that extends from the western Mediterranean to eastern Tibet (e.g., Conticelli and Peccerillo, 1992; Conticelli et al., 2009; Prelević et al., 2008, 2010, 2013, 2015). Western Mediterranean potassic rocks are intimately associated in space and time with shoshonite and in some cases to high-K calc-alkaline suites: this association occurs in the Western Alps, Tuscan and Roman Provinces (Central Italy), but also in Murcia-Almeria (south-eastern Spain), Macedonia, Serbia, Montenegro, and western Turkey (e.g., Conticelli et al., 2009; Prelević et al., 2008, 2010, 2013, 2015).

The Pontides in N Turkey (Fig. 1a), a part of the Alpine-Himalayan orogenic belt, form one of the most complex geodynamic settings, rising steeply inland from the Black Sea Coast. Palaeogene and Neogene post- 
collisional magmatism became voluminous in the Pontides, and now is an excellent example of the orogenic magmatism in the Alpine-Himalayan orogenic belt. The Middle Eocene volcanism, narrow along IAES in the Western-Central Pontides but widespread away from IAES in the Eastern Pontides (Fig. 1), was a result of the complex interplay between extensional tectonics and mantle dynamics, and provides a unique opportunity to understand the fingerprint of the mantle source beneath the orogenic belt. However, the Pontides' Palaeogene and Neogene volcanic rocks display great diversity, the source of which, even today, is still one of the most debated subjects in volcanic petrogenesis. Over the past decade, a consensus has been reached, that these volcanic rocks were typically generated during periods of heat and/or mass transfer from the mantle to the crust, either by partial melting of crustal rocks or by fractional crystallisation (FC) or assimilation combined with fractional crystallisation (AFC) of mantle-derived basaltic magmas (Arslan and Aliyazıcıŏlu, 2001; Arslan et al., 1997, 2013; Keskin et al., 2008; Temizel and Arslan, 2008, 2009; Temizel et al., 2012). Nevertheless, the evidence for direct contribution of mantle-derived magmas to production of these volcanic rocks is often circumstantial.

In this study, we present detailed mineral chemistry, ${ }^{40} \mathrm{Ar}-{ }^{39} \mathrm{Ar}$ dating, whole-rock and $\mathrm{Sr}-\mathrm{Nd}$ isotope geochemistry data of the Eocene-aged volcanic rocks around the Bafra (Samsun, N Turkey) area (Figs. 1a and b) to (1) better characterise the diversity of geochemistry in the volcanic rocks using extensive major, trace element and $\mathrm{Sr}-\mathrm{Nd}$ isotope datasets; (2) use these data in an attempt to constrain the mineralogy and composition of the possible nature of the parental magma(s) and mantle-crust source(s) of these volcanic rocks and to identify the materials and petrological processes (i.e. fractional crystallisation, assimilation) responsible for their evolution; and (3) ascertain conditions of melting and genetic relationships between the different volcanic rock suites. In addition, we performed a comprehensive evolutionary petrogenetic model that is representative of the entire volcanic history for Eocene-aged volcanism.

\section{Regional geological setting}

Turkey comprises three main tectonic units with distinct stratigraphic and structural features, which are the Anatolide-Tauride block, Central Anatolian Crystalline Complex and the Sakarya zone, which includes the Istanbul zone and the Central-Eastern Pontides (Fig. 1a; Okay and Tüysüz, 1999). The three main tectonic units are bounded by major oceanic suture zones, including the Izmir-Ankara-Erzincan Suture zone (IAEZ), the IntraPontide Suture zone, the Inner-Tauride Suture zone, and the Assyrian-Zagros Suture zone. The Pontides of northern Turkey were formed as a consequence of northward subduction of the Neotethys Ocean along the 
Eurasian Margin during Mesozoic times, and was followed by final collision with the Anatolides-Taurides platform during Cenozoic times (e.g., Arslan et al., 1997, 2013; Okay and Şahintürk, 1997; Şengör and Y1lmaz, 1981).

The basement of the Eastern Pontides consists of metamorphic rocks, probably of DevonianCarboniferous age, which are crosscut by Permo-Carboniferous plutons (e.g., Kaygusuz et al., 2012; Okay and Şahintürk, 1997; Topuz et al., 2010). Early and Middle Jurassic volcanic and volcaniclastic rocks lie unconformably on a Palaeozoic basement and mostly crop out in the south. Jurassic volcanic rocks, which are mainly tholeiitic in character, comprise basaltic, minor andesitic, and trachyandesitic lavas and their pyroclastic equivalents, developed within an extensional setting, possibly related to rifting and consistent with the general geochemical characteristics of a volcanic arc setting (e.g., Arslan et al., 1997; Şen, 2007). Early and Middle Jurassic volcanic and volcaniclastics are conformably overlain by Middle-Late Jurassic-Cretaceous neritic and pelagic carbonates (Okay and Şahintürk, 1997). The Late Cretaceous series that unconformably overlie these carbonate rocks consist of sedimentary rocks in the south and volcanic rocks in the north (e.g., Robinson et al., 1995). The Late Cretaceous volcanic rocks consist of tholeiitic to calc-alkaline dacite, rhyolite, and less andesite, basalt, and their pyroclastics. These units are intruded by Upper Cretaceous and Palaeocene granitoids (Kaygusuz et al. 2009, 2010; Okay and Şahintürk, 1997; Y1lmaz et al., 1997). The Eocene volcanic and volcaniclastic rocks are widespread and mainly unconformably overlie Late Cretaceous volcanic and/or sedimentary series (Arslan and Aliyazıŏlu, 2001; Arslan et al., 2013; Aslan et al., 2014; Güven, 1993; Kaygusuz et al., 2011; Temizel et al., 2012). From Palaeocene to Early Eocene times, the region was above sea level, probably due to the collision between the Pontides magmatic arc and the Tauride-Anatolide Platform (Okay and Şahintürk, 1997).

Middle Eocene volcanic and sedimentary units are exposed widely between the Hamamözü (Amasya) area in the Central Pontides and the Artvin area in the Eastern Pontides, as reported in the Hamamözü (Keskin et al., 2008), Ordu (Temizel and Arslan, 2008, 2009; Temizel et al., 2012), Gümüşhane (Arslan and Aliyazıcıŏ̆lu, 2001; Arslan et al., 2013; Aslan et al., 2014; Kaygusuz et al., 2006, 2011), Trabzon (Yücel et al., 2014a), Bayburt (Arslan et al., 2013) and Artvin (Aydınçakır and Şen, 2013) areas (Fig. 1b). In the north of the Eastern Pontides, post-collisional Middle Eocene to Miocene volcanic and volcaniclastic rocks with coeval granitoids crop out in restricted areas (Arslan et al., 1997; Aydın et al., 2008; Şen et al., 1998; Yücel et al., 2014a). However, Palaeogene and Neogene magmatic activity in the south of the Eastern Pontides is restricted to postcollisional Middle Eocene volcanic rocks, from basaltic to dacitic rocks of calc-alkaline to tholeiitic affinities 
(e.g., Arslan and Aliyazıcıŏ̆lu, 2001; Arslan et al., 1997, 2013; Aslan et al., 2014; Aydınçakır and Şen, 2013; Kaygusuz et al., 2011; Temizel and Arslan, 2008, 2009; Temizel et al., 2012) and granitoids (e.g., Arslan and Aslan, 2006; Kaygusuz and Öztürk, 2015; Temizel, 2014; Temizel et al., 2014), apart from Palaeocene plagioleucitites (Altherr et al., 2008) and Early Eocene adakite-like granitic (Topuz et al., 2011) and andesiticdacitic rocks (Karslı et al., 2010; Eyüboğlu et al., 2011). During Late Eocene times, the region remained largely above sea level, with minor volcanism and terrigeneous sedimentation that have continued to the present (Okay and Şahintürk, 1997). The Miocene volcanic history of the Eastern Pontides is characterised by alkaline volcanism, which is mainly reported in the north, along the Black Sea Coast, the Trabzon area (Şen et al., 1998; Arslan et al., 2001; Aydın et al., 2008; Yücel et al., 2014a), and the Ulubey (Ordu) area (Temizel et al., 2012).

\section{Local geology and stratigraphy}

The study area is located in (Bafra) Samsun, in the northwestern edge of the Eastern Pontides, northern Turkey (Figs. 1a and 1b). The oldest unit in the studied area is the Late Cretaceous-aged Cankurtaran formation (e.g., Görür and Tüysüz, 1997), which consists of tuff-tuffite, sandy limestone, and marl intercalated with sandstone and shale alternations (Fig. 2). This unit is overlain conformably by the Late Cretaceous-Late Palaeocene-aged Akveren Formation (Görür and Tüysüz, 1997) composed of reddish mainly massive-rarely medium-thick bedded sandstone; greyish, whitish sandy limestone; greyish medium bedded limestone; greyish medium-bedded marl including a large amount of foraminifera; reddish, purplish siltstone, and shale intercalations. The Late Palaeocene-Early Eocene-aged Atbaşı Formation (e.g., Gedik et al., 1984) conformably overlies these units and consists of beige thin-medium bedded limestone, red sandy limestone, grey and redpurple thin-bedded sandstone, and purple thick-bedded marl intercalations. These units are overlain unconformably by the Early to Middle Eocene-aged Kusuri Formation (Görür and Tüysüz, 1997) composed of greyish limestone interbedded with yellowish-grey thin-medium-bedded sandstone and dark-greyish mediumthick-bedded marl alternations. The Middle Eocene-aged basaltic-trachytic lava flows, dykes and pyroclastics intercalated with locally mudstone, siltstone, limestone and marl, conformably overlie these units. Stratigraphically, this unit has been previously reported as the Middle-Late Eocene-aged Tekkeköy Formation (e.g., Gedik et al., 1984). These units overlie the Middle Eocene-aged tephritic lava flows and pyroclastics, and are cross-cut by tephritic dykes and monzogabbros (Fig. 2). Stratigraphically, this unit has been previously reported as Late Miocene-Pliocene-aged Mahmurdağ volcanics (e.g., Gedik et al. 1984). However, the obtained ${ }^{40} \mathrm{Ar}-{ }^{39} \mathrm{Ar}$ ages from the lava flows, dykes and monzogabbros in this study are not in accordance with the 
previously indicated Late Miocene-Pliocene age. Besides, Temizel (2014) and Temizel et al. (2014) reported mineral chemistry, thermobarometry, emplacement conditions, whole-rock petrochemical features and $\mathrm{Sr}-\mathrm{Nd}$ isotope geochemistry (except for Ar-Ar dating) of the monzogabbroic stocks in the area. All these units are overlain unconformably by Quaternary old alluvium and terrace deposits and alluvium (see Fig. 2).

\section{Analytical methods}

About 75 samples from lava flows and dykes of the Bafra (Samsun) area volcanic rocks were examined under a polarised microscope to determine mineralogical composition and textural-petrographic properties. Based on the petrographical studies, fresh and most representative rock samples were analysed for mineral chemistry, whole-rock major, trace-, and rare-earth-element, $\mathrm{Sr}-\mathrm{Nd}$ isotopic compositions and ${ }^{40} \mathrm{Ar}-{ }^{39} \mathrm{Ar}$ dating.

Mineral chemistry analyses of common pheno- and microphenocrysts on the selected volcanic rock samples (see Electronic Supplementary Material-I (ESM-I), Appendices 1-6) were performed on carbon-coated polished sections using a JEOL JXA-8900RL electron microprobe at Tübingen University (Germany). The major element composition of feldspar, clinopyroxene, amphibole, olivine, and Fe-Ti oxide was analysed with an accelerating voltage of $15 \mathrm{kV}$ and sample current of $15 \mathrm{nA}$. Peak and background counting times ranged from 10-20 s and 5-10 s, respectively.

${ }^{40} \mathrm{Ar}-{ }^{39} \mathrm{Ar}$ ages of the studied rocks were measured by the step-heating experimental method, which has been described in detail by Ruffet et al. (1995, 1997). The step-heating analyses (Electronic Supplementary Material-II, ESM-II) of the selected volcanic rocks (single whole-rock fragments) and monzogabbroic stock (whole-rock fragment and biotite single grain) samples were carried out by an ${ }^{40} \mathrm{Ar}-{ }^{39} \mathrm{Ar}$ laser probe $\left(\mathrm{CO}_{2}\right.$ Synrad $^{\circledR}$ ) at Géosciences Rennes (France) (Table 1). Whole-rock fragments and biotite grains were carefully handpicked under a binocular microscope from crushed rocks (0.3-2 mm fraction). The samples were wrapped in aluminum foil to form packages $(11 \mathrm{~mm} \times 11 \mathrm{~mm} \times 0.5 \mathrm{~mm})$. These packages were stacked up to form a pile, within which packages of flux monitors were inserted every 8-10 samples. The stack, placed in an irradiation can, was irradiated for 13.33 hours at the McMaster reactor (Hamilton, Canada) with a total flux of $1.7 \times 10^{18}$ n. $\mathrm{cm}^{-2}$. The sample arrangement allowed us to monitor the flux gradient with a precision of $\pm 0.2 \%$. Blanks are performed routinely every first or third run, and are subtracted from the subsequent sample gas fractions. Analyses are performed on a Map215 ${ }^{\circledR}$ mass spectrometer. To define a plateau age, a minimum of three consecutive steps are required, corresponding to a minimum of $70 \%$ of the total ${ }^{39} \mathrm{Ar}_{\mathrm{K}}$ released, and the individual fraction ages should agree to within $1 \sigma$ or $2 \sigma$ of the integrated age of the plateau segment. Pseudo- 
plateau ages, with less than $70 \%$ of ${ }^{39} \mathrm{Ar}_{\mathrm{K}}$ released, can also be defined. All presented and discussed ${ }^{40} \mathrm{Ar}-{ }^{39} \mathrm{Ar}$ results are displayed at the $1 \sigma$ level.

Whole-rock major, trace and rare earth element (REE) compositions of the representative volcanic rock samples were analysed at ACME Analytical Laboratories Ltd. (Vancouver, Canada). The volcanic rock samples were crushed into small chips $(0.1-1 \mathrm{~cm}$ in diameter) using a jaw crusher and then pulverised using a mild-steel mill. Major oxides and trace elements were determined by inductively coupled with plasma-atomic emission spectrometry (ICP-AES) from pulp after $0.2 \mathrm{~g}$ of rock powder was fused with $1.5 \mathrm{~g} \mathrm{LiBO}_{2}$ and then dissolved in $100 \mathrm{~mL}$ of $5 \% \mathrm{HNO}_{3}$. REE contents were analysed by inductively coupled with plasma-mass spectrometry (ICPMS) after $0.25 \mathrm{~g}$ rock powder was dissolved during multiple acid digestion steps. Loss on ignition (LOI) was determined based on weight difference after ignition of samples at $\sim 1000{ }^{\circ} \mathrm{C}$. Detection limits vary from $0.002-$ $0.04 \mathrm{wt} \%$ for major oxides, $0.1-8 \mathrm{ppm}$ for trace elements, and 0.01-0.3 ppm for REEs (Table 2).

$\mathrm{Sr}$ and $\mathrm{Nd}$ isotopic compositions of the selected volcanic rock samples were performed at the Pacific Centre for Isotopic and Geochemical Research (PCIGR) of the University of British Columbia (Canada). For isotopic analysis, the samples were repeatedly leached with $\mathrm{HCl6N}$ to remove secondary alteration. $\mathrm{Sr}$ and $\mathrm{Nd}$ were separated using the method described by Weis et al. (2006). Isotope ratios were measured by a Thermo Finnigan Triton Thermal Ionization Mass Spectrometry (TIMS) in static mode with relay matrix rotation on single Ta filament and double Re-Ta filament for Sr and Nd isotopic analyses, respectively. During the analyses, the NBS987 Sr standard showed an average of $0.710240 \pm 0.000013$, and the La Jolla Nd standard showed an average value of $0.511857 \pm 0.000017$.

\section{Petrography and mineral chemistry}

Based on the modal mineralogical differences, the studied Eocene lava flows and dykes (excluding pyroclastics) in the Bafra area can be divided into analcime-bearing and analcime-free volcanic rocks. The analcime-bearing ones are composed of tephritic lava flows and dykes, whereas the analcime-free ones consist of basaltic to trachytic lava flows and basaltic dykes.

\subsection{Basaltic-trachytic lava flows and dykes}

The samples of lava flows show hyalo-microlitic porphyritic, microgranular porphyritic and sieve textures in basaltic rocks, and microlitic porphyric, trachytic and glomeroporphyric textures in trachytic rocks. The modal mineralogy of basaltic rocks is dominated by plagioclase, clinopyroxene, hornblende and/or olivine 
phenocrysts and Fe-Ti oxides in a fine-grained glassy groundmass of the same components, as well as secondary calcite and zeolite. Besides, trachytic rocks consist of plagioclase, clinopyroxene, sanidine with minor amount of biotite, apatite and Fe-Ti oxides. Generally, plagioclase phenocrysts are fresh and exhibit albite twinning, sieve texture and oscillatory zoning. The plagioclase compositions range from $\mathrm{An}_{48}$ to $\mathrm{An}_{91}$ as labradorite and bytownite in the basaltic to trachytic samples (Deer et al., 1992; Fig. 3a; Appendix A1, ESM-I). The sanidine phenocrysts $(2.5 \mathrm{~mm} \times 0.5 \mathrm{~mm})$ in the trachytic samples occur as mainly subhedral laths, and form a poikilitic texture with numerous subhedral clinopyroxene, plagioclase and Fe-Ti oxide. The sanidine compositions of the trachytic samples range from $\mathrm{An}_{2} \mathrm{Ab}_{24} \mathrm{Or}_{58}$ to $\mathrm{An}_{4} \mathrm{Ab}_{39} \mathrm{Or}_{74}$ as sanidine (Fig. 3a; Appendix A2, ESM-I) in the classification of Deer et al. (1992). Clinopyroxenes, mainly euhedral to subhedral crystals, in part clustered in a glomeroporphyric texture, are salite $\left(\mathrm{Wo}_{45} \mathrm{En}_{33} \mathrm{Fs}_{11}\right.$ to $\left.\mathrm{Wo}_{51} \mathrm{En}_{42} \mathrm{Fs}_{18}\right)$ in composition (Morimoto et al., 1988; Fig. 3b; Appendix A3, ESM-I). Several phenocrysts are rounded, irregular, broken, unzoned or weakly zoned and often include Fe-Ti oxide and plagioclase inclusions. The olivines in the basaltic samples are chrysolite and hyalosiderite $\left(\mathrm{Fo}_{67-76}\right)$ in composition (Fig. 3c, Appendix A5, ESM-I), and are euhedral to subhedral, fractured and extensively iddingsitised. The hornblendes in the basaltic samples occur as subhedral grains and are classified (Leake et al., 1997) into pargasite $(\mathrm{Mg \#}=0.58-0.87$, Fig. 3d; Appendix A4, ESM-I). The apatite has a typical acicular shape, and occurs in clots as stubby grains of about $0.5 \mathrm{~mm}$, and is occasionally included in clinopyroxene and plagioclase. Fe-Ti oxides are magnetite in composition (Bacon and Hirschmann, 1988; Fig. 3e; Appendix A6, ESM-I) with abundant subhedral grains in the basaltic and trachytic rocks.

The samples from the basaltic dykes are composed of plagioclase, less abundant clinopyroxene and FeTi oxides embedded in an intersertal groundmass including plagioclase, clinopyroxene and Fe-Ti oxides with minor glass. One dyke has abundant plagioclase phenocrysts (50\%) with doleritic texture, whereas several are aphyric. Plagioclases often form crystal clots of several crystals exhibiting polysynthetic and albite twinning. Some phenocrysts also exhibit oscillatory to complex zoning and sieve texture. The plagioclase compoitions of the basaltic dyke samples range from $\mathrm{An}_{37}$ to $\mathrm{An}_{91}$ as andesine to anorthite (Fig. 3a; Appendix A1, ESM-I) in the classification of Deer et al. (1992). Clinopyroxene phenocrysts are mainly euhedral prismatic crystals up to $1 \mathrm{~cm}$ in size with scarce subhedral grains in doleritic texture, whereas the microphenocrysts are rounded, irregular and broken crystals in an intersertal groundmass. Clinopyroxenes range from $\mathrm{Wo}_{46} \mathrm{En}_{26} \mathrm{Fs}_{12}$ to $\mathrm{Wo}_{52} \mathrm{En}_{39} \mathrm{Fs}_{22}$ as salite and fassaite in composition (Morimoto et al., 1988; Fig. 3b; Appendix A3, ESM-I). Fe-Ti oxides are abundant subhedral grains, present mainly in association with mafic minerals in the glassy groundmass and are magnetite in composition (Bacon and Hirschmann, 1988; Fig. 3e; Appendix A6, ESM-I). 


\subsection{Tephritic lava flows and dykes}

The lava flow samples consist mainly of clinopyroxene, plagioclase, analcime, Fe-Ti oxide and subordinate biotite phenocrysts in a glassy fine-grained groundmass of the same mineral components. Plagioclase phenocrysts, displaying polysynthetic and multiple twinning, also occur as subhedral to euhedral microphenocrysts in the glassy groundmass. The plagioclase compositions range from $\mathrm{An}_{71}$ to $\mathrm{An}_{90}$ as bytownite and anorthite in the lava flow samples (Deer et al., 1992; Fig. 3a; Appendix A1, ESM-I). Clinopyroxenes, mainly euhedral to subhedral crystals, are present both as phenocrysts and microphenocrysts. Clinopyroxenes range from $\mathrm{Wo}_{44} \mathrm{En}_{27} \mathrm{Fs}_{8}$ to $\mathrm{Wo}_{52} \mathrm{En}_{43} \mathrm{Fs}_{24}$ as salite and fassaite in composition (Morimoto et al., 1988; Fig. 3b, Appendix A3, ESM-I). They exhibit oscillatory, concentric and sector zoning, or are rounded, broken, embayed, and have signs of dissolution. Most of the clinopyroxene is surrounded by zeolite as overgrowth rims. Euhedral or anhedral analcime crystals (probably as a replacement of primary leucite; Yücel et al., 2014b) are set in a glassy groundmass as hexagonal or rounded shapes. Biotite occurs as small bladed, euhedral to subhedral redbrown grains. Red-brown bladed biotites $(0.2-0.5 \mathrm{~mm})$ are typically found around the clinopyroxene phenocrysts and Fe-Ti oxides. Fe-Ti oxides are subhedral grains present mainly in association with mafic minerals in the glassy groundmass and are magnetite in composition (Bacon and Hirschmann, 1988; Fig. 3e; Appendix A6, ESM-I).

The dyke samples present fine-grained porphyritic textures with phenocrysts, euhedral to subhedral clinopyroxene and plagioclase, plus to analcime microphenocrysts and Fe-Ti oxides set in a fine-grained to glassy groundmass made up of plagioclase laths in addition to granular to prismatic crystals of clinopyroxene, analcime and Fe-Ti oxides. Plagioclase phenocrysts are mainly represented by euhedral to subhedral crystals and are up to $1.5 \mathrm{~mm}$ in diameter. The plagioclase compositions range from $\mathrm{An}_{86}$ to $\mathrm{An}_{94}$ as bytownite and anorthite in the dyke samples (Deer et al., 1992; Fig. 3a; Appendix A1, ESM-I). They exhibit both albite and karlsbad twins; however, the latter are infrequent. Clinopyroxene phenocrysts are present as euhedral to slightly rounded prismatic crystals up to $0.5 \mathrm{~mm}$ in size and in places occur as crystal clots with plagioclase. Clinopyroxenes range from $\mathrm{Wo}_{50} \mathrm{En}_{26} \mathrm{Fs}_{12}$ to $\mathrm{Wo}_{53} \mathrm{En}_{39} \mathrm{Fs}_{24}$ as salite and fassaite in composition (Morimoto et al., 1988; Fig. 3b; Appendix A3, ESM-I). Some clinopyroxene crystals up to $2 \mathrm{~mm}$ in size have cores containing abundant melt, plagioclase and analcime inclusions, and have oscillatory zoning. Analcime (probably as a replacement of primary leucite; Yücel et al., 2014b) is present as rounded to unhedral equant crystals less than $0.2 \mathrm{~mm}$ in size. Some analcime crystals are present within crystal clots with clinopyroxene. Fe-Ti oxides are present mainly in 
association with mafic minerals and fine disseminations in the groundmass. Fe-Ti oxides are magnetite in composition (Bacon and Hirschmann, 1988; Fig. 3e; Appendix A6, ESM-I).

\section{6. ${ }^{40} \mathrm{Ar}-{ }^{39} \mathrm{Ar}$ dating}

${ }^{40} \mathrm{Ar}-{ }^{39} \mathrm{Ar}$ plateau ages range from $\sim 51-44 \mathrm{Ma}$ for the six volcanic rock samples, and from $\sim 45-44 \mathrm{Ma}$ for two monzogabbroic samples from the Bafra area (online ESM II). A summary of the ${ }^{40} \mathrm{Ar}-{ }^{39} \mathrm{Ar}$ age data on the single whole-rock fragments of the volcanic rock samples and biotite single grain/whole-rock fragment of the monzogabbroic samples is listed in Table 1, and age spectra are shown in Fig. 4. As seen in Fig. 4, all plateaus appear to be somewhat disturbed by minor alteration phases or post-crystallisation heating. However, all single whole-rock fragments from the volcanic rock samples (except samples B-3 and B-9) yielded meaningful plateau ages of $44.12 \pm 0.28 \mathrm{Ma}$ for the tephritic dyke, $51.38 \pm 0.21 \mathrm{Ma}$ and $44.79 \pm 0.20 \mathrm{Ma}$ for the tephritic lava flows, and $44.50 \pm 0.20 \mathrm{Ma}$ for the basaltic dyke (Fig. 4), corresponding to Early-Middle Eocene times (YpresianLutetian). Furthermore, the monzogabbroic stock samples produced meaningful plateau ages of $45.04 \pm 0.25 \mathrm{Ma}$ (biotite single grains) and $44.59 \pm 0.19$ Ma (single whole-rock fragments: Fig. 4), corresponding to Middle Eocene times (Lutetian). The obtained ${ }^{40} \mathrm{Ar}-{ }^{39} \mathrm{Ar}$ ages from the volcanic rocks and monzogabbros are not in accordance with the previously reported Late Miocene-Pliocene age as stratigraphically by Gedik et al. (1984). Single whole-rock fragments of a tephritic lava sample (B-3) and a trachytic lava sample (B-9) yielded an irregular, humped and/or flattened shaped age spectrum without a plateau age (Fig. 4). These two whole rock samples (B-3 and B-9) display decreasing apparent ages vs. step heating (except for the very first steps in B-3 and B-9). These shapes for age spectra are characteristic of whole rocks affected by ${ }^{39} \mathrm{Ar}$ recoil during irradiation, with loss of ${ }^{39} \mathrm{Ar}$ clearly shown by decreasing apparent ages towards high temperature steps (or high $\left.\%{ }^{39} \mathrm{Ar}_{\mathrm{K}}\right)$. The apparent ages of the tephritic lava sample B-3 are $46.98 \pm 0.28 \mathrm{Ma}$ for up to $60 \%$ of the gas released, but $46.48 \pm 0.24$ Ma for approximately $70 \%$ of the gas released. Apparent ages of the trachytic lava sample B-9 are $46.09 \pm 0.22$ Ma for up to $60 \%$ of the gas released, but $45.83 \pm 0.20$ Ma for approximately $70 \%$ of the gas released.

\section{Whole-rock geochemistry}

Whole-rock major oxide, trace and rare earth element analyses of the volcanic rock samples from the Bafra (Samsun) area are listed in Table 2. Based on the total alkalis vs. silica classification diagram (TAS) of Le Bas et al. (1986) (Fig. 5a), the volcanic rock samples have $\mathrm{SiO}_{2}$ contents in the range of 40-57 wt\% and show a 
trend of increasing $\mathrm{Na}_{2} \mathrm{O}+\mathrm{K}_{2} \mathrm{O}$ vs. $\mathrm{SiO}_{2}$. The samples from the tephritic lava flow and tephritic dyke all plot in the tephrite/basanite field. Due to their low olivine contents (normative olivine: $2.79-10.87 \%$ except for sample B3; Table 3), they can all be classified as tephrites (Le Bas et al., 1986). The basaltic-trachytic lava flow samples span a wide range of compositions from basalt to trachyandesite through to trachybasalt and basaltictrachyandesite, while the basaltic dyke samples scatter mainly on the field of trachybasalt composition, with one sample on the boundary between trachybasalt and basanite/tephrite fields (Fig. 5a). On the basis of the TAS diagram, almost all volcanic rock samples have alkaline compositions (Fig. 5a) with high alkalinity index $\left(\left(\mathrm{Na}_{2} \mathrm{O}+\mathrm{K}_{2} \mathrm{O}\right)-\left(0.37 \times \mathrm{SiO}_{2}-14.43\right)\right)$ from +0.96 to +4.35 (Table 2$)$. On the basis of the $\mathrm{K}_{2} \mathrm{O}$ vs. $\mathrm{SiO}_{2}$ diagram (Fig. $5 b)$, the majority of samples from the volcanic rocks are high-K to shoshonitic in composition. Besides, the volcanic rock samples $(\mathrm{MgO}>3 \mathrm{wt} \%)$ plot mainly in the high-K/shoshonitic field, with a few samples on the boundary between calc-alkaline and high-K/shoshonitic fields on the Th vs. Co (Fig. 5c) classification diagram of Hastie et al. (2007). On the $\Delta \mathrm{Q}$ vs. $\mathrm{K}_{2} \mathrm{O} / \mathrm{Na}_{2} \mathrm{O}$ (Fig. 5d) discrimination diagram of Peccerillo (2005), all samples also show silica undersaturated $(\Delta \mathrm{Q}<0)$ calc-alkaline to shoshonitic features.

The variation of some major and trace elements with $\mathrm{SiO}_{2}$ for the studied volcanic rocks (Fig. 6) pointed out two clusters probably related to separate magmatic phases; (1) the analcime-bearing volcanic rocks (tephritic lava flow and tephritic dyke, $\mathrm{SiO}_{2}<44.9 \mathrm{wt} \%$ ), and (2) analcime-free volcanic rocks (basaltic-trachytic lava flow and basaltic dyke, $\left.\mathrm{SiO}_{2}>45.6 \mathrm{wt} \%\right)$. Although the $\mathrm{MgO}, \mathrm{MnO}, \mathrm{CaO}, \mathrm{Fe}_{2} \mathrm{O}_{3}(\mathrm{t}), \mathrm{P}_{2} \mathrm{O}_{5}$ and $\mathrm{TiO}_{2}$ contents of the analcime-bearing samples are higher than those of the analcime-free samples, the $\mathrm{Na}_{2} \mathrm{O}$ and $\mathrm{Al}_{2} \mathrm{O}_{3}$ contents of all rock samples are similar. However, the analcime-free samples have higher $\mathrm{K}_{2} \mathrm{O}$ contents than the analcime-bearing samples (Table 2).

As a function of $\mathrm{SiO}_{2}$ content, the variations of major and trace element (Fig. 6) display well-defined negative, weak negative or positive correlations, reflecting the significant effect of fractional crystallisation processes of different mineral phases during the evolution of the studied volcanic rocks. An increase in the $\mathrm{SiO}_{2}$ $(<44.9 \mathrm{wt} \%)$ contents of analcime-bearing samples shows a decrease in $\mathrm{TiO}_{2}, \mathrm{Fe}_{2} \mathrm{O}_{3}(\mathrm{t}), \mathrm{MnO}$ and $\mathrm{CaO}$ contents and an increase in $\mathrm{Al}_{2} \mathrm{O}_{3}, \mathrm{Na}_{2} \mathrm{O}, \mathrm{Ba}, \mathrm{Zr}$ and $\mathrm{Nb}$ contents (Fig. 6). There is a decrease for $\mathrm{TiO}_{2}, \mathrm{Fe}_{2} \mathrm{O}_{3}(\mathrm{t}), \mathrm{CaO}$, $\mathrm{MnO}, \mathrm{MgO}$ and $\mathrm{P}_{2} \mathrm{O}_{5}$ contents, whereas an increase for $\mathrm{Al}_{2} \mathrm{O}_{3}, \mathrm{~K}_{2} \mathrm{O}, \mathrm{Na}_{2} \mathrm{O}$, Th, $\mathrm{Rb}, \mathrm{Ba}, \mathrm{Zr}$ and Nb contents with increasing $\mathrm{SiO}_{2}(>45.6 \mathrm{wt} \%$ ) in analcime-free samples (Fig. 6). Also, Sr (except for sample B-25) exhibits a weak negative correlation with increasing $\mathrm{SiO}_{2}$ in the analcime-free lava samples.

In primitive mantle-normalised (Sun and McDonough, 1989) multi-element spider diagrams (Fig. 7a-d), volcanic rocks exhibit similar enrichment in the large-ion lithophile elements (LILEs) including $\mathrm{Sr}, \mathrm{K}_{2} \mathrm{O}$ and $\mathrm{Rb}$, 
and depletions in several high field strength elements (HFSEs) such as $\mathrm{Nb}, \mathrm{Ta}, \mathrm{Zr}$ and $\mathrm{TiO}_{2}$. All these geochemical features are characteristic of subduction-related magmatism (e.g., Pearce, 1983). In addition, fluidmobile elements (e.g., Ba) are notably enriched relative to the melt-mobile elements such as Th. The relative enrichment of $\mathrm{Ba}$ indicates the involvement of fluids released from the subducted slab, because $\mathrm{Ba}$ is the most mobile element in such fluids (Xiaoming et al., 2007, and references therein).

Chondrite-normalised (Taylor and McLennan, 1985) REE patterns of the studied rocks (Fig. 7e-h) are enriched in light REEs (LREEs) relative to heavy REEs (HREEs). Both analcime-bearing and -free rock samples exhibit moderately fractionated, chondrite-normalised REE patterns $\left(\mathrm{La}_{\mathrm{N}} / \mathrm{Yb}_{\mathrm{N}}=5.2-6.9,4.7-7.8,4.9-7.4\right.$ and 5.7-8.6, respectively) parallel to each other. REE distributions have smooth slope patterns, which tend to flatten toward LREEs and HREEs, and exhibit slight or no Eu anomalies $\left(\mathrm{Eu}_{\mathrm{N}} / \mathrm{Eu}^{*}\right)$, ranging from $0.78-0.97$ with an average of 0.88 (Fig. 7e-h). This suggests either sufficiently high oxygen fugacities such that Eu is trivalent and hence does not enter the plagioclase structure, or negligible fractionation of plagioclase, which is in keeping with the lack of plagioclase in the phenocryst assemblage.

\section{Sr- and Nd- isotope geochemistry}

Sr-Nd isotopic compositions of seven samples for the Bafra (Samsun) volcanic rocks are reported in Table 4 and the initial ratios are plotted in Fig. 8. The initial ${ }^{87} \mathrm{Sr} /{ }^{86} \mathrm{Sr}$ and ${ }^{143} \mathrm{Nd} /{ }^{144} \mathrm{Nd}$ ratios, and $\varepsilon \mathrm{Nd}_{(\mathrm{t})}$ values have been calculated on the basis of the whole-rock ${ }^{40} \mathrm{Ar}-{ }^{39} \mathrm{Ar}$ plateau ages for these rocks (Fig. 8). The tephritic dyke sample has slightly higher initial (calculated at $44 \mathrm{Ma}{ }^{87} \mathrm{Sr} /{ }^{86} \mathrm{Sr}$ of 0.70510 and slightly lower initial ${ }^{143} \mathrm{Nd} /{ }^{144} \mathrm{Nd}(0.512627)$ ratios corresponding to positive $\varepsilon \mathrm{Nd}_{(\mathrm{t})}$ value of 0.89 than the other samples (Fig. 8). The tephritic lava flow samples have a narrow range of isotope compositions with initial (calculated at 44-51 Ma) ${ }^{87} \mathrm{Sr} /{ }^{86} \mathrm{Sr}$ ranging from $0.70482-0.70487$ and initial ${ }^{143} \mathrm{Nd} /{ }^{144} \mathrm{Nd}(0.51265-0.51267)$ ratios corresponding to positive $\varepsilon \mathrm{Nd}_{(\mathrm{t})}$ values between $1.56-1.83$ (Fig. 8). The basaltic dyke sample has initial (calculated at $46 \mathrm{Ma}$ ) ${ }^{87} \mathrm{Sr} /{ }^{86} \mathrm{Sr}$ of 0.70513 and initial ${ }^{143} \mathrm{Nd} /{ }^{144} \mathrm{Nd}(0.51259)$ ratios corresponding to positive $\varepsilon \mathrm{Nd}_{(\mathrm{t})}$ value of 0.20 (Fig. 8). The trachytic lava flow samples have a narrow range of isotope compositions with initial (calculated at 46 Ma) ${ }^{87} \mathrm{Sr} /{ }^{86} \mathrm{Sr}$ ranging from $0.70424-0.70486$ and initial ${ }^{143} \mathrm{Nd} /{ }^{144} \mathrm{Nd}(0.51266-0.51275)$ ratios corresponding to positive $\varepsilon \mathrm{Nd}_{(\mathrm{t})}$ values between $1.50-3.32$ (Fig. 8). The corresponding single-stage and two-stage depleted mantle Nd model ages ( $T_{\mathrm{DM} 1}$ and $T_{\mathrm{DM} 2}$, respectively) of the studied volcanic rocks are in the range $0.63-0.93 \mathrm{Ga}$ and 0.58-0.84 Ga, respectively. These single-stage depleted mantle $\mathrm{Nd}$ model $\left(\mathrm{T}_{\mathrm{DM} 1}\right)$ ages suggest that the lithospheric mantle source for the studied volcanic rocks is Proterozoic $(0.58 \mathrm{Ga}$ to $0.93 \mathrm{Ga})$ in age, similar to 
other post-collisional Eocene volcanic rocks in the Eastern Pontides (e.g., Arslan et al., 2013; Aslan et al., 2014; Temizel et al., 2012) and K-enriched subcontinental lithospheric mantle (SCLM) source of post-collisional volcanic rocks in Western Anatolia (e.g., Altunkaynak, 2007; Dilek and Altunkaynak, 2010). As illustrated in Fig. 8, the studied rocks plot in the partly depleted and partly enriched quadrants of a conventional $\mathrm{Sr}$ vs. Nd isotope diagram, where they partly overlap the fields defined by the Middle Miocene-aged volcanic rocks (Aslan et al. 2014; Temizel et al., 2012), Middle Eocene-aged monzogabbro (Temizel et al., 2012), Middle Eocene-aged volcanic rocks (Arslan et al., 2013, Aslan et al., 2014; Kaygusuz et al., 2011; Temizel et al., 2012), Middle Eocene-aged granitoids (Karslı et al., 2012) and Early Eocene-aged adakitic porphyries and granitoids (Eyüboğlu et al., 2011; Topuz et al., 2011) from the Eastern Pontides.

\section{Discussion}

Primitive mantle-normalised trace element and chondrite-normalised REE patterns of the analcimebearing rock samples (tephritic lava flows and dykes) largely overlap those of the analcime-free rock samples (basaltic-trachytic lava flows and dykes) from the Bafra (Samsun) area (see Fig. 7), as do their major element data. This might be considered as implying the petrogenetic link between analcime-bearing and -free volcanic rocks. Therefore, different scenarios including source characteristics and mantle mineralogy, fractional crystallisation, assimilation-fractional crystallisation, and different degrees of mantle metasomatism are discussed to evaluate the possibility of a petrogenetic link between these two group rocks.

\subsection{Source characteristics and primary melts}

Primitive mantle-normalised spider diagrams (see Fig. 7a-d) of the studied volcanic rocks suggest similar magma source(s) for the studied rocks. Furthermore, the crustal elemental systematics, as suggested by LILEs and LREEs enrichments and associated $\mathrm{Nb}-\mathrm{Ta}, \mathrm{Zr}-\mathrm{Hf}$ and $\mathrm{Ti}$ depletions in the studied rocks, cannot be explained by crystallisation fractionation alone. Depletion of Nb-Ta relative to LILEs (e.g. $\mathrm{Sr}, \mathrm{K}_{2} \mathrm{O}, \mathrm{Rb}$ and $\mathrm{Ba}$ ) can be attributed to subduction-related metasomatism, possibly due to HFSEs being retained in the subduction slab during progressive dehydration, whereas the LILEs and LREEs are transported upward by slab-derived fluid or melts fertilising the overlying mantle wedge (e.g., Zellmer et al., 2005). Trace element features of the studied volcanic rocks favour a subduction-modified SCLM source (e.g., Münker et al., 2004). Moreover, the Sr and Nd isotopic compositions for the volcanic rocks are relatively homogeneous in isotopic composition, with $\left({ }^{87} \mathrm{Sr} /{ }^{86} \mathrm{Sr}\right)_{\mathrm{i}}$ ranging from $0.70424-0.70513,\left({ }^{143} \mathrm{Nd} /{ }^{144} \mathrm{Nd}\right)_{\mathrm{i}}$ from $0.51259-0.51275$, and $\varepsilon \mathrm{Nd}_{(\mathrm{i})}$ from $(+0.20)$ to 
(+3.32). These volcanic rocks present a narrow range in $\left({ }^{87} \mathrm{Sr} /{ }^{86} \mathrm{Sr}\right)_{\mathrm{i}}$ ratios and low $\varepsilon \mathrm{Nd}_{(\mathrm{t})}$ values $(+0.20$ to +3.32 : see Fig. 8) and enrichment in LREEs (see Fig. 7e-h), indicating that their precursor magma was derived from a relatively enriched mantle source, possibly related to low degree partial melting, and to the influence of slabderived fluid/ melting released during the subduction process (cf., Faure and Mensing, 2005). Besides, enrichment in LREEs of the volcanic rocks is probably due to metasomatism of mantle sources by fluids or melts from a subdcuted slab. This interpretation can be additionally supported by the elevated LILEs (e.g., Rb, Sr and Ba) relative neighbouring LREEs ( $\mathrm{La}$ and $\mathrm{Ce}$ ) and HFSEs ( $\mathrm{Nb}$ and $\mathrm{Ta}$ ) (Fig. 7e-h), indicating that the enrichment process was closely related to the influx of fluids (e.g., Tatsumi and Takahashi, 2006). Although the the volcanic rocks underwent variable degrees of crystal fractionation, the ratios of trace elements with similar partition coefficients and radiogenic isotope compositions can be used to trace the nature of the mantle source, for they are insensitive to magmatic differentiation. The basic rock samples $\left(\mathrm{SiO}_{2}<50 \mathrm{wt} \%\right)$ have high $\mathrm{Rb} / \mathrm{Y}$ and $\mathrm{Th} / \mathrm{Zr}$, but low $\mathrm{Nb} / \mathrm{Zr}$ and $\mathrm{Nb} / \mathrm{Y}$ ratios (Fig. 9a, b), suggesting that they stemmed from the lithospheric mantle source that has been previously been enriched by slab-derived fluid, rather than hydrous melt (e.g., Kepezhinskas et al., 1996). $\mathrm{Th} / \mathrm{Nb}$ ratios of the samples show a narrow range despite large variations in $\mathrm{Ba} / \mathrm{Nb}$ ratios, thus implying fluid related metasomatism (Fig. 9c). The narrow range in Ce/Yb ratios with increasing Sr/Yb (Fig. 9d) reveals an origin of a metasomatised source modified by fluids generated by dehydrating subducted oceanic crust on the subcontinental mantle lithosphere (Hofmann et al., 1986). On the other hand, the studied rocks have variable $\left({ }^{87} \mathrm{Sr} /{ }^{86} \mathrm{Sr}\right)_{\mathrm{i}}$ ratios and positive $\varepsilon \mathrm{Nd}_{(\mathrm{i})}$ values, which reveal that their mantle source must have been depleted. The decoupling of the isotope and trace element characteristics signifies that the mantle source was indeed metasomatised (and thus enriched in incompatible elements) just briefly before the generation of the Eocene magmatism.

The effect of source mineralogy can be inferred by plotting abundance ratios involving incompatible elements against the concentration of a highly incompatible element. A constant abundance ratio over a wide range of incompatible element concentrations indicates the source ratio (Hofmann et al., 1986), whereas a systematic increase or decrease in abundance ratio reflects the effect of the melting process, specifically the residual minerals that control the bulk-solid/melt partition coefficients (Yang et al., 2003). The element Tb is more incompatible than $\mathrm{Yb}$ in garnet (van Westrenen et al., 2000). Fig. 10a shows the $\mathrm{Tb}_{\mathrm{N}} / \mathrm{Yb}_{\mathrm{N}} \mathrm{vs}$. Th (ppm) variations in the studied rocks $\left(\mathrm{SiO}_{2}<50 \mathrm{wt} \%\right)$ with the horizontal line separating fields expected for melting garnet-bearing lherzolite (high $\mathrm{Tb}_{\mathrm{N}} / \mathrm{Yb}_{\mathrm{N}}$ ) and spinel-bearing lherzolite (low $\mathrm{Tb}_{\mathrm{N}} / \mathrm{Yb}_{\mathrm{N}}$ ) (e.g., Wang et al., 2002). The low to moderate $\mathrm{Tb}_{\mathrm{N}} / \mathrm{Yb}_{\mathrm{N}}$ observed in the studied rocks $\left(\mathrm{SiO}_{2}<50 \mathrm{wt} \%\right)$ suggests that their magma formed in 
the presence of residual spinel and rare garnet. Furthermore, a plot of $\mathrm{Sm}_{N} / \mathrm{Yb}_{\mathrm{N}} \mathrm{vs}$. La $\mathrm{N}_{\mathrm{N}} / \mathrm{Yb}_{\mathrm{N}}$ (Fig. 10b) can be used to distinguish between melting of spinel and garnet lherzolite. Due to the compatibility of $\mathrm{Yb}$ in garnet and the incompatibility of $\mathrm{La}$ and $\mathrm{Sm}, \mathrm{La} / \mathrm{Yb}$ and $\mathrm{Sm} / \mathrm{Yb}$ will be strongly fractionated when melting occurs in the garnet lherzolite field. In contrast, during melting in the spinel stability field, $\mathrm{La} / \mathrm{Yb}$ is only slightly fractionated and $\mathrm{Sm} / \mathrm{Yb}$ is nearly unfractionated. Fig. $10 \mathrm{~b}$ shows wide variations in both $\mathrm{La} / \mathrm{Yb}$ and $\mathrm{Sm} / \mathrm{Yb}$ in the studied rocks $\left(\mathrm{SiO}_{2}<50 \mathrm{wt} \%\right)$, pointing to the major role of spinel relative to garnet during partial melting processes. As shown on Figs. 10c and 10d, the results of REE modelling are first examined in terms of the concentrations of the highly incompatible element $\mathrm{La}$ and less incompatible element Sm. Neither La nor Sm is affected significantly by variations in the source mineralogy (e.g., garnet or spinel) and thus can provide information on the bulk chemical composition of the source. Fig. 10c shows that most of the basic rocks $\left(\mathrm{SiO}_{2}<50 \mathrm{wt} \%\right)$ in the Bafra (Samsun) area have La abundances and $\mathrm{La} / \mathrm{Sm}$ ratios greater than those generated by melting of either a depleted mantle (DM; McKenzie and O'Nions, 1991) or a primitive mantle (PM; Sun and McDonough, 1989) composition. Therefore, the E-MORB mantle composition of McDonough and Sun (1995) was taken as a starting material that melted from 5-10\% under spinel as well as under the garnet lherzolite field conditions. The partial melting trajectories (Fig. 10c) that coincide with the basic rocks $\left(\mathrm{SiO}_{2}<50 \mathrm{wt} \%\right)$ in the Bafra (Samsun) area imply $5-10 \%$ partial melting of the mantle source characterised by La abundances and La/Sm ratios enriched relative to the primitive mantle or depleted mantle. As shown in the La/Yb vs. Yb diagram (Fig. 10d), which considers an EM (enriched mantle) source in the same non-modal batch melting model above, the generation of the basic rocks $\left(\mathrm{SiO}_{2}<50 \mathrm{wt} \%\right)$ cannot be explained by variable degrees of partial melting of an exclusively spinel-bearing or a garnet-bearing lherzolite source. The samples lie on a near-linear mixing line between theoretical spinel and garnet-bearing source melts, so that the simplest melt model involves an initial major partial melting in the spinel stability field followed by mixing of these melts with small melt fractions of garnet lherzolite (Fig. 10d). The values of the basic rocks $\left(\mathrm{SiO}_{2}<50 \mathrm{wt} \%\right)$ in this model can be successfully reproduced by mixing between a $\sim 0.1 \%$ melt of spinel lherzolite and a $\sim 0.5 \%$ melt of garnet lherzolite, which is geochemically reasonable to account for the origin of the basic rocks. Furthermore, the theoretical mixing proportions lie between $40-85 \%$ melt of a spinel lherzolite and $15-60 \%$ melt of a garnet lherzolite.

The results of these calculations suggest that the melts for the basic rocks $\left(\mathrm{SiO}_{2}<50 \mathrm{wt} \%\right)$ of the Bafra (Samsun) area may have been produced by variable amounts of melting in garnet and spinel lherzolite (Figs. 10c and 10d). The variable proportion of melts generated and incorporated at different mantle depths is most probably the consequence of melt processes related to an upwelling asthenospheric mantle. Therefore, it is 
proposed that the different trace element characteristics of the source regions and the decoupling observed between their enrichment (e.g., in LREE) and radiogenic Nd isotope composition (i.e. long-term depletion in $\mathrm{Nd}$ relative to $\mathrm{Sm}$ of the source reservoir) stem from metasomatism of the depleted source (DMM-like) shortly before magma generation. The calculated models (Fig. 10c and d) suggest that the enriched component, although derived from the same mantle region, could have been generated for each group (tephritic and other basaltic rocks) at different depths (i.e. in the garnet-spinel facies) and added in small and essentially similar proportions to the source regions. Subsequently, the metazomatised source region provided melts due to variable degrees of partial melting at shallow-slight deep levels (spinel-garnet lherzolite facies).

\subsection{Role of fractional crystallisation}

Major, trace and rare earth element chemistry of the studied volcanic rocks reveals the importance of crystal fractionation from the parental magma(s). Besides, most of the samples do not represent primary magma compositions and the magmas have undergone significant fractionational crystallisation within crustal magma chamber(s). The variations of major and trace element (see Fig. 6) indicate well-defined positive and/or negative correlations, reflecting the significant effect of fractional crystallisation processes of different mineral phases during the evolution of the studied volcanic rocks, but some scatter (see Fig. 6) may represent variable extents of phenocryst accumulation, or, alternatively, different degrees of partial melting. Decreasing $\mathrm{CaO}$ with increasing $\mathrm{SiO}_{2}$ in Fig. 6 suggests the fractionation of phases such as plagioclase, clinopyroxene, and hornblende. $\mathrm{Sr}$ is a compatible element in plagioclase not clinopyroxene (Wilson, 2007), so a $\mathrm{Sr}$ vs. $\mathrm{MgO}$ plot is used to demonstrate the role of these minerals for decreasing $\mathrm{CaO}$. In the volcanic rocks, Sr increases with increasing $\mathrm{MgO}$ up to $3.06 \mathrm{wt} \%$ (equivalent to $\mathrm{SiO}_{2}=47.4 \mathrm{wt} \%$; except for sample B25) and then decreases (Fig. 11a). Based on petrographic studies, hornblende is absent in the volcanic rocks with $\mathrm{MgO}>3.06$. Moreover, the lack of negative correlations between $\mathrm{Y}$ or $\mathrm{Sm}$, elements with relative high $K_{\mathrm{D}}$ for hornblende-liquid compared to clinopyroxene-liguid, and $\mathrm{Rb}$ (index of fractionation) suggests that hornblende fractionation was not significant (not shown). Therefore, it seems that clinopyroxene was the main fractionated mineral in the volcanic rocks with $\mathrm{MgO}>3.06 \mathrm{wt} \%$, the evolution of magma could be controlled by fractionation of clinopyroxene, plagioclase, and hornblende together. In log-log diagrams of Ba vs Sr (Fig. 11b), it appears that Sr concentration increases from about $425 \mathrm{ppm}$ to $1299 \mathrm{ppm}$ (except for sample B25) with increasing Ba, and then decreases. This is explained only by fractionation of clinopyroxene in the early stage in the volcanic rocks with $\mathrm{SiO}_{2}<47.4 \mathrm{wt} \%$ and by separation of the plagioclase, clinopyroxene, and hornblende together in later stage. $\mathrm{Y}$ and $\mathrm{Yb}$ are 
commonly incompatible elements except when garnet or hornblende is present. Furthermore, a significant decrease in the $\mathrm{Dy} / \mathrm{Yb}$ ratio with silica content can only be attributed to hornblende fractionation (Davidson et al., 2007). In the volcanic rocks, although clinopyroxene fractionation has a limited effect on $\mathrm{Y}$ and $\mathrm{Yb}$ concentrations and $\mathrm{Dy} / \mathrm{Yb}$, a significant decrease in $\mathrm{Y}$ and $\mathrm{Yb}$ occurs in the rocks with $\mathrm{SiO}_{2}>45.6$ wt\% due to hornblende fractionation (Fig. 11c). The studied volcanic rocks display a combined vector of clinopyroxene, hornblende and plagioclase fractionations in Fig. 11d, suggesting that both of these minerals have played significant roles during the magmatic differentiation. Fig. 11d also shows that clinopyroxene and hornblende fractionation was more important than plagioclase in controlling Rb concentration. In Fig. 6, decreasing $\mathrm{P}_{2} \mathrm{O}_{5}$, $\mathrm{TiO}_{2}$, and $\mathrm{Sr}$ with accelerating $\mathrm{SiO}_{2}$ are probably related to apatite, $\mathrm{Fe}-\mathrm{Ti}$ oxide, and plagioclase fractionation, respectively. All these variations can be explained by fractionation of common mineral phases as clinopyroxene \pm plagioclase \pm biotite \pm Fe-Ti oxide in anlacime-bearing volcanic rocks; clinopyroxene + olivine \pm plagioclase \pm hornblende $\pm \mathrm{Fe}$-Ti oxide in basaltic lava flows and basaltic dykes, and plagioclase + biotite \pm sanidine \pm apatite \pm Fe-Ti oxide in trachytic lava flows from analcime-free volcanic rocks (Figs. 6 and 11).

Sr-Nd isotope and several element (or element ratio) correlation plots (see Fig. 11e-h) are also used to evaluate the role of FC and assimilation coupled with fractional crystallisation (AFC) processes for the studied volcanic rocks. All trends in Fig. 11e-h are nearly horizontal, implying that the volcanic rocks mainly evolved by FC controlling the observed compositional differences. Moreover, Fig. 11e-h may also suggest a minor role of the assimilation process for the studied volcanic rocks.

\subsection{Role of crustal assimilation}

The majority of the studied rock samples are porphyritic, suggesting that they might have resided in crustal magma chambers prior to eruption and would thus have had adequate opportunity to interact with continental crust via assimilation-fractional crystallisation (AFC) processes. The fact that the parental magmas of the studied volcanic rocks passed through the continental crust raises the possibility that crustal contamination and/or source mixing produced some of the incompatible trace element signatures. LILEs such as $\mathrm{Rb}, \mathrm{Ba}$, and $\mathrm{K}$ and the HFSEs such as $\mathrm{Zr}$ and $\mathrm{Nb}$ are incompatible with respect to the phenocryst phases in the studied volcanic rocks. Mafic magmas that undergo crustal contamination are also expected to display $\mathrm{Nb}$, $\mathrm{Ti}$ and $\mathrm{P}$ depletion combined with enrichment in Th and LREEs (e.g., Taylor and McLennan, 1995). Ti negative anomalies (compared to the neighbouring Eu and Y) are typical for continental crust on the primitive mantle-normalised multi-element diagrams (Rudnick and Gao, 2003). The studied volcanic rocks show Ti troughs on their multi 
trace-element patterns (see Fig. 7a-d), and thus the continental crustal contribution to the magmas cannot be excluded.

To test the crustal contamination possibility, we perform trace element-(AFC) modelling using the mantle- and upper crustal end-members (Fig. 12a-d). The trace element AFC (DePaolo, 1981) curves (Fig. 12ad) were calculated using a basaltic composition (the Koçevyanı Basalt from the İkizce (Ordu) area; Temizel and Arslan, 2008) as a hypothetical parental magma (IC $\left.C_{0}\right)$, upper continental crust (UCC) as an assimilant ( $\mathrm{Sr}-\mathrm{Nd}$ isotope and trace element values from Davies et al., 1985 and Taylor and McLennan, 1985, respectively), assuming $\mathrm{r}$ (the ratio ofmass assimilation /mass crystallisation) $=0.2,0.4,0.6$ and 0.8 , and using fractionating mineral phases observed in the volcanics. Trace element AFC modelling (DePaolo, 1981) shows that the assimilation/ fractional crystallisation ratio $(r)$ is $\leq 0.2$, suggesting that upper crustal contamination processes play an insignificant role in the evolution of the studied volcanic rocks (Fig. 12a-d). Additionally, to test mantlecrust end member mixing possibilities, we performed Sr-Nd isotopic modelling (e.g., DePaolo and Wasserburg, 1979) using the mantle and lower crust end-members. The isotope modelling scheme is shown in Fig. 12e, where Sr-Nd bulk mixing lines between upper mantle (UM) and middle/lower continental crust (MCC/LCC) compositions are plotted as well as AFC (DePaolo, 1981) curves $(r=0.1-0.4)$ between the hypothetical parental magma $\left(I_{0}\right)$ and upper continental crust (UCC) as an assimilant (Table 6). In the Sr-Nd isotopic end-member mixing modelling, various mixing ratios $(f)$ are also shown from a depleted mantle source towards the middle/lower continental crustal end-members (Fig. 12e). In the Sr-Nd isotopic AFC modelling, bulk distribution coefficients $\left(\mathrm{D}_{\mathrm{Sr}}, \mathrm{D}_{\mathrm{Nd}}\right.$ ), assuming $\mathrm{r}$ (the ratio of mass assimilation to mass $\left.\mathrm{FC}\right)=0.1,0.2,0.25,0.3$ and 0.4 as the AFC numerical index and F (degree of crystallisation) $=0.5 \%$ to a maximum of $0.90 \%$ observed in the studied volcanic rocks as fractionating phases for all AFC curves (Fig. 12e). The Sr-Nd isotopic endmember mixing modelling suggests that the middle/lower crust mixing ratios are between $25-35 \%$, revealing that the parental magma(s) $\left(I \mathrm{C}_{0}\right)$ of the volcanic rocks has been affected by middle/lower continental crust (Fig. 12e). Besides, all volcanic rock samples in the Sr-Nd isotopic AFC modelling plot a lower AFC numerical value of $r=0.2$ than the critical value ( $r=0.25$; Albarède, 1996), suggesting minor upper crustal contamination for the volcanic rocks in the Bafra (Samsun) area (Fig. 12e).

\subsection{Petrogenetic consideration and evolution of high-K to shoshonitic Eocene magmatism}

Since the decoupling of the isotope and trace element characteristics shows that their precursor magma was derived from a lithospheric mantle source that had been previously enriched by earlier (i.e., pre-Eocene) 
subduction processes troughout the Pontides, the Eocene-aged volcanic rocks have a complex evolutionary history including subduction-induced and magma chamber processes, as well as the interaction of melts derived from mantle and crustal components. Also, the plot of highly incompatible element ratios (Fig. 7) shows strong overlap in these ratios for the studied analcime-bearing and -free volcanic rocks, indicating that they were probably derived from similar mantle sources. However, the diversity in the most mafic samples of these two volcanic rock groups reflects compositional differences or the degree of enrichment of incompatible elements in the source regions. The HFSE pairs (e.g. Nb-Ta and $\mathrm{Zr}-\mathrm{Hf}$ ) are generally thought to exhibit concordant geochemical behaviour during mantle melting. Similar to other post-collisional Palaeogene-Neogene volcanic rocks in the Central-Eastern Pontides (Arslan et al., 1997, 2013; Aydınçakır and Şen, 2013; Kaygusuz et al., 2011; Keskin et al., 2008; Temizel and Arslan, 2008, 2009; Temizel et al., 2012; Yücel et al., 2014a), the $\mathrm{Nb}_{\mathrm{N}} / \mathrm{Ta}_{\mathrm{N}}$ ratios of the volcanic rock samples are mostly $<1.3$, whereas the $(\mathrm{Zr} / \mathrm{Hf})_{\mathrm{N}}$ values are close to 1.0 , indicating their enriched mantle source. The strong $\mathrm{Nb}$ - $\mathrm{Ta}$ fractionation ( $\operatorname{most} \mathrm{Nb}_{\mathrm{N}} / \mathrm{Ta}_{\mathrm{N}}<1.3$ ) might be caused by mantle alteration as a result of subduction fluid. This is indicated also by the enrichments of LILEs and depletions of $\mathrm{Nb}$ and $\mathrm{Ti}$ in the primitive mantle normalised plots for the studied volcanic rocks (see Fig. 7a-d). Furthermore, the low $\mathrm{La} / \mathrm{Yb}$ ratios $(<12.4)$ and $\mathrm{Nb} / \mathrm{Y}$ ratios $(<0.30)$ for the volcanic rocks indicate that the metasomatic enrichment of the source regions was caused by a fluid derived from slab dehydration (e.g., Hoffer et al., 2008). This metasomatism explains the high concentrations of $\mathrm{Rb}, \mathrm{Ba}, \mathrm{Sr}, \mathrm{Th}, \mathrm{U}, \mathrm{K}, \mathrm{La}$, and $\mathrm{Ce}$ in the subsequent melts. All volcanic rocks exhibit a variety of disequilibrium textures, such as poikilitic textures in feldspar phenocrysts, sieve textured-patchy-rounded and corroded plagioclases, bladed biotites, acicular apatites, partial melting and dissolution in clinopyroxenes, and resorption features of the ferromagnesian minerals (e.g., Hibbard 1995), similar to those of monzogabbroic stocks (Temizel, 2014) that are volumetrically small intrusives near/close to the studied volcanic rocks. The calculation of mixing models (see Fig. 12e), along with disequilibrium mineral textures, clearly indicates an end-member mixing origin for the studied volcanic rocks. According to such modelling of mixing (see Fig. 12e), the studied volcanic rocks have probably evolved as products of mixing between subduction modified lithospheric mantle and crustal components.

It is well known that the geodynamic evolution of the Palaeogene-Neogene volcanic rocks across or along the Pontides is potentially complicated because of collisional/post-collisional events followed by the subduction and closure of the Neotheytan Ocean in Late Cretaceous times. This complexity led to the development of conflicting geodynamic models for magma genesis in the Palaeogene period. The Middle Eocene magmatism in the Western to Central Pontides has been generally postulated to be extension-related, as 
a result of the opening of the Black Sea basin (e.g., Görür and Tüysüz, 1997; Robinson et al., 1995) or postcollisional slab breakoff beneath the IAES (e.g., Altunkaynak, 2007; Keskin et al., 2008). Furthermore, the widespread Middle Eocene magmatism in the Eastern Pontides (see Fig. 1b) was interpreted as (a) related to the northward subduction of Neotheytan Ocean, the proposed collision occurring during the Oligocene Epoch $(\sim 30$ Ma) (e.g., Robinson et al., 1995), (b) slab window-related processes during ridge subduction in a south-dipping subduction zone (e.g., Eyüboğlu et al., 2011) or (c) post-collisional crustal thickening (Arslan et al., 2001) and delamination of the thickened crust along the IAES (e.g., Arslan et al., 2013; Temizel et al., 2012).

Although the slab breakoff model was suggested as viable model to explain the narrow Middle Eocene volcanism along IAES (e.g., the volcanic units of Hamamözü formation in the Central Pontides; Keskin et al., 2008), the feasibility of the lithospheric delamination model is also accepted to explain the widespread Middle Eocene volcanism at the north of the IAES in the Eastern Pontides (e.g., Arslan et al., 2013; Aslan et al., 2014; Temizel et al., 2012). Besides, the Eastern Pontides are also affected by post-collisional extensional collapse by delamination (Arslan et al., 2013; Aslan et al., 2014; Karslı et al., 2010; Temizel et al., 2012). The extensional collapse and ongoing extension resulted in widespread Middle Eocene and rare Miocene volcanism in the Eastern Pontides (Arslan et al., 2013; Aslan et al., 2014; Temizel et al., 2012; Yücel et al., 2014a).

The studied analcime-bearing and -free volcanic rocks of the Bafra (Samsun) area, as with other Middle Eocene volcanic rocks across the Eastern Pontides, were derived from lithospheric mantle previously metasomatised by subduction-induced fluids in a collisional and post-collisional extension-related geodynamic setting (Arslan and Aliyazıoğlu, 2001; Arslan et al., 2013; Aslan et al., 2014; Aydın et al., 2008; Kaygusuz et al., 2011; Temizel et al., 2012; Yücel et al., 2014a). Likewise, the parental magma generation mechanism for the studied volcanic rocks can also be described by delamination of the thickened continental crust of the Eastern Pontides during Eocene times, possibly within an extention-induced setting after collision $(\sim 55 \mathrm{Ma})$ of the Tauride-Anatolide Platform (TAP) and the Eurasian Plate (EP). Based on the aforementioned points, we propose an evolutionary model for the parental magma(s) generation and differentiation processes in magma chambers of lower to upper crustal levels for the Eocene magmatism as shown in Fig. 13. First of all, basic parental melts were derived from metasomatised subcontinental lithospheric mantle (SCLM) that was modified by subductioninduced fluids/melts (a), and stored in the lower level magma chamber (b). The differentiated basic magma rises to the middle level magma chamber (c), and evolved with $\mathrm{FC} \pm \mathrm{AFC} \pm$ magma mixing processes. The evolved magmas then differentiate further in upper level magma chambers (d), and then rise to the surface. On the other hand, the mantle-derived basic melt storage heats the surrounding crustal materials and causes melting in the 
lower levels (e). Continuation of heat transfer to the crust propagates the crustal melts (f). Ascent of the crustal melts forms the silicic magma chamber at a lower-middle level in the crust $(\mathrm{g})$. The silicic magma chamber generates a trap for rising evolved basic magma, and then basic magma influx to the silicic magma chamber (h). Injection of the basic magma into the silicic magma chamber causes convection, which leads to mixing/mingling between basic and silicic melts while the basic magma chamber fractionates. Large temperature differences between basaltic and silicic magma cause mingling/mixing to occur; the intrusive equivalent (monzogabbroic stocks) reflects a hybrid product formed due to the mingling and partial (incomplete) mixing of these two magmas (e.g., Temizel, 2014; Temizel et al., 2014). The favoured petrogenetic evolutionary model implies that the Middle Eocene volcanic rocks from the Bafra (Samsun) area have evolved by lower to upper-level crustal differentiated processes of parental magma(s) derived from SCLM and lower crustal sources (Fig. 13).

\section{Conclusions}

Mineral chemistry, ${ }^{40} \mathrm{Ar}^{39} \mathrm{Ar}$ dating, whole-rock and Sr-Nd geochemical data of the Bafra (Samsun) area volcanic rocks in the western edge of Eastern Pontides (N Turkey) cast new light on the generation of postcollisional Eocene volcanism. The following points summarise the main concluding remarks based on this study.

The studied volcanic rocks are composed mainly of tephritic and basaltic-trachytic lava flows and rare dykes, showing a fine-grained porphyritic, hyalo-microlitic porphyritic and rare intersertal, trachytic, fluidal and glomeroporphyric textures.

${ }^{40} \mathrm{Ar}-{ }^{39} \mathrm{Ar}$ plateau ages range from $51.38 \pm 0.21 \mathrm{Ma}$ to $44.13 \pm 0.28 \mathrm{Ma}$ for the studied volcanic rock samples. These volcanic rocks are almost coeval with ${ }^{40} \mathrm{Ar}-{ }^{39} \mathrm{Ar}$ ages that vary from $45.04 \pm 0.25 \mathrm{Ma}$ to $44.59 \pm$ 0.19 Ma from monzogabbroic stocks, which are volumetrically small intrusive equivalents.

Petrochemical variations can be explained by fractionation of common mineral phases as clinopyroxene \pm plagioclase \pm biotite \pm Fe-Ti oxide in anlacime-bearing volcanic rocks; clinopyroxene + olivine \pm plagioclase \pm hornblende \pm Fe-Ti oxide in basaltic lava flows and basaltic dykes, and plagioclase + biotite \pm sanidine \pm apatite $\pm \mathrm{Fe}-\mathrm{Ti}$ oxide in trachytic lava flows from analcime-free volcanic rocks. In addition, the volcanic rocks indicate magma evolution from calc-alkaline high-K to shoshonitic compositions.

Depletion in $\mathrm{Nb}$ and Ta relative to LILE, moderate LREE / HREE and high Th/Yb ratios, and Sr-Nd isotope data suggest that dominant fractional crystallisation, lesser magma mixing \pm asimilation played a significant role in the evolution of the volcanic rocks. Moreover, primitive mantle-normalised trace element and chondrite-normalised REE patterns of the analcime-bearing volcanic rocks largely overlap those of the other 
analcime-free volcanic rocks (see Fig. 7), as do their major element data, implying the petrogenetic link between the analcime-bearing and -free volcanic rocks.

The $\mathrm{Sr}$ and $\mathrm{Nd}$ isotopic composition for the volcanic rocks shows a relatively low to moderate initial ${ }^{87} \mathrm{Sr} /{ }^{86} \mathrm{Sr}$ ratio, ranging from $0.7042-0.7051$ and high positive $\varepsilon \mathrm{Nd}_{(\mathrm{t})}$ values $(+0.20$ to +3.32$)$, suggesting lithospheric mantle-derived end-members in their petrogenesis with restricted variations, indicating fairly small crustal contamination. Besides, the ages of the single-stage depleted mantle Nd model $\left(T_{\mathrm{DM} 1}=0.63-0.93 \mathrm{Ga}\right)$, suggest that the lithospheric mantle source for the studied volcanic rocks is Proterozoic in age.

Sr-Nd isotopes combined with major and trace element systematics, and trace element mantle melt modeling, indicates that the parental melts were generated by about 5-10\% partial melting of an enriched lithospheric mantle that is composed mainly of spinel lherzolite with minor involvement of garnet lherzolite. SrNd isotopic mixing modelling suggests $25-35 \%$ lower crustal end-member contribution. Trace element and Sr$\mathrm{Nd}$ isotope AFC modelling indicate insignificant upper crustal contamination during the evolution of the analcime-bearing and -free volcanic rocks.

\section{Acknowledgements}

This study is partly supported by the Scientific Research Projects (no: 1079) of Karadeniz Technical University (Trabzon, Turkey). We thank editor in Chief Nelson Eby, and reviwer Dejan Prelević and anonymous reviewer for their critical and constructive comments to improve our paper. 


\section{References}

Albarède, F., 1996. Introduction to Geochemical Modelling. Cambridge University Press, 543 pp.

Altherr, R., Topuz, G., Siebel, W., Şen, C., Meyer, H.P., Satır, M., Lahaye, Y., 2008. Geochemical and Sr-Nd-Pb isotopic characteristics of Paleocene plagioleucitites from the eastern Pontides (NE Turkey). Lithos 105, 149-161.

Altunkaynak, Ş., 2007. Collision-driven slab breakoff magmatism in northwestern Anatolia, Turkey. Journal of Geology 115, 63-82.

Arslan, M., Aliyazıcıoğlu, İ., 2001. Geochemical and petrological characteristics of the Kale (Gümüşhane) volcanic rocks: implications for the Eocene evolution of eastern Pontide arc volcanism, northeast Turkey. International Geology Review 43, 595-610.

Arslan, M., Aslan, Z. 2006. Mineralogy, petrography and whole-rock geochemistry of the Tertiary granitic intrusions in the Eastern Pontides, Turkey. Journal of Asian Earth Sciences 27, 177-193.

Arslan, M., Hoskin, P.W.O., Aslan, Z. 2001. Continental crust formation and thermal consequences of Cenozoic thickening of the Eastern Pontides Tectonic unit: Preliminary temporal constraints and implications. Fourth International Turkish Geology Symposium, Adana-Turkey, Abstracts, p. 121.

Arslan, M., Temizel, İ., Abdioğlu, E., Kolaylı, H., Yücel, C., Boztuğ, D., Şen, C., 2013. ${ }^{40} \mathrm{Ar}-{ }^{39} \mathrm{Ar}$ dating, whole-rock and Sr$\mathrm{Nd}-\mathrm{Pb}$ isotope geochemistry of post-collisional Eocene volcanics in the southern part of the Eastern Pontides (NE Turkey): Implications for magma evolution in extension-induced origin. Contributions to Mineralogy and Petrology $166,113-142$.

Arslan, M., Tüysüz, N., Korkmaz, S., Kurt, H., 1997. Geochemistry and petrogenesis of the eastern Pontide volcanic rocks, Northeast Turkey. Chemie Der-Erde Geochemistry 57, 157-187.

Aslan, Z., Arslan, M., Temizel, I., Kaygusuz, A., 2014. K-Ar age, whole-rock and Sr-Nd isotope geochemistry of calcalkaline volcanics around the Gümüşhane area (NE Turkey): implications for post-collisional volcanism during Tertiary time in the eastern Pontides. Mineralogy and Petrology 108, 245-267.

Aydin F, Karslı O, Chen B (2008) Petrogenesis of the Neogene alkaline volcanics with implications for post-collisional lithospheric thinning of the Eastern Pontides, NE Turkey. Lithos 104:249-266

Aydınçakır, E., Şen, C., 2013. Petrogenesis of the post-collisional volcanic rocks from the Borçka (Artvin) area: implications for the evolution of the Eocene magmatism in the Eastern Pontides (NE Turkey). Lithos 172-173, 98-117.

Bacon, C.R., Hirschmann, M.M., 1988. Mg/Mn partitioning as a test for equilibrium between coexiting Fe-Ti oxides. American Mineralogist 73, 57-61.

Ben Othman, D., Polve, M., Allegre, C.J., 1984. Nd-Sr isotopic composition of granulites and constraints on the evolution of the lower continental crust. Nature 307, 510-515.

Conticelli, S., Peccerillo, A., 1992. Petrology and geochemistry of potassic and ultrapotassic volcanism in central Italy: petrogenesis and inferences on the evolution of themantle sources. Lithos 28, 221-240. 
Conticelli, S., Guarnieri, L., Farinelli, A., Mattei, M., Avanzinelli, R., Bianchini, G., Boari, E., Tommasini, S., Tiepolo, M., Prelević, D., Venturelli, G., 2009. Trace elements and Sr-Nd-Pb isotopes of K-rich, shoshonitic, and calc-alkaline magmatism of theWestern Mediterranean Region: genesis of ultrapotassic to calc-alkaline magmatic associations in a post-collisional geodynamic setting. Lithos 107, 68-92.

Davidson, J., Turner, S., Handley, H., Macpherson, C., Dosseto, A., 2007. Amphibole 'sponge' in arc crust? Geology 35 , 787-90.

Davies, G., Gledhilla, A., Hawkesworth, C., 1985. Upper crustal recycling in southern Britain: evidence from Nd and $\mathrm{Sr}$ isotopes. Earth and Planetary Science Letters 75, 1, 1-12.

Davies, J.H., von Blanckenburg, F., 1995. Slab breakoff: a model of lithospheric detachment and its test in the magmatism and deformation of collisional orogens. Earth and Planetary Science Letters 129, 85-102.

Deer, W.A., Howie, R.A., Zussman, J., 1992. An Introduction to the Rock Forming Minerals, 2nd ed., Longman, London, 696 pp.

DePaolo, D.J., Wasserburg, G.J., 1979. Petrogenetic mixing models and Nd-Sr isotopic patterns. Geochimica et Cosmochimica Acta 43, 615-627.

DePaolo, D.J., 1981. Trace element and isotopic effects of combined wallrock assimilation and fractional crystallization. Earth and Planetary Science Letters 53:189-202

Dilek, Y., Altunkaynak, Ş., 2010. Geochemistry of Neogene-Quaternary alkaline volcanism in western Anatolia, Turkey, and implications for the Aegean mantle. International Geology Review 52 (4-6), 631-655.

Ersoy, E.Y., Helvacı, C., Uysal, I., Karaoğlu, O., Palmer, M.R., Dindi, F., 2012. "Petrogenesis of the Miocene volcanism along the İzmir-Balıkesir Transfer Zone in western Anatolia, Turkey: implications for origin and evolution of potassic volcanism in postcollisional areas”, Journal of Volcanology and Geothermal Research 241-242, 21-38.

Eyüboğlu, Y., Santosh, M., Chung, S.L., 2011. Crystal fractionation of adakitic magmas in the crust-mantle transition zone: Petrology, geochemistry and U-Pb zircon chronology of the Seme adakites, Eastern Pontides, NE Turkey. Lithos $121,151-166$.

Faure, G., Mensing, T.M., 2005. Isotopes: Principles and Applications, 3rd ed. John Wiley and Sons, USA, 897p.

Foley, S., Peccerillo, A., 1992. Potassic and ultrapotassic magmas and their origin. Lithos 28, 181-185.

Foley, S.F., Venturelli, G., Green, D.H., Toscani, L., 1987. The ultrapotassic rocks: characteristics, classification, and constraints for petrogenetic models. Earth Science Reviews 24, 81-134.

Gaffney, A.M., Blichert-Toft, J., Nelson, B.K., Bizzarro, M., Rosing, M., Albarède, F., 2007. Constraints on source-forming processes of West Greenland kimberlites inferred from Hf-Nd isotope systematics. Geochimica et Cosmochimica Acta 71, 2820-2836.

Gedik, A., Ercan, T., Korkmaz, S., 1984. Orta Karadeniz (Samsun-Sinop) havzasının jeolojisi ve volkanik kayaçlarının petrolojisi, MTA Enst. Dergisi 99-100, 34-50.

Gill, J.B., 1981. Orogenic Andesites and Plate Tectonics. Springer, Berlin. 390p. 
Görür, N., Tüysüz, O., 1997. Petroleum geology of the southern continental margin of the Black Sea, in Robinson AG (Ed.), Regional and Petroleum geology of the Black Sea and surrounding region. American Association of Petroleum Geologists Memoir 68, 241-254.

Guo, Z.F.,Wilson, M., Zhang,M.L., Cheng, Z.H., Zhang, L.H., 2013. Post-collisional, K-richmafic magmatism in south Tibet: constraints on Indian slab-to-wedge transport processes and plateau uplift. Contributions to Mineralogy and Petrology 165, 1311-1340.

Güven, İ.H., 1993. Doğu Pontidler'in 1:25000 ölçekli jeolojisi ve kompilasyonu [1:25000 Scale Geology and Compilation of the Eastern Pontide]. General Directorate of Mineral Research and Exploration of Turkey (MTA), Ankara [unpublished].

Hastie, A.R., Kerr, A.C., Pearce, J.A., Mitchell, S.F., 2007. Classification of altered volcanic island arc rocks using immobile trace elements: development of the Th-Co discrimination diagram. Journal of Petrology 48, 2341-2357.

Hibbard, M.J. 1995. Petrography to Petrogenesis. Prentice Hall, New Jersey.

Hoffer, G., Eissen, J.P., Beate, B., Bourdon, E., Fornari, M., Cotton, J., 2008. Geochemical and petrological constraints on rear-arc magma genesis processes in Ecuador: the Puyo cones and Mera lavas volcanic formations. Journal of Volcanology and Geothermal Research 176(1), 107-118.

Hofmann, A.W., Jochum, K.P., Seufert, M., White, W.M., 1986. Nb and Pb in oceanic basalts: new constraints on mantle evolution. Earth and Planetary Science Letters 79, 33-45.

Irvine, T.N., Baragar, W.R.A., 1971. A guide to the chemical classification of common volcanic rocks. Canadian Journal of Earth Sciences 8, 523-548.

Karsl1, O., Dokuz, A., Uysal, İ., Ketenci, M., Chen, B., Kandemir, R., 2012. Deciphering the shoshonitic monzonites with Itype characteristic, the Sisdağı pluton, NE Turkey: magmatic response to continental lithospheric thinning. Journal of Asian Earth Sciences 51, 45-62.

Karsl1, O., Dokuz, A., Uysal, İ., Aydın, F., Kandemir, R., Wijbrans, R.J., 2010. Generation of the early Cenozoic adakitic volcanism by partial melting of mafic lower crust, Eastern Turkey: implications for crustal thickening to delamination. Lithos 114, 109-120.

Kaygusuz, A., Arslan, M., Siebel, W., Sipahi, F., İlbeyli, N., 2012. Geochronological evidence and tectonic significance of Carboniferous magmatism in the southwest Trabzon area, eastern Pontides, Turkey. International Geology Review 54(15), 1776-1800.

Kaygusuz, A., Aslan, Z., Siebel, W., Şen, C., 2011. Geochemical and Sr-Nd Isotopic Characteristics of Post-Collisional CalcAlkaline Volcanics in the Eastern Pontides (NE Turkey). Turkish Journal of Earth Sciences 20, 137-159.

Kaygusuz, A., Chen, B., Aslan, Z., Siebel, W., Şen, C., 2009. U-Pb Zircon SHRIMP Ages, Geochemical and Sr-Nd Isotopic Compositions of the Early Cretaceous I-Type Sarıosman Pluton, Eastern Pontides, NE Turkey. Turkish Journal of Earth Sciences 18, 549-581. 
Kaygusuz, A., Öztürk, M., 2015. Geochronology, geochemistry, and petrogenesis of the Eocene Bayburt intrusions, Eastern Pontides, NE Turkey: Evidence for lithospheric mantle and lower crustal sources in the high-K calc-alkaline magmatism. Journal of Asian Earth Sciences 108, 97-116.

Kaygusuz, A., Siebel ,W., İlbeyli, N., Arslan, M., Satır, M., Şen, C., 2010. Insight into magma genesis at convergent plate margins -a case study from the eastern Pontides (NE Turkey). Neues Jahrbuch für Mineralogie Abhandlungen 187(3), 265-287.

Kaygusuz, A., Şen, C., Aslan, Z., 2006. Petrographic and petrological features of Torul (Gümüşhane) volcanites (NE Turkey); evidences for fractional crystallisation and magma mixing/mingling. Geological Bulletin of Turkey 49, 4982.

Kepezhinskas, P., Defant, M., Drummond, M., 1996. Progressive enrichment of island arc mantle by melt-peridotite interaction inferred from Kamchatka xenoliths. Geochimica et Cosmochimica Acta 60, 1217-1229.

Keskin, M., Genç, Ş. C., Tüysüz, O., 2008. Petrology and geochemistry of post-collisional Middle Eocene volcanic units in North-Central Turkey: Evidence for magma generation by slab breakoff following the closure of the Northern Neotethys Ocean. Lithos 104, 267-305.

Kinzler, R.J., 1997. Melting ofmantle peridotite at pressure approaching the spinel to garnet transition: application to mid ocean ridge petrogenesis. Journal of Geophysical Research 102, 853-874.

Le Bas, M.J., Le Maitre, R.W., Streckeisen, A., Zanettin, B., 1986. A chemical classification of volcanic rocks on the total alkali-silica diagram. Journal of Petrology 27 (3), pp. 745-750.

Le Maitre, R.W., Bateman, P., Dudek, A. et al., 1989. A Classification of Igneous Rocks and Glossary of Terms, Blackwell, Oxford.

Leake, E.B., Wooley, A.R., Arps, C.E.S., et al., 1997. Nomenclature of amphiboles report of the subcommittee on amphiboles of the International Mineralogical Association Commission on New Minerals and Mineral Names. European Journal of Mineralogy 9, 623-651.

McKenzie, D., O’Nions, R.K., 1991. Partial melt distributions from inversion of rare earth element concentrations. Journal of Petrology 32, 1021-1091.

Morimoto, N., Fabries, J., Ferguson, A.K., Ginzburg, I.V., Ross, M., Seifert, F.A., Zussman, J., Aoki, K., Gottardi, G., 1988. Nomenclature of pyroxenes. Mineralogical Magazine 52, 535-550.

Münker, C., Wörner, G., Yogodzisnki, G., Churikova, T., 2004. Behaviour of high Field strength elements in subduction zones: Constraints from Kamchatka-Aleutian arc lavas. Earth and Planetary Science Letters 224(3-4), 275-293.

Okay, A.İ., Şahintürk, Ö., 1997. Geology of the eastern Pontides, in: Robinson, A.G. (Ed.), Regional and Petroleum Geology of the Black Sea and Surrounding Region. American Association of Petroleum Geologists Memoir 68, 291-311.

Okay, A.İ., Tüysüz, O., 1999. Tethyan sutures of northern Turkey. Geological Society London Special Publications 156, 475515. 
Pearce, J.A., 1983. Role of the sub-continental lithosphere in magma genesis at active continental margins. In: Hawkesworth CJ, Norry MJ (eds.), Continental Basalts and Mantle Xenoliths. Shiva, Natwich, pp. 230-249.

Peccerillo, A., 2005. Plio-Quaternary volcanism in Italy. Petrology, Geochemistry, Geodynamics. Springer, Heidelberg, Newyork, 365pp.

Peccerillo, A., Taylor, S.R., 1976. Geochemistry of Eocene calc-alkaline volcanic-Rocks from Kastamonu area, Northern Turkey. Contributions to Mineralogy and Petrology 58(1), 63-81.

Plank, T., Langmuir, C.H., 1998. The geochemical composition of subducting sediment and its consequences for the crust and mantle. Chemical Geology 145, 325-394.

Prelević, D., Foley, S.F., Romer, R., Conticelli, S., 2008. Mediterranean Tertiary lamproites derived from multiple source components in postcollisional geodynamics. Geochimica et Cosmochimica Acta 72, 2125-2156.

Prelević, D., Stracke, A., Foley, S.F., Romer, R.L., Conticelli, S., 2010. Hf isotope compositions of Mediterranean lamproites: mixing of melts fromasthenosphere and crustally contaminated mantle lithosphere. Lithos 119, 297-312.

Prelević, D., Jacob, Dorrit, E., Foley, S.F., 2013. Recycling plus: a new recipe for the formation of Alpine-Himalayan orogenic mantle lithosphere. Earth and Planetary Science Letters 362, 187-197.

Prelević, D., Akal, C., Romer, R.L. Mertz-Kraus, R., Helvac1, C., 2015. Magmatic Response to Slab Tearing: Constraints from the Afyon Alkaline Volcanic Complex, Western Turkey. Journal of Petrology 56(3), 527-562.

Rehkamper, M., Hofmann, A.W., 1997. Recycled ocean crust and sediment in Indian Ocean MORB. Earth and Planetary Science Letters 147, 93-106.

Robinson, A.G., Banks, C.J., Rutherford, M.M., Hirst, J.P.P., 1995. Stratigraphic and structural development of the eastern Pontides, Turkey. Geological Society of London 152, 861-872.

Rudnick, R.L., Gao, S., 2003. The composition of the continental crust. In: Rudnick, R.L. (Ed.), The Crust. In: Holland, H.D., Turekian, K.K., (Eds.), Treatise on Geochemistry, vol. 3. Elsevier-Pergammon, Oxford. 64 pp.

Rudnick, R.L., Fountain, D.M., 1995. Nature and composition of the continental-crust: a lower crustal perspective. Reviews of Geophysics 33, 3, 267-309.

Ruffet, G., Féraud, G., Ballèvre, M., Kiénast, J. R., 1995. Plateau ages and excess argon in phengites: an 40Ar-39Ar laser probe study of Alpine micas (Sesia Zone, Western Alps, northern Italy). Chemical Geology (Isotopic Geoscience Section) $121,327-343$.

Ruffet, G., Gruau, G., Ballèvre, M., Féraud, G., Philippot, P., 1997. Rb-Sr and ${ }^{40} \mathrm{Ar}-{ }^{39}$ Ar laser probe dating of high-pressure phengites from the Sesia zone (western Alps): underscoring of excess argon and new age constraints on the highpressure metamorphism. Chemical Geology 141, 1-18.

Semiz, B., Ersoy, E.Y., Özpınar, Y., Helvacı, C., Palmer, M.R., Billor, M.Z., 2015. “ ${ }^{40} \mathrm{Ar} /{ }^{39} \mathrm{Ar}$ geochronology, geochemistry and petrology of volcanic rocks from the Simav Graben, western Turkey”, Contribution to Mineralogy and Petrology $170(24)$.

Shaw, D.M., 1970. Trace element Fractionation during Anatexis. Geochimica et Cosmochimica Acta 34, 237-259. 
Steiger, R.H., Jäger, E., 1977. Subcommission on geochronology: convention on the use of decay constants in geo- and cosmochronology. Earth and Planetary Science Letters 36, 359-362.

Sun, S.S., Mcdonough, W.F., 1989. Chemical and isotopic systematics of oceanic basalts: implications for mantle composition and processes, in: Saunders, A.D., Norry, M.J. (Eds.), Magmatism in the Ocean Basins. Geological Society of London, Special Publications 42, 313-345.

Şen, C., 2007. Jurassic volcanism in the Eastern Pontides: is it rift related or subduction related? Turkish Journal of Earth Sciences $16,523-539$.

Şen, C., Arslan, M., Van. A., 1998. Geochemical and petrological characteristics of the Pontide Eocene (?) alkaline province, NE Turkey. Turkish Journal of Earth Sciences 7, 231-239.

Şengör, A.M.C., Yılmaz, Y., 1981. Tethyan evolution of Turkey: a plate tectonic approach. Tectonophysics 75, 181-241.

Tatsumi, Y., Takahashi, T., 2006. Operation of subduction factory and production of andesite. Journal of Mineralogical and Petrological Sciences 101, 145-153.

Taylor, S.R., Mclennan, S.M., 1985. The Continental Crust: Its Composition and Evolution. Blackwell, Scientific Publication, Oxford, 312

Taylor, S.R., Mclennan, S.M., 1995. The geochemical evolution of the continental crust. Reviews of Geophysics 33, 241-65.

Taylor, S.R., McLennan, S.M., 2009. Planetary crusts: their composition, origin and evolution. Cambridge University Press, Cambridge 1-378.

Temizel, İ., 2014. Petrochemical evidence of magma mingling and mixing in the Tertiary monzogabbroic stocks around the Bafra (Samsun) area in Turkey: implications of coeval mafic and felsic magma interactions. Mineralogy and Petrology 108, 353-370.

Temizel, İ., Arslan, M., 2008. Petrology and geochemistry of Tertiary volcanic rocks from the İkizce (Ordu) area, NE Turkey: Implications for the evolution of the eastern Pontide paleo-magmatic arc. Journal of Asian Earth Sciences $31,439-463$.

Temizel, İ., Arslan, M., 2009. Mineral chemistry and petrochemistry of post-collisional Tertiary mafic to felsic cogenetic volcanics in the Ulubey (Ordu) area, eastern Pontides, NE Turkey. Turkish Journal of Earth Sciences 18, 29-53.

Temizel, İ., Arslan, M., Ruffet, G., Peucat, J.J., 2012. Petrochemistry, geochronology and Sr-Nd isotopic systematics of the Tertiary collisional and post-collisional volcanic rocks from the Ulubey (Ordu) area, eastern Pontide, NE Turkey: implications for extension-related origin and mantle source characteristics. Lithos 128, 126-147.

Temizel, İ., Arslan, M., Abdioğlu, E., Yücel, C., 2014. Mineral chemistry and thermobarometry of the Eocene monzogabbroic stocks from the Bafra (Samsun) area in Turkey: implications for disequilibrium crystallization and emplacement condition. International Geology Review 56(10), 1226-1245.

Topuz, G., Altherr, R., Siebel, W., Schwarz, W.H., Zack, T., Hasözbek, A., Barth, M., Satır, M., Şen, C., 2010. Carboniferous high-potassium I-type granitoid magmatism in the Eastern Pontides: The Gümüşhane pluton (NE Turkey). Lithos 116, 92-110. 
Topuz, G., Okay, A.I., Altherr, R., Schwarz, W.H., Siebel, W., Zack, T., Satır, M., Şen, C., 2011. Post-collisional adakite-like magmatism in the Ağvanis Massif and implications for the evolution of the Eocene magmatismin the Eastern Pontides (NE Turkey). Lithos 125(1-2), 131-150.

van Westrenen, W., Blundy, J.D., Wood, B.J., 2000. Effect of $\mathrm{Fe}^{2+}$ on garnet-melt trace element partitioning: experiments in FCMAS and quantification of crystal-chemical controls in natural systems. Lithos 53, 189-201.

Walter, M.J., 1998. Melting of garnet peridotite and the origin of komatiite and depleted lithosphere. Journal of Petrology 39 , 29-60.

Wang, X.X., Wang, T., Happala, I., Lu, X.X., 2002. Genesis of mafic enclaves from rapakivi-textured granites in the Qinling and its petrological significance: evidence of elements and Nd, Sr isotopes. Acta Petrologica Sinica 21, 935-946 (in Chinese with English abstract).

Weis, D., Kieffer, B., Maerschalk, C., Barling, J., de Jong, J., Willians, G.A., Hanano, D., Pretorius, W., Scoates, J.S., Goolaerts, A., Friedman, R.M., Mahoney, J.B., 2006. High-precision isotopic characterization of USGS reference materials by TIMS and MC-ICP-MS. Geochemistry Geophysics Geosystems 7, 1-30.

Wilson, M., 2007. Igneous Petrogenesis. Chapman \& Hall, London.

Xiaoming, Q., Hou, Z., Zaw, K., Youguo, L., 2007. Characteristics and genesis of Gangdese porphyry copper deposits in the southern Tibetan Plateau: preliminary geochemical and geochronological results. Ore Geology Reviews 31, 205-223.

Yang, H.J., Frey, F.A., Clague, D.A., 2003. Constraints on the source components of Lavas forming the Hawaiian North Arch and Honolulu Volcanics. Journal of Petrology 44, 603-627.

Yılmaz, Y., Tüysüz, O., Yiğitbaş, E., Genç, Ş.C., Şengör, A.M.C., 1997. Geology and tectonics of the Pontides. In: Robinson AG (Ed.), Regional and Petroleum Geology of the Black Sea and Surrounding Region. American Association of Petroleum Geologists Memoir 68, 183-226.

Yücel, C., Arslan, M., Temizel, İ., Abdioğlu, E., 2014a. Volcanic facies and mineral chemistry of Tertiary volcanics in the northern part of the Eastern Pontides, northeast Turkey: implications for pre-eruptive crystallization conditions and magma chamber processes. Mineralogy and Petrology 108, 439-467.

Yücel, C., Temizel, İ, Abdioğlu, E., Arslan, M., Yağcioğlu, U.C., 2014b. Origin of analcimes in the Tertiary volcanic rocks from the Eastern Pontides (NE Turkey): a textural, mineralogical and geochemical approach. Journal of Mineralogy and Geochemistry 191(3), 277-299.

Zellmer, G.F., Annen, C., Charlier, B.L.A., George, R.M.M., Turner, S.P., Hawkesworth, C.J., 2005. Magma evolution and ascent at volcanic arcs: constraining petrogenetic processes through rates and chronologies. Journal of Volcanology and Geothermal Research 140, 171-191.

Zindler, A., Hart, S.R., 1986. Chemical geodynamics. Annual Review of Earth and Planetary Sciences 14, 493-571.

Zindler, A., Staudigel, H., Batiza, R., 1984. Isotope and trace element geochemistry young Pacific seamounts: implications for the scale of upper mantle heterogeneity. Earth and Planetary Science Letters 70, 175-195. 


\section{Figures Captions and Figures}

Fig. 1. (a) Tectonic map of north-eastern Mediterranean region showing the major sutures and continental blocks. Sutures are shown by heavy lines with the polarity of former subduction zones indicated by filled triangles. Heavy lines with open triangles represent active subduction zones (modified after Okay and Tüysüz, 1999), (b) simplified geological map of the Eastern Pontides showing the distribution of the Tertiary volcanic rocks and intrusions (modified after Güven, 1993; Arslan et al., 2013; Temizel, 2014). NAFZ: North Anatolian Fault Zone.

Fig. 2. Simplified geological map of the Bafra (Samsun) area showing the distribution of the studied volcanic rocks and intrusive equivalents (modified after Güven, 1993; Temizel, 2014).

Fig. 3. (a) Classification of feldspars on a ternary An-Ab-Or plot (after Deer et al., 1992), (b) clinopyroxene classification diagram (after Morimoto et al., 1988), (c) hornblende classification diagram (after Leake et al., 1997), (d) olivine classification diagram and (e) the ternary $\mathrm{Ti}^{4+}-\mathrm{Fe}^{2+}-\mathrm{Fe}^{3+}$ diagram of $\mathrm{Fe}-\mathrm{Ti}$ oxides (after Bacon and Hirschmann, 1988) of the volcanic rock samples from the Bafra (Samsun) area.

Fig. 4. ${ }^{40} \mathrm{Ar}-{ }^{39} \mathrm{Ar}$ step-heating results are shown as apparent age spectra of volcanic rocks and intrusive equivalents from the Bafra (Samsun) area. The age error bars for each temperature steps are at the $1 \sigma$ level and do not include errors in the J-values. The errors in the J-values $(0.2 \%)$ are included in the plateau age calculations.

Fig. 5. Chemical classification and nomenclature plots of the volcanic rock samples from the Bafra (Samsun) area using (a) the total alkalis vs. silica (TAS) diagram (after Le Bas et al., 1986) (the alkaline and subalkaline discrimination line after Irvine and Baragar, 1971), (b) $\mathrm{SiO}_{2}$ vs. $\mathrm{K}_{2} \mathrm{O}$ diagram (after Peccerillo and Taylor, 1976), (c) Th vs. Co diagram (after Hastie et al., 2007) and (d) $\Delta \mathrm{Q}$ vs. $\mathrm{K}_{2} \mathrm{O} / \mathrm{Na}_{2} \mathrm{O}$ diagram (after Peccerillo, 2005) (q, normative quartz; lc, normative leucite; ne, normative nepheline; kal, normative kalsilite; ol, normative olivine).

Fig. 6. $\mathrm{SiO}_{2}(\mathrm{wt} \%)$ vs. major oxide (wt\%), trace (ppm) and rare earth element (ppm) variation plots of the volcanic rock samples from the Bafra (Samsun) area. Symbols are as in Fig. 5b.

Fig. 7. (a) Primitive mantle (Sun and McDonough, 1989) normalized multi-element spider diagrams and (b) chondrite (Taylor and McLennan, 1985) normalized rare earth element patterns plots of the volcanic rock samples from the Bafra (Samsun) area.

Fig. 8. (a) $\left({ }^{143} \mathrm{Nd} /{ }^{144} \mathrm{Nd}\right)_{\mathrm{i}}$ vs. $\left.\left({ }^{87} \mathrm{Sr} /{ }^{86} \mathrm{Sr}\right)\right)_{\mathrm{i}}$ plot for the volcanic rock samples of the Bafra (Samsun) area, including the Middle Miocene volcanics NE-Turkey (Temizel et al., 2012; Aslan et al., 2014), Middle Eocene intrusives (Karslı et al., 2012; Temizel, 2014) and volcanics (Kaygusuz et al., 2011; Temizel et al., 2012; Arslan et al., 2013, Aslan et al., 2014) from NE-Turkey, ultrapotassic rocks from Macedonia and W-Turkey (Prelević et al., 2008), Early-Middle Miocene high-K calc-alkaline rocks from W-Turkey (Ersoy et al., 2012; Semiz et al., 2015), and ultrapotassic rocks from Spain and Italy (Conticelli and Peccerillo, 1992; Prelević et al., 2008). Data for 
lithospheric mantle array from Davies and von Blanckenburg (1995). Compositions of MORB (Mid Ocean Ridge Basalt) and Mantle Array from Gill (1981); EMI (enriched mantle type I), HIMU (high $\mu v$ : mantle with high U/Th ratio), UM (Depleted Mantle) fields and CHUR (Chondritic Uniform Reservoir)-Sr and -Nd reference lines after Zindler and Hart (1986); GLOSS (Global Subducting Sediment) from Plank and Langmuir (1998). Symbols are as in Fig. 5b.

Fig. 9. (a) Rb/Y vs. Nb/Y, (b) $\mathrm{Nb} / \mathrm{Zr}$ vs. $\mathrm{Th} / \mathrm{Zr}$, (c) $\mathrm{Th} / \mathrm{Nb}$ vs. $\mathrm{Ba} / \mathrm{Nb}$, and (d) $\mathrm{Ce} / \mathrm{Yb}$ vs. Sr/Yb diagrams for the basic samples $\left(\mathrm{SiO}_{2}<50 \mathrm{wt} \%\right)$ of the Bafra (Samsun) volcanic rocks. Trends associated with fluid- and meltrelated enrichment from Kepezhinskas et al. (1996). The samples as a whole, showing varied $\mathrm{Rb} / \mathrm{Y}, \mathrm{Th} / \mathrm{Zr}$, $\mathrm{Ba} / \mathrm{Nb}$ and $\mathrm{Sr} / \mathrm{Yb}$ ratios, indicate the fluid-related enrichment of subducted materials. Symbols are as in Fig. $5 \mathrm{~b}$.

Fig. 10. (a) Th (ppm) vs. $\mathrm{Tb}_{\mathrm{N}} / \mathrm{Yb}_{\mathrm{N}}$ and (b) $\mathrm{La}_{\mathrm{N}} / \mathrm{Yb}_{\mathrm{N}}$ vs. $\mathrm{Sm}_{\mathrm{N}} / \mathrm{Yb}_{\mathrm{N}}$ plots for the basic samples $\left(\mathrm{SiO}_{2}<50\right.$ wt $\left.\%\right)$ of the Bafra (Samsun) area. Horizontal line separates fields expected for melting garnet- and spinel-lherzolite as determined for Basin and Range basalts (Wang et al., 2002); (c) La vs. La/Sm and (d) La/Yb vs. Yb plots showing melt curves (or lines) obtained using the non-modal batch melting equations of Shaw (1970) for the basic samples $\left(\mathrm{SiO}_{2}<50 \mathrm{wt} \%\right)$. (c) Melt curves are drawn for spinel-lherzolite (with mode and melt mode of $\mathrm{ol}_{0.53}$ $+\mathrm{opx}_{0.27}+\mathrm{cpx}_{0.17}+\mathrm{sp}_{0.11}$ and $\mathrm{ol}_{0.06}+\mathrm{opx}_{0.28}+\mathrm{cpx}_{0.67}+\mathrm{sp}_{0.11}$; respectively; Kinzler, 1997) and for garnetlherzolite (with mode and melt mode of $\mathrm{ol}_{0.6}+\mathrm{opx}_{0.2}+\mathrm{cpx}_{0.1}+\mathrm{gt}_{0.1}$ and $\mathrm{ol}_{0.03}+\mathrm{opx}_{0.16}+\mathrm{cpx}_{0.88}+\mathrm{gt}_{0.09}$; respectively; Walter, 1998). Mineral/matrix partition coefficients and depleted mantle (DM) are from the compilation of McKenzie and O'Nions (1991); PM, N- and E-MORB compositions are from Sun and McDonough (1989). The bold line represents the mantle array defined using DM, PM and E-MORB compositions. Dashed and solid curves (or lines) are the melting trends from DM and E-MORB, respectively. Thick marks on each curve (or line) correspond to degrees of partial melting for a given mantle source; (d) Melt curves are drawn for spinel-lherzolite (with mode and melt mode of $\mathrm{ol}_{0.578}+\mathrm{opx}_{0.27}+\mathrm{cpx}_{0.119}+\mathrm{sp}_{0.033}$ and ol ${ }_{0.1}+$ $\mathrm{opx}_{0.27}+\mathrm{cpx}_{0.5}+\mathrm{sp}_{0.13}$; respectively) and for garnet-lherzolite (with mode and melt mode of ol ${ }_{0.598}+\mathrm{opx}_{0.211}+$ $\mathrm{cpx}_{0.076}+\mathrm{gt}_{0.115}$ and $\mathrm{ol}_{0.05}+\mathrm{opx}_{0.20}+\mathrm{cpx}_{0.30}+\mathrm{gt}_{0.45}$; respectively). Mineral/matrix partition coefficients are from the compilation of McKenzie and O'Nions (1991). The source is assumed to be enriched mantle composition evolved from the primitive mantle composition defined by Taylor and McLennan (2009), namely La = $1.2 \times 0.546 \mathrm{ppm}$ and $\mathrm{Yb}=0.9 \times 0.368 \mathrm{ppm}$. Curves are also shown that represent mixing between small melt fractions within the garnet stability field in the mantle and larger melt fractions within the spinel stability field of the mantle. Symbols are as in Fig. 5b.

Fig. 11. (a) $\mathrm{Sr}$ (ppm) vs. $\mathrm{MgO}$ (wt\%), (b) $\mathrm{Ba}(\mathrm{ppm})$ vs. $\mathrm{Sr}$ (ppm), (c) $\mathrm{Dy} / \mathrm{Yb}$ vs. $\mathrm{SiO}_{2}$ (wt\%), (d) $\mathrm{K}_{2} \mathrm{O} / \mathrm{Rb}$ vs. $\mathrm{Rb}$ (ppm), (e) $\left({ }^{87} \mathrm{Sr} /{ }^{86} \mathrm{Sr}\right)_{\mathrm{i}}$ vs. $\mathrm{SiO}_{2}(\mathrm{wt} \%)$ and $(\mathrm{f})\left({ }^{143} \mathrm{Nd} /{ }^{144} \mathrm{Nd}\right)_{\mathrm{i}}$ vs. Sm/Nd plots showing possible fractional crystallization (FC) and/or assimilation-fractional crystallization (AFC) trends for the volcanic rock samples of the Bafra (Samsun) area. Arrows indicate compositional changes due to the fractionation of minerals. Pl, plagioclase; Cpx, clinopyroxene; K-f, K-feldspar; Hbl, hornblende; Bi, biotite. Symbols are as in Fig. 5 b.

Fig. 12. (a) La/Nb vs. $\mathrm{La}(\mathrm{ppm})$, (b) $\mathrm{Nb}$ (ppm) vs. $\mathrm{La}(\mathrm{ppm})$, (c) $\mathrm{Zr} / \mathrm{Nb}$ vs. $\mathrm{Zr}$ (ppm) and (d) $\mathrm{Nb}$ vs. $\mathrm{La}+\mathrm{Ce}$ diagrams showing trace element AFC (assimilation-fractional crystallization) modeling, and (e) $\left({ }^{143} \mathrm{Nd} /{ }^{144} \mathrm{Nd}\right)_{\mathrm{i}}$ 
vs. $\left({ }^{87} \mathrm{Sr} /{ }^{86} \mathrm{Sr}\right)_{\mathrm{i}}$ diagram showing isotopic AFC and source mixing modeling for the volcanic rock samples of the Bafra (Samsun) area. In Fig. 12a-d, AFC curves were also shown for different values of $r$ (the ratio of the rate of assimilation to the rate of fractional crystallization process), varying from 0.2 to 0.8 , and a parental magma $\left(I \mathrm{C}_{0}\right.$; $\mathrm{La}=12.4 \mathrm{ppm}, \mathrm{Ce}=26 \mathrm{ppm}, \mathrm{Zr}=43.6 \mathrm{ppm}$ and $\mathrm{Nb}=2.1 \mathrm{ppm} ; \mathrm{CIPW}$ mineralogy= olivine:23.40, clinopyroxene:31.31, plagioclase:40.53, magnetite:4.76; Koçevyanı Basalt, Temizel and Arslan, 2008), assimilant (UCC; upper continental crust, $\mathrm{La}=30 \mathrm{ppm}, \mathrm{Ce}=64 \mathrm{ppm}, \mathrm{Zr}=190 \mathrm{ppm}$ and $\mathrm{Nb}=25 \mathrm{ppm}$, Taylor and McLennan, 1985) compositions and bulk distribution coefficients (McKenzie and O’Nions, 1991). In Fig. 12e, the representative $\mathrm{AFC}$ curves are for various combinations of a hypothetical parental magma $\left(\mathrm{IC}_{0} ;{ }^{87 / 86} \mathrm{Sr}=\right.$ 0.70286 and ${ }^{143 / 144} \mathrm{Nd}=0.512917, \mathrm{Sr}=80 \mathrm{ppm}$ and $\mathrm{Nd}=220 \mathrm{ppm}$ ), assimilant $\left(\mathrm{UCC} ;{ }^{87 / 86} \mathrm{Sr}=0.71463\right.$ and ${ }^{143 / 144} \mathrm{Nd}=0.511843$, Davies et al., 1985; $\mathrm{Sr}=26 \mathrm{ppm}$ and $\mathrm{Nd}=350 \mathrm{ppm}$, Taylor and McLennan, 1985) and bulk distribution coefficients $\left(\mathrm{D}_{\mathrm{Sr}}=0.85, \mathrm{D}_{\mathrm{Nd}}=0.10\right)$. Tick marks indicate the degree of crystallization $(F)$ and are given in intervals of 0.5 to a maximum of 0.90 ( $\mathrm{r}=0.1$ to 0.4 , for all curves). Theoretic lines of mixing model are between upper mantle $\left(\mathrm{UM} ;{ }^{87 / 86} \mathrm{Sr}=0.7025\right.$ and ${ }^{143 / 144} \mathrm{Nd}=0.5132$, Rehkamper and Hofmann, 1997; $\mathrm{Sr}=19 \mathrm{ppm}$ and $\mathrm{Nd}=190 \mathrm{ppm}$, Zindler et al., 1984) and middle/lower continental crust (MCC/LCC; ${ }^{87 / 86} \mathrm{Sr}=0.71014$ and ${ }^{143 / 144} \mathrm{Nd}=0.5111$, Ben Othman et al., 1984; $\mathrm{Sr}=300 \mathrm{ppm}$ and $\mathrm{Nd}=24 \mathrm{ppm}$, Rudnick and Fountain, 1995); GLOSS (Global Subducting Sediment) from Plank and Langmuir (1998). Tick marks indicate the degree of crystallization and are given in intervals of 0.1 to a maximum of 0.90 and $f$, fraction of component $\mathrm{UM}$ in product magma. Symbols are as in Fig. 5b.

Fig. 13. Schematic cartoon showing the favored petrogenetic evolutionary model for the parental magma (s) generation accompanied by post-collisional extension due to delamination of lithosphere, and differentiation processes in lower to upper crustal magma chambers for the Eocene volcanic and gabbroic rocks of the Bafra (Samsun) area in the Eastern Pontides. 


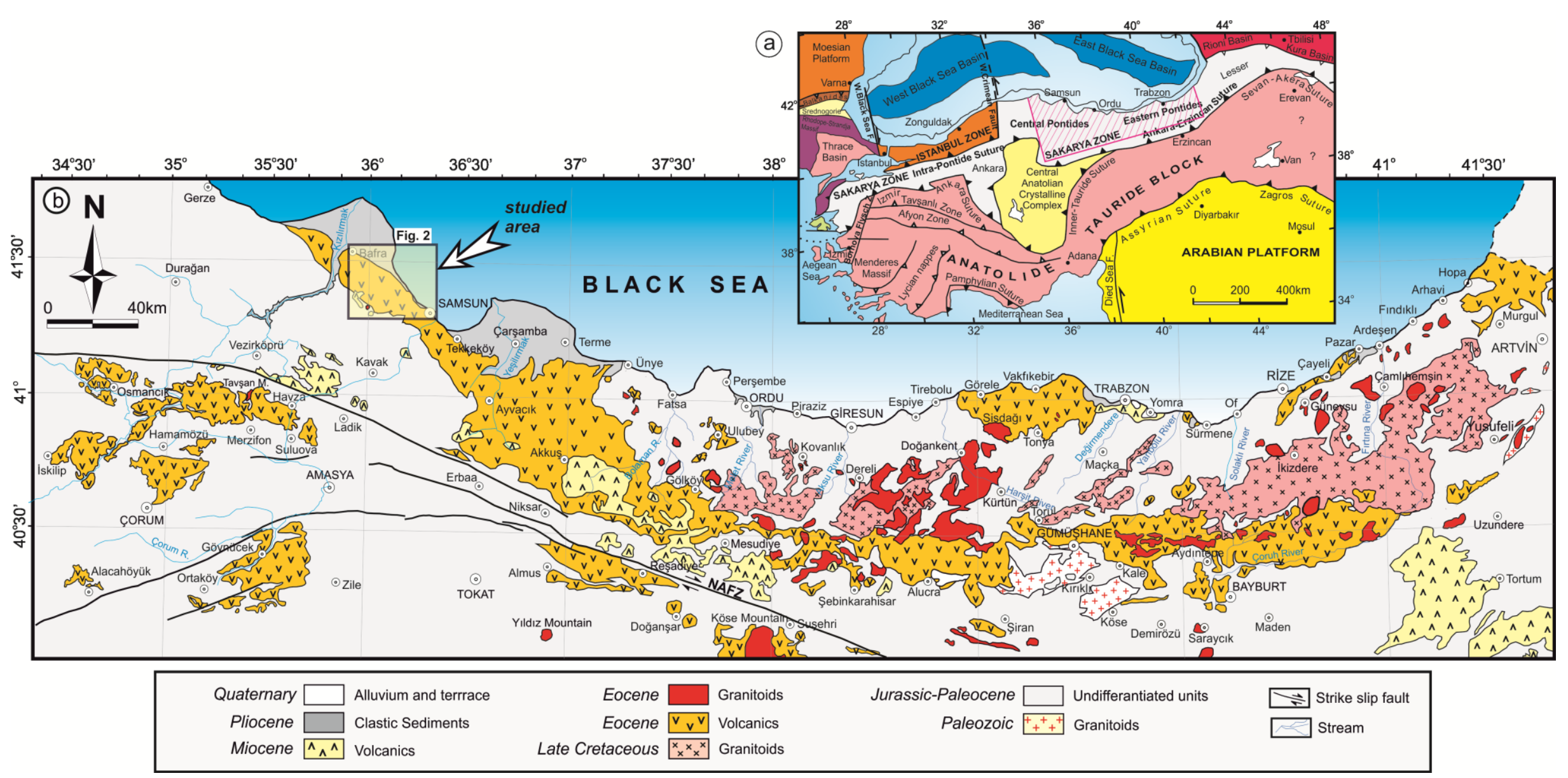

Fig. 1. 


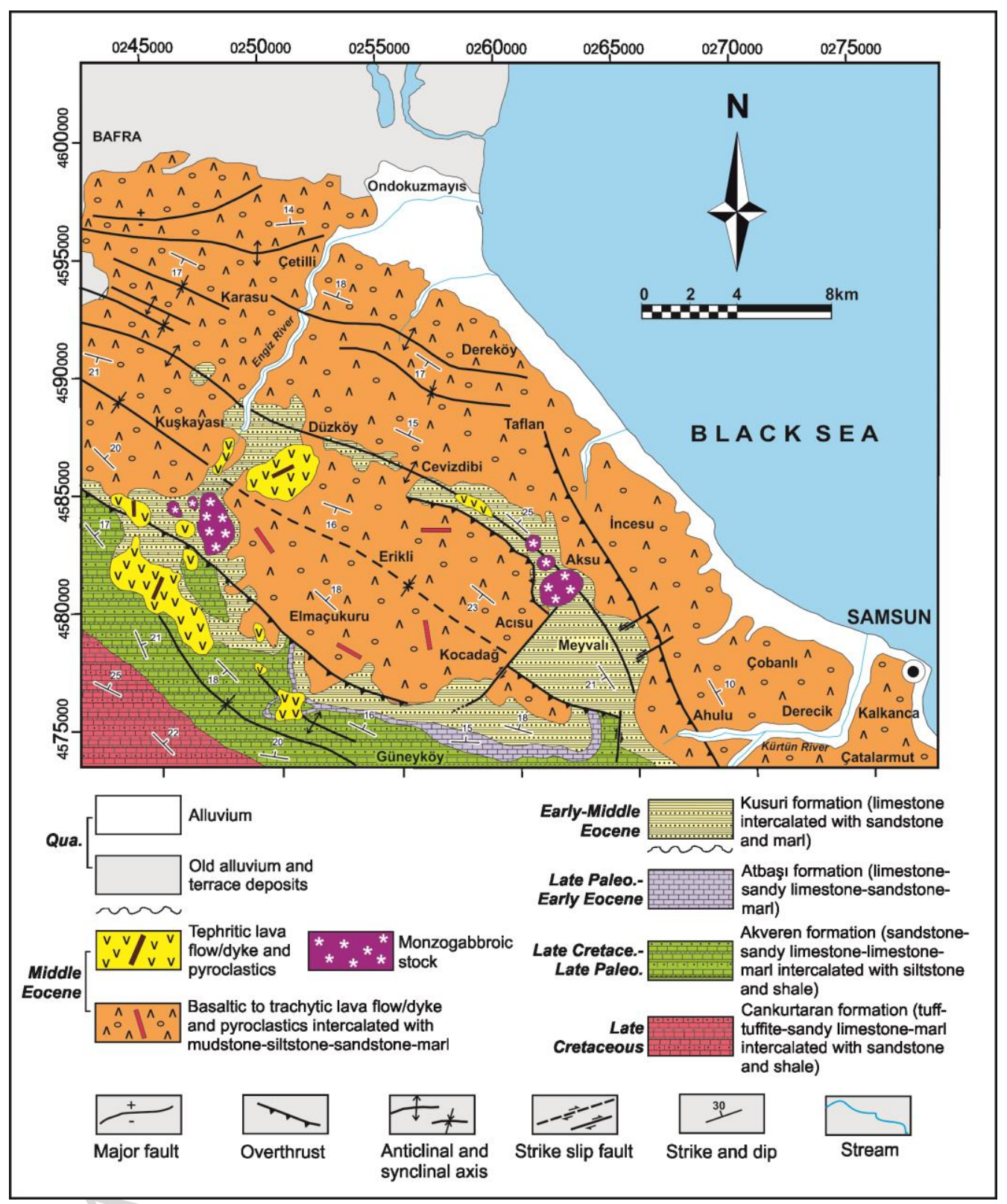

Fig. 2. 


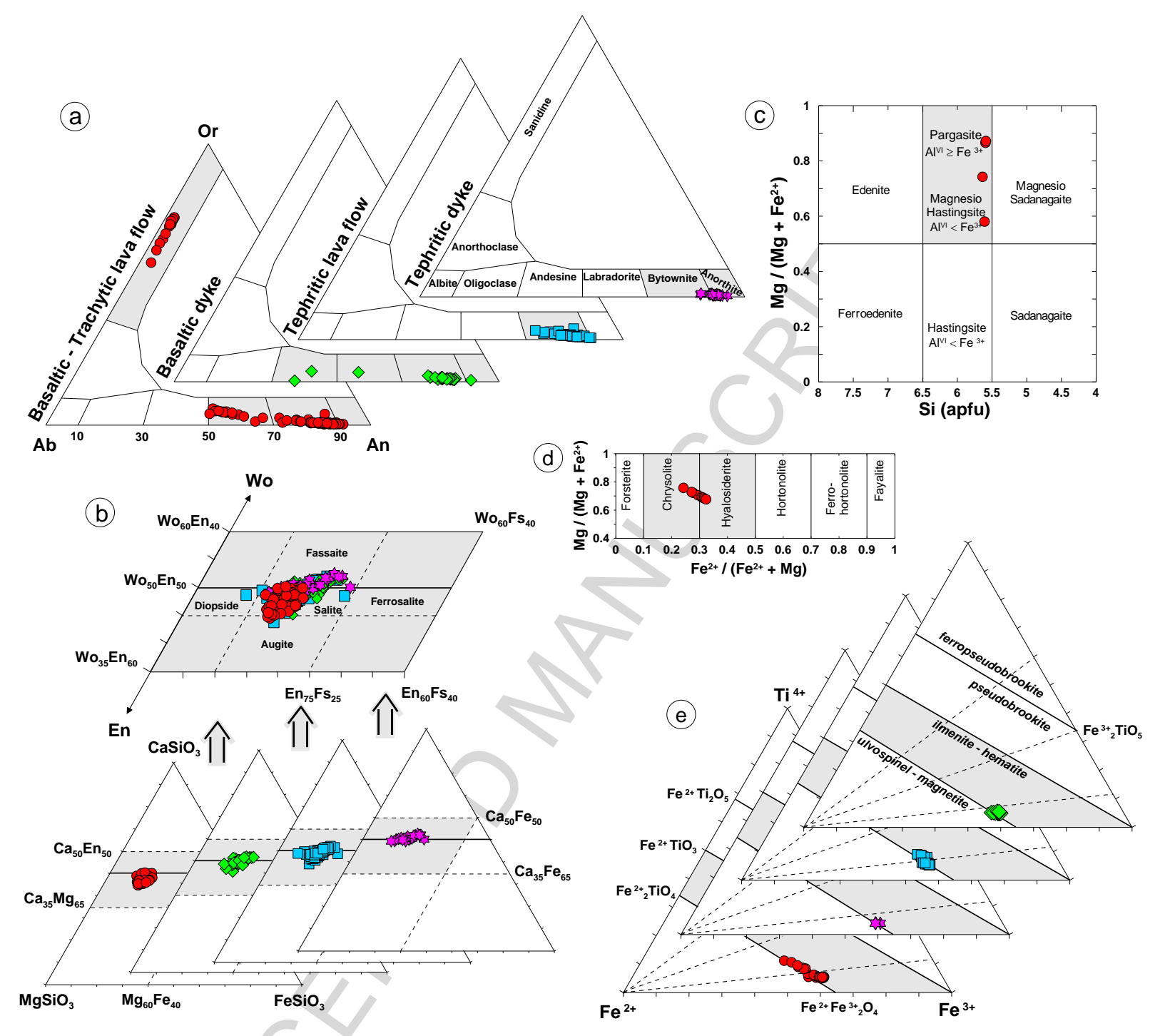

Fig. 3. 

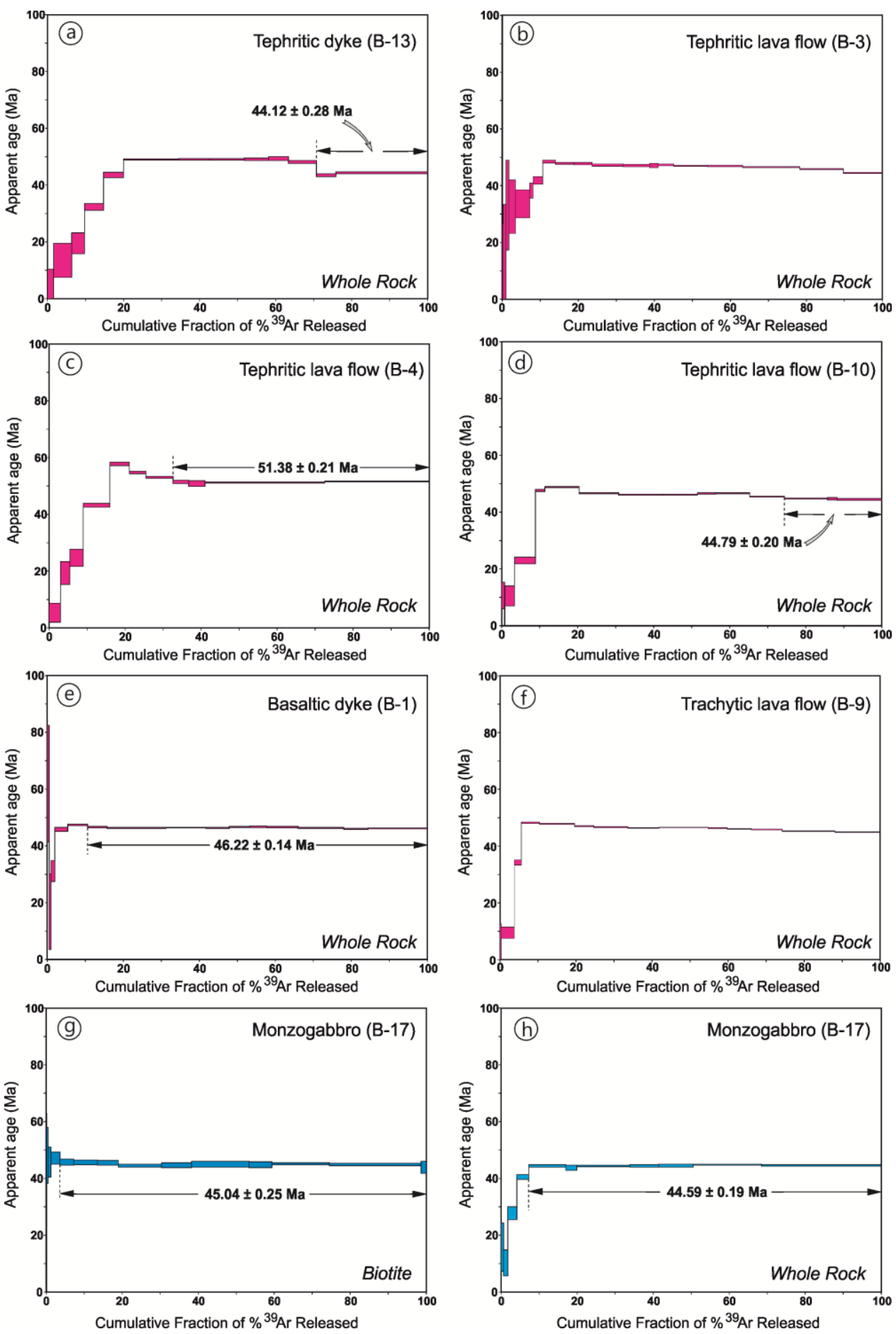

Fig. 4. 

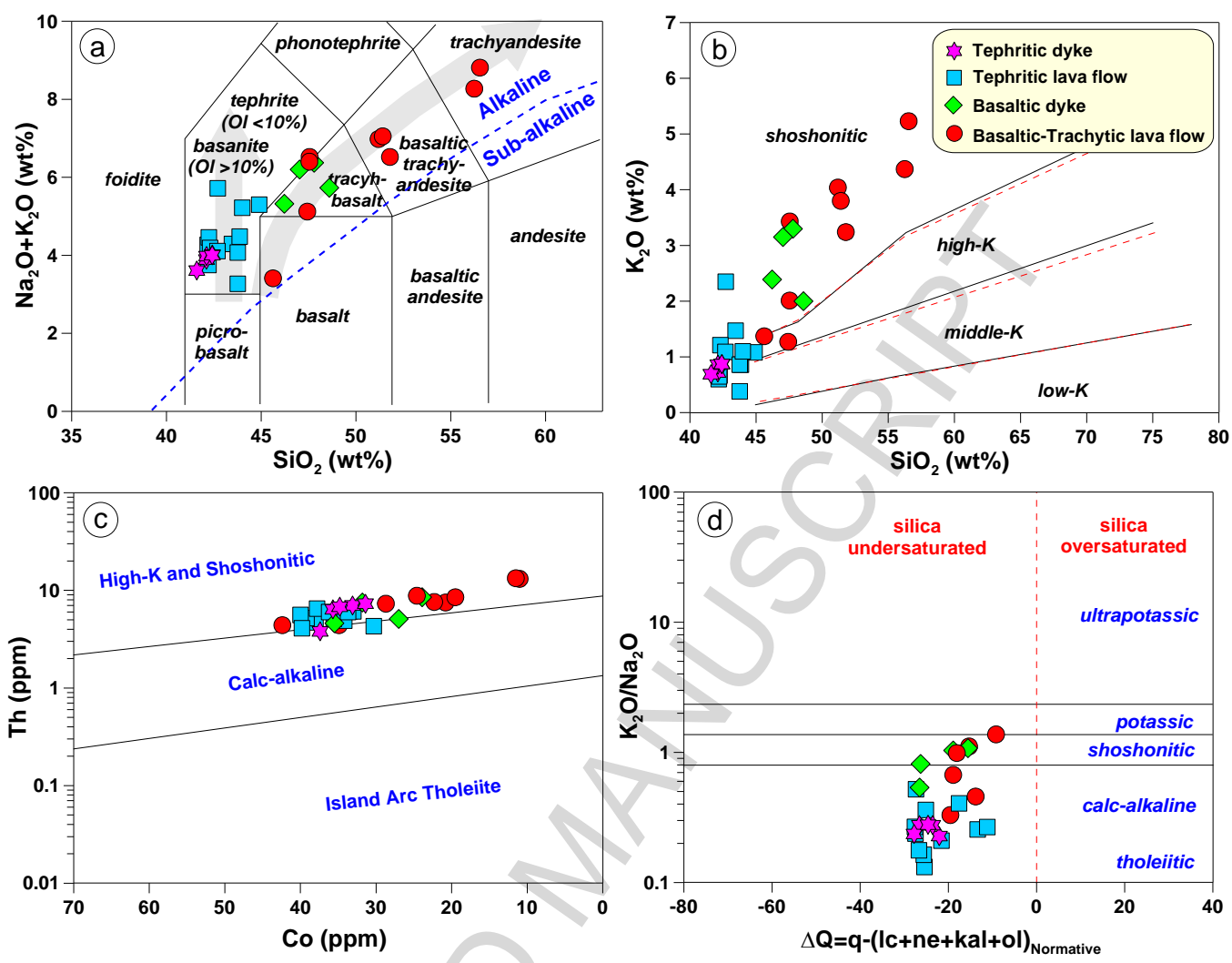

Fig. 5. 

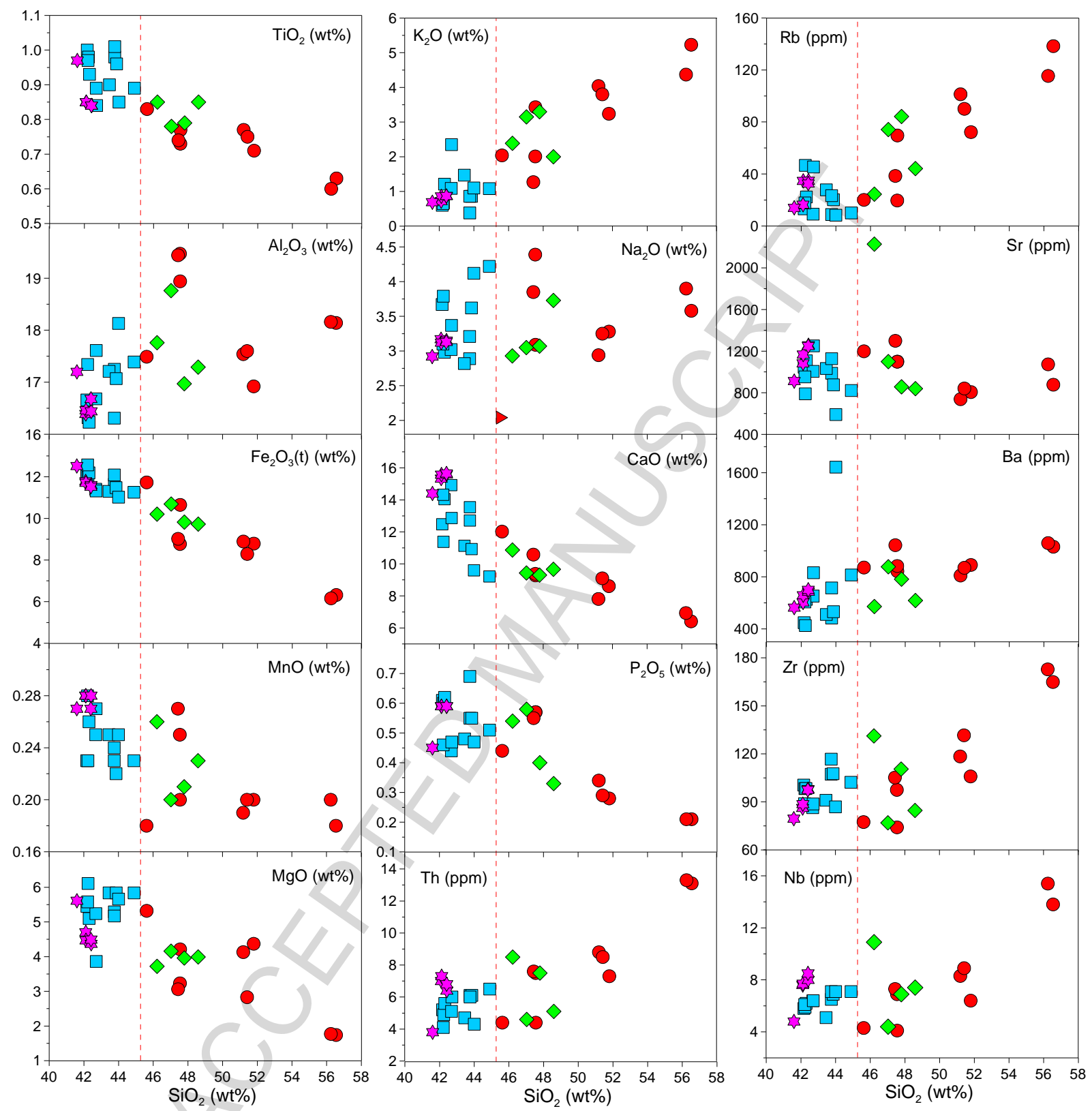

Fig. 6. 


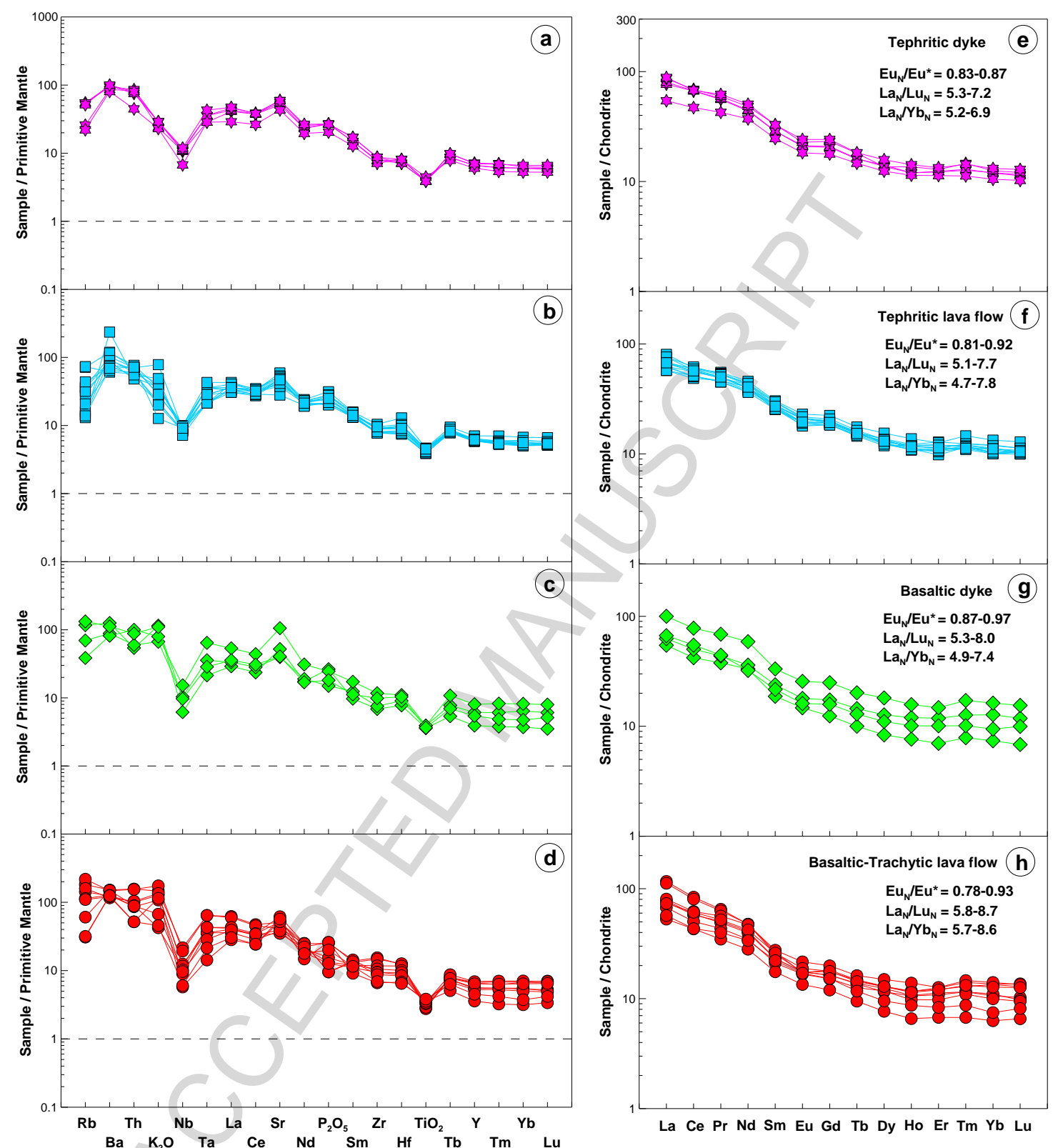

Fig. 7. 


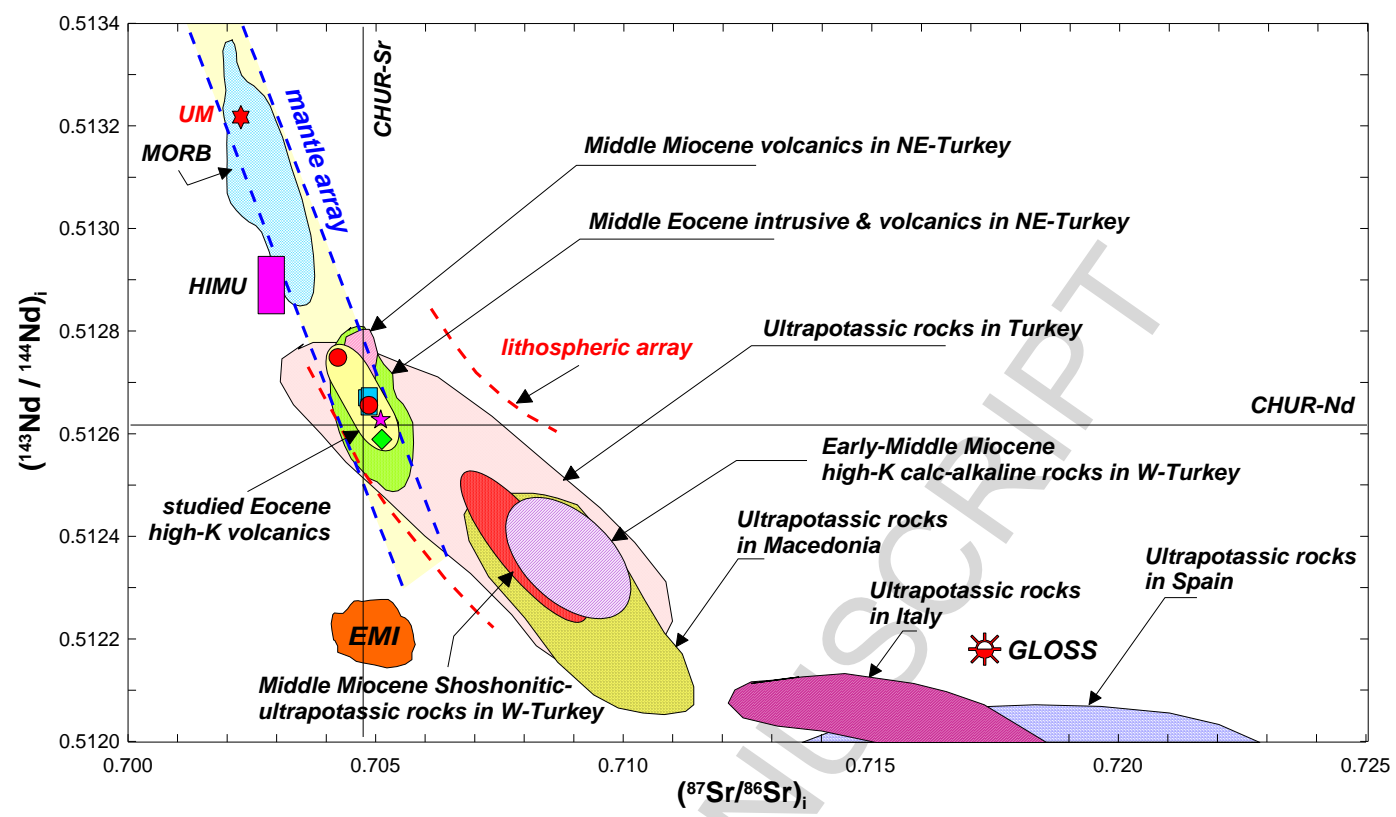

Fig. 8. 

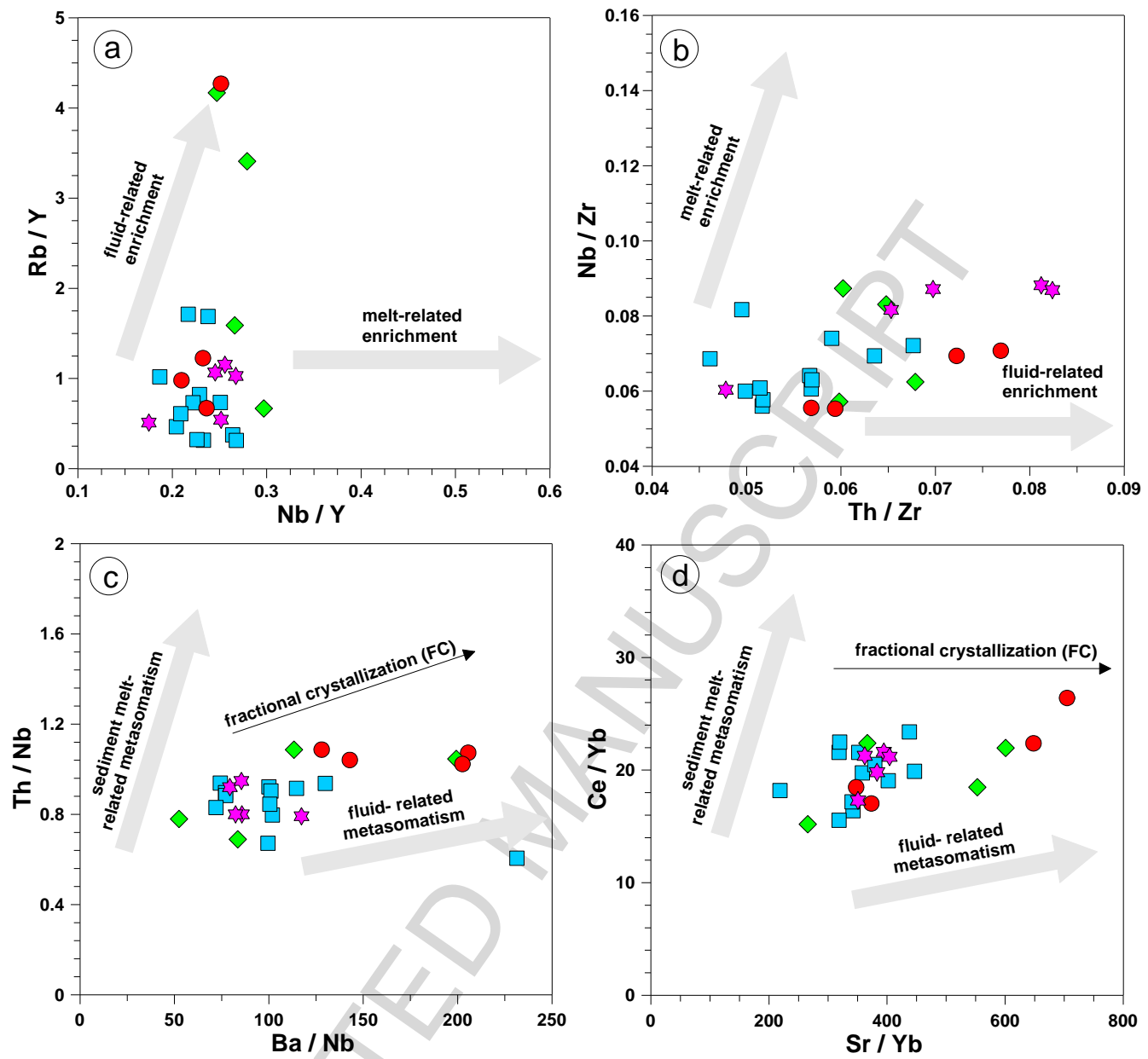

Fig. 9. 

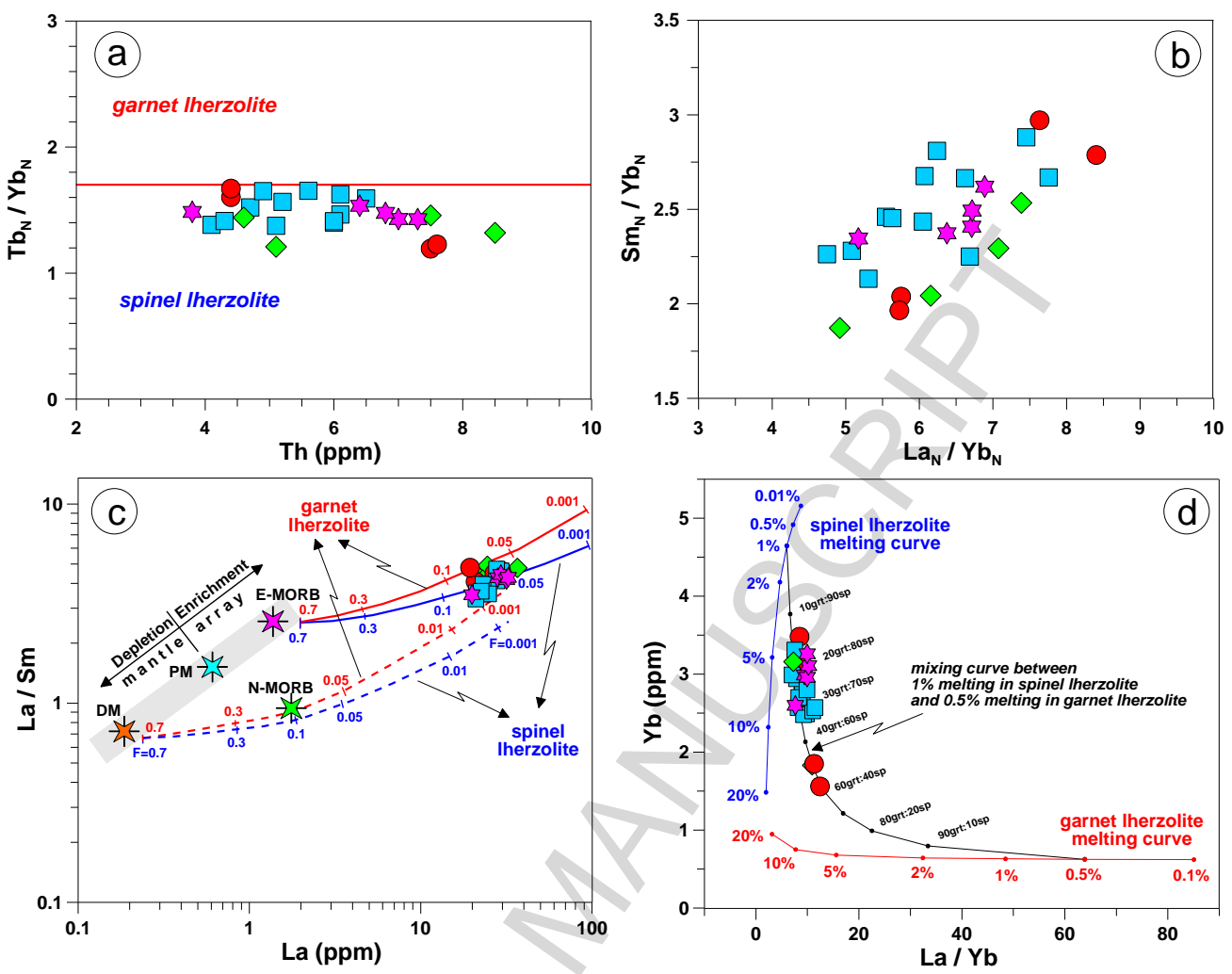

Fig. 10. 

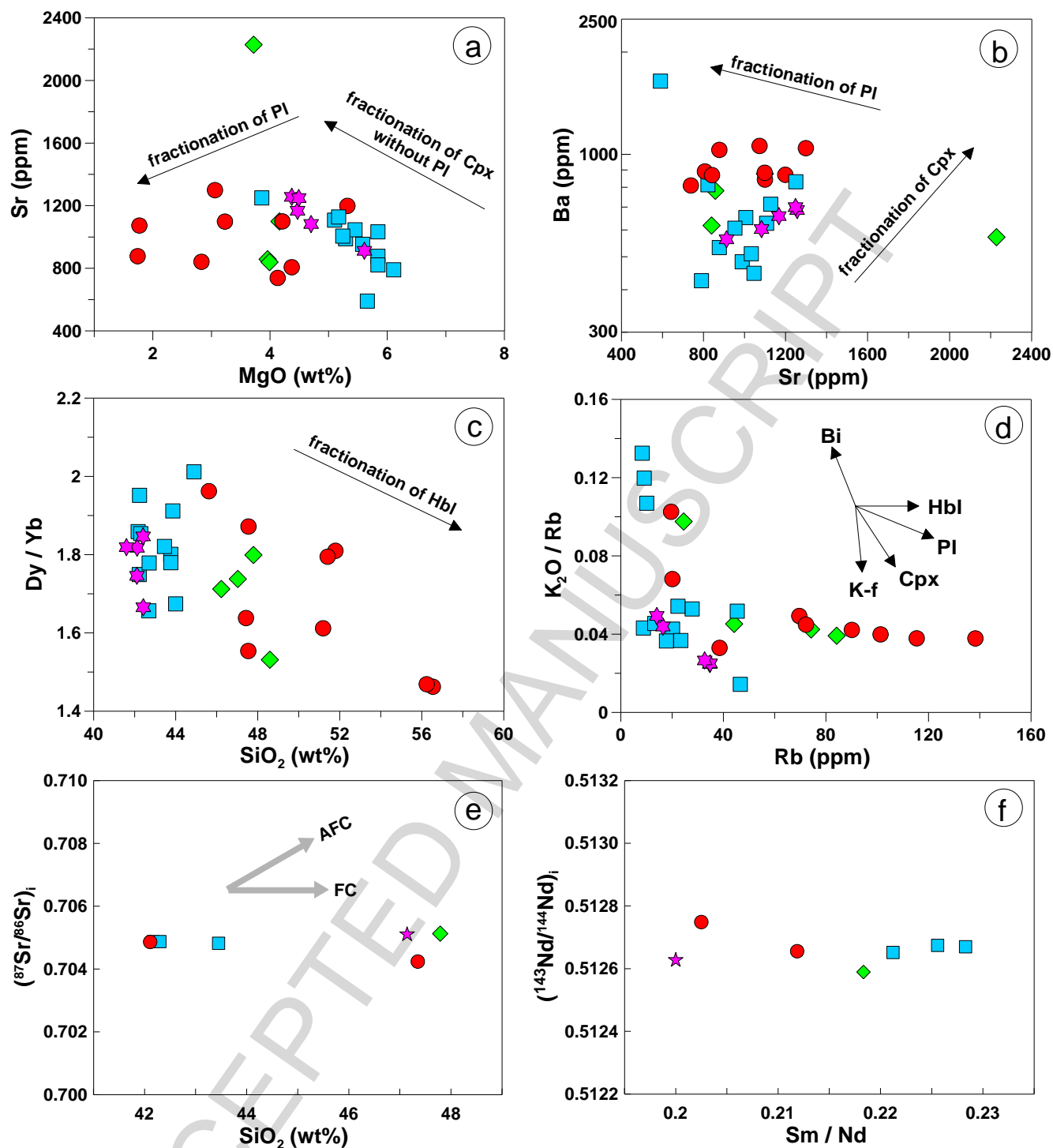

Fig. 11. 

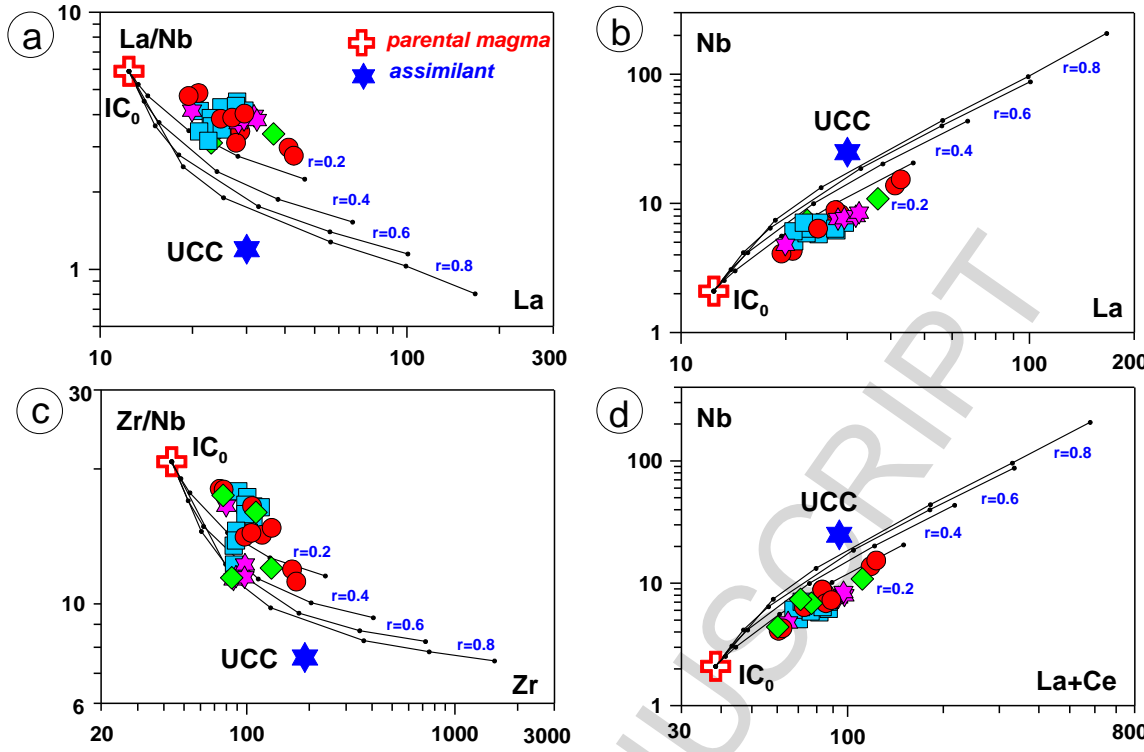

e

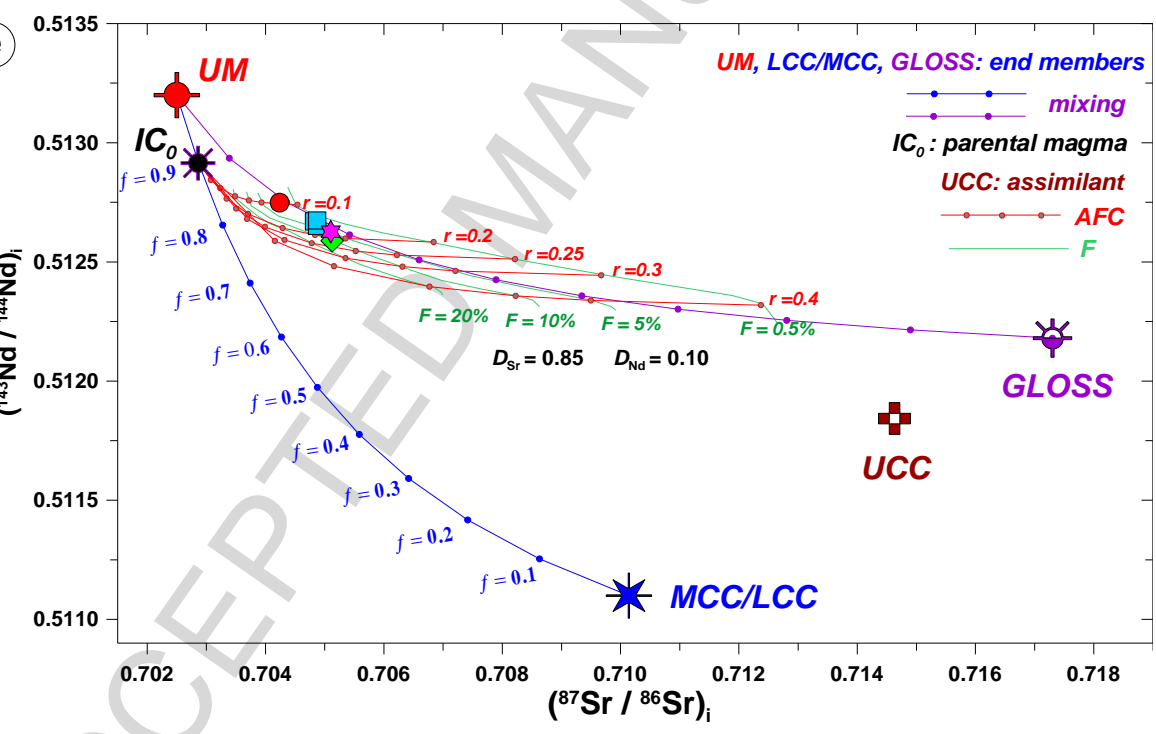

Fig. 12. 


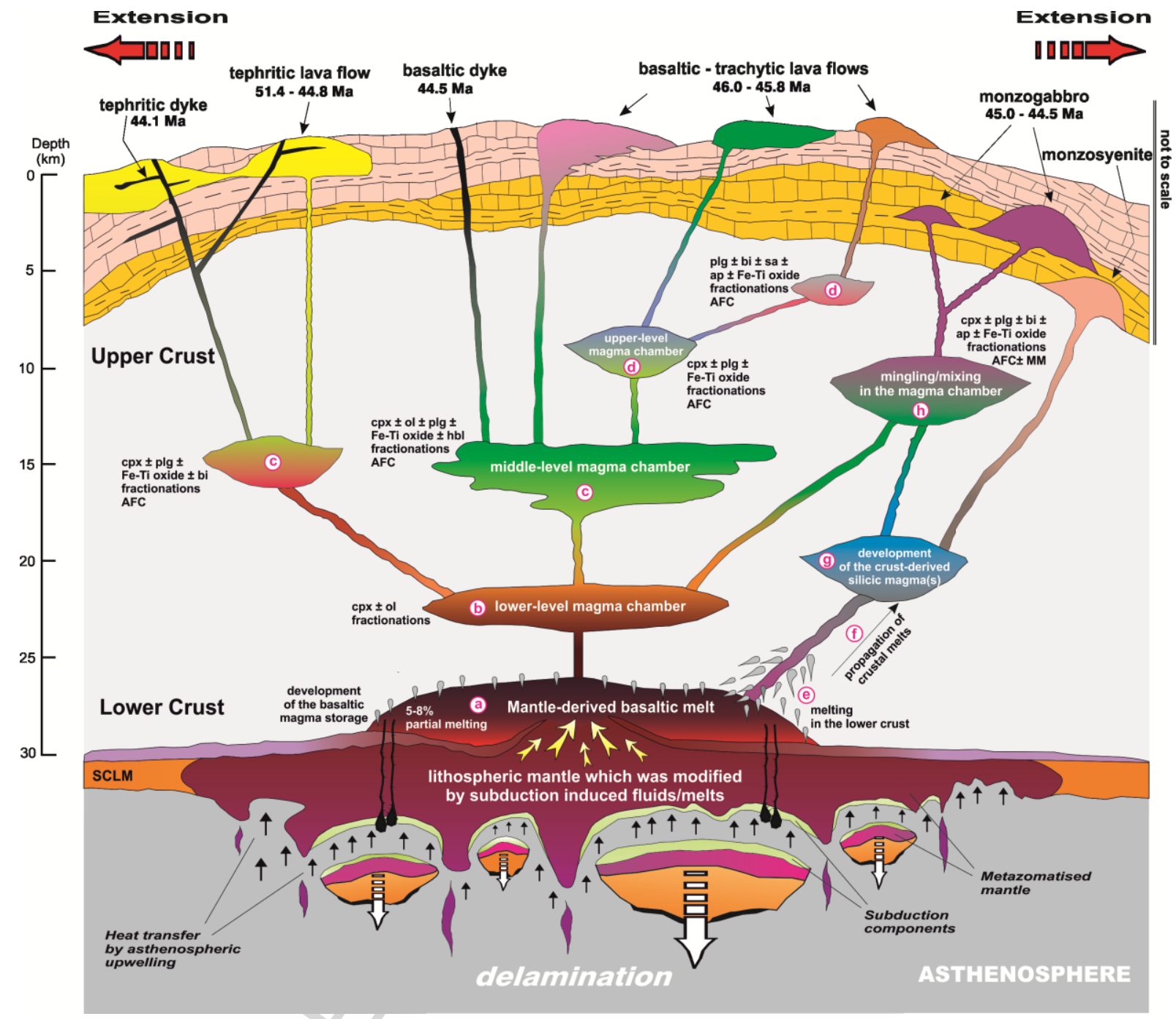

Fig. 13. 


\section{Table Captions and Tables}

Table 1. ${ }^{40} \mathrm{Ar}-{ }^{39} \mathrm{Ar}$ dating results of volcanic rocks and intusive equivalents from the Bafra (Samsun) area. ${ }^{40} \mathrm{Ar}_{\mathrm{atm}}=$ atmospheric ${ }^{40} \mathrm{Ar} .{ }^{40} \mathrm{Ar} *=$ radiogenic ${ }^{40} \mathrm{Ar} . \mathrm{Ca}=$ produced by Ca-neutron interferences. $\mathrm{K}=$ produced by K-neutron interferences. Age $(\mathrm{Ma})=$ the date is calculated using the decay constants recommended by Steiger and Jäger (1977). The errors are at the $1 \sigma$ level and do not include the error in the value of the $\mathbf{J}$ parameter. Correction factors for interfering isotopes produced by neutron irradiation in the McMaster reactor were $\left({ }^{39} \mathrm{Ar} /{ }^{37} \mathrm{Ar}\right)_{\mathrm{Ca}}=7.06 \times 10^{-4},\left({ }^{36} \mathrm{Ar}{ }^{37} \mathrm{Ar}\right)_{\mathrm{Ca}}=2.79 \times 10^{-4},\left({ }^{40} \mathrm{Ar} /{ }^{39} \mathrm{Ar}\right)_{\mathrm{K}}=2.97 \times 10^{-2}$

Table 2. Whole-rock major (wt\%), trace (ppm) and rare earth element (ppm) analyses of volcanic rock samples from the Bafra (Samsun) area.

Table 3. CIPW normative mineralogy of volcanic rock samples from the Bafra (Samsun) area.

Table 4. Sr and Nd isotopic analyses of volcanic rock samples from the Bafra (Samsun) area. 
Table 1.

\begin{tabular}{llllll}
\hline Sample no & Material & Lithology & Rock name & J parameter & Plateau age (Ma) \\
\hline B-13 & whole-rock & Tephritic dyke & tephrite & 0.00704602 & $44.12 \pm 0.28$ \\
B-3 & whole-rock & Tephritic lava flow & tephrite & 0.00702144 & $46.48 \pm 0.24 *$ \\
B-4 & whole-rock & Tephritic lava flow & tephrite & 0.00703000 & $51.38 \pm 0.21$ \\
B-10 & whole-rock & Tephritic lava flow & tephrite & 0.00704731 & $44.79 \pm 0.20$ \\
B-1 & whole-rock & Basaltic dyke & basalt & trachybasalt & 0.00526662 \\
B-9 & whole-rock & Trachytic lava flow & monzogabbro & 0.00704537 & $44.50 \pm 0.20$ \\
B-17 & biotite & intrusive equivalent & monzogabbro & 0.00704537 & $45.83 \pm 0.20 *$ \\
B-17 & whole-rock & intrusive equivalent & $45.04 \pm 0.25$ & $44.59 \pm 0.19$ \\
\hline
\end{tabular}

* The apparent ages are average mean of Ar step-heating ages for up to $60 \%$ and $70 \%$ of the gas released for each samples (B-3 and B-9) since there is no plateau age (see Fig. 4) 
Table 2.

\begin{tabular}{|c|c|c|c|c|c|c|c|c|c|c|c|c|c|c|c|c|c|c|}
\hline \multirow[b]{2}{*}{ Sample no.: } & \multirow{2}{*}{$\mathrm{dl}$} & \multicolumn{5}{|c|}{ Tephritic dyke } & \multicolumn{12}{|c|}{ Tephritic lava flow } \\
\hline & & B-13 & B-14 & B-15 & B-16 & B-28 & B-2 & B-3 & B-4 & B-5 & B-6 & B-10 & B-22 & B-33 & B-35 & B-38 & B-44 & B-47 \\
\hline $\mathrm{SiO}_{2}$ & 0.01 & 42.11 & 42.12 & 42.42 & 41.60 & 42.41 & 43.76 & 43.45 & 42.17 & 43.86 & 42.24 & 42.30 & 45.49 & 42.69 & 43.76 & 42.22 & 44.00 & 42.71 \\
\hline $\mathrm{TiO}_{2}$ & 0.01 & 0.85 & 0.85 & 0.84 & 0.97 & 0.84 & 0.98 & 0.90 & 1.00 & 0.96 & 0.98 & 0.93 & 0.89 & 0.89 & 1.01 & 0.97 & 0.85 & 0.84 \\
\hline $\mathrm{Al}_{2} \mathrm{O}_{3}$ & 0.01 & 16.39 & 16.46 & 16.44 & 17.20 & 16.68 & 17.25 & 17.21 & 16.66 & 17.07 & 16.32 & 16.23 & 16.79 & 16.68 & 16.31 & 17.34 & 18.13 & 17.61 \\
\hline $\mathrm{Fe}_{2} \mathrm{O}_{3}(\mathrm{t})$ & 0.04 & 11.78 & 11.71 & 11.60 & 12.52 & 11.53 & 11.64 & 11.30 & 12.25 & 11.48 & 11.97 & 12.19 & 11.26 & 11.40 & 12.09 & 12.57 & 11.02 & 11.32 \\
\hline $\mathrm{MnO}$ & 0.01 & 0.28 & 0.28 & 0.28 & 0.27 & 0.27 & 0.23 & 0.25 & 0.23 & 0.22 & 0.23 & 0.26 & 0.23 & 0.25 & 0.24 & 0.28 & 0.25 & 0.27 \\
\hline $\mathrm{MgO}$ & 0.01 & 4.70 & 4.47 & 4.37 & 5.61 & 4.49 & 5.29 & 5.84 & 5.45 & 5.84 & 6.11 & 5.10 & 5.84 & 5.24 & 5.17 & 5.58 & 5.66 & 3.86 \\
\hline $\mathrm{CaO}$ & 0.01 & 15.33 & 15.58 & 15.59 & 14.40 & 15.65 & 12.71 & 11.13 & 12.48 & 10.93 & 11.38 & 14.05 & 9.22 & 14.92 & 13.54 & 14.32 & 9.60 & 12.87 \\
\hline $\mathrm{Na}_{2} \mathrm{O}$ & 0.01 & 3.17 & 3.12 & 3.15 & 2.92 & 3.13 & 2.89 & 2.82 & 3.67 & 3.62 & 3.79 & 2.98 & 4.22 & 3.02 & 3.21 & 3.10 & 4.12 & 3.37 \\
\hline $\mathrm{K}_{2} \mathrm{O}$ & 0.01 & 0.72 & 0.86 & 0.87 & 0.69 & 0.87 & 0.38 & 1.47 & 0.60 & 0.86 & 0.67 & 1.21 & 1.08 & 1.09 & 0.86 & 0.65 & 1.10 & 2.35 \\
\hline $\mathrm{P}_{2} \mathrm{O}_{5}$ & 0.01 & 0.59 & 0.59 & 0.59 & 0.45 & 0.59 & 0.55 & 0.48 & 0.61 & 0.55 & 0.60 & 0.62 & 0.51 & 0.44 & 0.69 & 0.46 & 0.47 & 0.47 \\
\hline LOI & 0.01 & 3.70 & 3.60 & 3.50 & 3.00 & 3.10 & 3.90 & 4.80 & 4.50 & 4.20 & 5.40 & 3.80 & 4.10 & 3.00 & 2.70 & 2.10 & 4.40 & 3.90 \\
\hline Total & 0.01 & 99.62 & 99.64 & 99.65 & 99.63 & 99.56 & 99.58 & 99.65 & 99.62 & 99.59 & 99.69 & 99.67 & 99.63 & 99.62 & 99.58 & 99.59 & 99.60 & 99.57 \\
\hline $\mathrm{Zr}$ & 0.1 & 86.2 & 88.6 & 98.0 & 79.5 & 97.5 & 107.3 & 91.0 & 100.5 & 107.6 & 98.3 & 98.4 & 102.3 & 86.4 & 116.7 & 88.9 & 86.9 & 88.7 \\
\hline $\mathrm{Y}$ & 0.1 & 30.2 & 30.1 & 32.6 & 27.4 & 31.8 & 27.9 & 27.3 & 28.4 & 27.5 & 27.2 & 27.1 & 26.9 & 28.3 & 32.0 & 29.2 & 26.5 & 26.9 \\
\hline $\mathrm{Sr}$ & 0.5 & 1083 & 1167 & 1257 & 912 & 1249 & 988 & 1033 & 1046 & 877 & 790 & 1108 & 822 & 1006 & 1128 & 953 & 590 & 1250 \\
\hline $\mathrm{Rb}$ & 0.1 & 16.4 & 34.7 & 34.8 & 14.0 & 32.7 & 8.8 & 27.8 & 13.2 & 20.2 & 46.6 & 22.3 & 10.1 & 9.1 & 23.4 & 17.8 & 8.3 & 45.4 \\
\hline Th & 0.2 & 7.00 & 7.30 & 6.40 & 3.80 & 6.80 & 6.10 & 4.70 & 5.20 & 6.10 & 4.90 & 5.60 & 6.50 & 5.10 & 6.00 & 4.10 & 4.30 & 6.00 \\
\hline $\mathrm{Ta}$ & 0.1 & 0.40 & 0.50 & 0.50 & 0.40 & 0.60 & 0.40 & 0.30 & 0.40 & 0.30 & 0.30 & 0.30 & 0.60 & 0.50 & 0.50 & 0.40 & 0.50 & 0.50 \\
\hline V & 8.0 & 350 & 350 & 343 & 346 & 358 & 343 & 324 & 372 & 335 & 348 & 365 & 326 & 330 & 369 & 370 & 269 & 286 \\
\hline $\mathrm{Pb}$ & 0.1 & 11.3 & 11.7 & 10.7 & 7.8 & 9.5 & 7.6 & 7.3 & 5.7 & 4.6 & 5.2 & 7.7 & 5.6 & 6.9 & 6.6 & 6.5 & 5.8 & 9.9 \\
\hline $\mathrm{Ni}$ & 0.1 & 3.2 & 3.9 & 7.0 & 4.6 & 3.7 & 5.4 & 6.4 & 5.6 & 6.5 & 6.6 & 6.1 & 10.4 & 7.9 & 5.2 & 4.4 & 4.6 & 6.2 \\
\hline Co & 0.2 & 33.1 & 31.4 & 35.7 & 37.4 & 34.8 & 33.5 & 38.0 & 39.2 & 33.0 & 34.2 & 40.0 & 37.8 & 35.6 & 36.2 & 39.8 & 30.3 & 33.7 \\
\hline $\mathrm{Cr}$ & 20 & bdl & bdl & bdl & bdl & 30 & bdl & 30 & bdl & bdl & 20 & bdl & 30 & 30 & bdl & 20 & bdl & bdl \\
\hline $\mathrm{Ba}$ & 1.0 & 603 & 658 & 686 & 563 & 700 & 483 & 510 & 447 & 532 & 425 & 627 & 814 & 652 & 714 & 607 & 1643 & 831 \\
\hline $\mathrm{Nb}$ & 0.1 & 7.60 & 7.70 & 8.00 & 4.80 & 8.50 & 6.50 & 5.10 & 5.80 & 6.90 & 5.90 & 6.20 & 7.10 & 6.40 & 7.10 & 6.10 & 7.10 & 6.40 \\
\hline Hf & 0.1 & 2.50 & 2.20 & 2.20 & 2.50 & 2.50 & 2.80 & 2.60 & 3.10 & 3.20 & 3.00 & 2.80 & 2.80 & 2.40 & 4.00 & 2.50 & 2.30 & 2.40 \\
\hline $\mathrm{La}$ & 0.1 & 28.2 & 29.4 & 31.7 & 19.9 & 32.4 & 24.7 & 21.1 & 24.8 & 24.4 & 22.9 & 27.9 & 29.5 & 23.1 & 24.9 & 21.0 & 22.5 & 27.7 \\
\hline $\mathrm{Ce}$ & 0.1 & 63.6 & 64.0 & 65.9 & 45.0 & 64.6 & 54.5 & 49.0 & 56.6 & 53.7 & 53.5 & 59.2 & 57.8 & 48.2 & 56.9 & 46.5 & 49.1 & 55.7 \\
\hline $\operatorname{Pr}$ & 0.02 & 7.65 & 7.77 & 8.15 & 5.83 & 8.48 & 6.85 & 6.17 & 7.19 & 6.71 & 6.72 & 7.28 & 7.40 & 6.34 & 7.56 & 6.37 & 6.17 & 6.89 \\
\hline $\mathrm{Nd}$ & 0.3 & 31.2 & 31.7 & 34.2 & 26.4 & 35.9 & 28.8 & 25.8 & 31.1 & 30.3 & 28.4 & 30.1 & 31.2 & 28.8 & 32.5 & 27.3 & 26.6 & 28.1 \\
\hline $\mathrm{Sm}$ & 0.05 & 6.61 & 6.64 & 7.59 & 5.68 & 7.57 & 6.26 & 5.89 & 6.88 & 6.18 & 6.49 & 6.79 & 6.39 & 5.84 & 7.03 & 6.30 & 6.17 & 5.87 \\
\hline $\mathrm{Eu}$ & 0.02 & 1.85 & 1.81 & 1.98 & 1.59 & 2.10 & 1.69 & 1.66 & 1.89 & 1.66 & 1.79 & 1.85 & 1.84 & 1.72 & 2.00 & 1.80 & 1.56 & 1.59 \\
\hline Gd & 0.05 & 6.38 & 6.27 & 7.08 & 5.44 & 7.38 & 5.91 & 5.60 & 6.35 & 5.84 & 6.03 & 6.12 & 5.81 & 5.82 & 6.86 & 6.09 & 5.61 & 5.63 \\
\hline $\mathrm{Tb}$ & 0.01 & 0.94 & 0.93 & 1.05 & 0.85 & 1.06 & 0.89 & 0.86 & 0.95 & 0.89 & 0.90 & 0.92 & 0.90 & 0.89 & 1.02 & 0.91 & 0.84 & 0.87 \\
\hline Dy & 0.05 & 5.22 & 5.38 & 5.18 & 4.73 & 6.02 & 4.97 & 4.68 & 5.13 & 4.76 & 4.84 & 4.69 & 5.17 & 4.87 & 5.89 & 5.23 & 4.52 & 4.98 \\
\hline Но & 0.02 & 1.02 & 1.02 & 1.16 & 0.97 & 1.21 & 0.99 & 0.93 & 1.01 & 0.96 & 0.92 & 0.93 & 0.94 & 1.01 & 1.17 & 1.04 & 1.02 & 0.99 \\
\hline $\mathrm{Er}$ & 0.03 & 3.04 & 3.08 & 3.20 & 2.82 & 3.33 & 2.83 & 2.67 & 2.99 & 2.69 & 2.82 & 2.61 & 2.44 & 2.80 & 3.14 & 3.19 & 3.02 & 2.86 \\
\hline $\mathrm{Tm}$ & 0.01 & 0.45 & 0.46 & 0.52 & 0.40 & 0.51 & 0.40 & 0.41 & 0.42 & 0.42 & 0.39 & 0.40 & 0.41 & 0.44 & 0.52 & 0.44 & 0.41 & 0.43 \\
\hline $\mathrm{Yb}$ & 0.05 & 2.99 & 2.96 & 3.11 & 2.60 & 3.26 & 2.76 & 2.57 & 2.76 & 2.49 & 2.48 & 2.53 & 2.57 & 2.94 & 3.31 & 2.99 & 2.70 & 2.80 \\
\hline $\mathrm{Lu}$ & 0.01 & 0.44 & 0.43 & 0.46 & 0.39 & 0.49 & 0.40 & 0.39 & 0.41 & 0.40 & 0.38 & 0.38 & 0.40 & 0.43 & 0.49 & 0.43 & 0.39 & 0.39 \\
\hline $\mathrm{Eu}_{\mathrm{N}} / \mathrm{Eu}^{*}$ & & 0.87 & 0.86 & 0.83 & 0.87 & 0.86 & 0.85 & 0.88 & 0.87 & 0.84 & 0.87 & 0.88 & 0.92 & 0.90 & 0.88 & 0.89 & 0.81 & 0.85 \\
\hline $\mathrm{La}_{N} / \mathrm{Lu}_{\mathrm{N}}$ & & 6.65 & 7.10 & 7.15 & 5.30 & 6.86 & 6.41 & 5.62 & 6.28 & 6.33 & 6.26 & 7.62 & 7.66 & 5.58 & 5.28 & 5.07 & 5.99 & 7.37 \\
\hline $\mathrm{La}_{\mathrm{N}} / \mathrm{Yb}_{\mathrm{N}}$ & & 6.37 & 6.71 & 6.89 & 5.17 & 6.72 & 6.05 & 5.55 & 6.07 & 6.62 & 6.24 & 7.45 & 7.76 & 5.31 & 5.08 & 4.75 & 5.63 & 6.69 \\
\hline $\mathrm{Mg \#}$ & & 28.5 & 27.6 & 27.4 & 30.9 & 28.0 & 31.2 & 34.1 & 30.8 & 33.7 & 33.8 & 29.5 & 34.2 & 31.5 & 30.0 & 30.7 & 33.9 & 25.4 \\
\hline AI & & 2.74 & 2.83 & 2.75 & 2.65 & 2.74 & 1.51 & 2.64 & 3.10 & 2.68 & 3.26 & 2.97 & 3.12 & 2.74 & 2.31 & 2.56 & 3.37 & 4.35 \\
\hline
\end{tabular}

$\mathrm{Fe}_{2} \mathrm{O}_{3}(\mathrm{t})$. total iron as $\mathrm{Fe}_{2} \mathrm{O}_{3}$; LOI: loss on ignition. $\mathrm{Mg} \#$ (Mg-number) $=100 \times \mathrm{MgO} /\left(\mathrm{MgO}+\mathrm{Fe}_{2} \mathrm{O}_{3}\right.$ (t)). Symbols:bdl:below detection limit,

dl: detection limit. Alkalinity Index $(\mathrm{AI})=\left(\mathrm{Na}_{2} \mathrm{O}+\mathrm{K}_{2} \mathrm{O}\right)-\left(0.37 \times \mathrm{SiO}_{2}-14.43\right)$ 
Table 2 continued.

\begin{tabular}{|c|c|c|c|c|c|c|c|c|c|c|c|c|c|c|}
\hline \multirow[b]{2}{*}{ Sample no.: } & \multirow{2}{*}{$\mathrm{dl}$} & \multicolumn{4}{|c|}{ Basaltic dyke } & \multicolumn{9}{|c|}{ Basaltic-trachytic lava flow } \\
\hline & & B-1 & B-25 & $\mathrm{B}-30$ & B-34 & B-9 & B-11 & B-20 & B-26 & B-40 & B-41 & B-43 & B-46 & B-52 \\
\hline $\mathrm{SiO}_{2}$ & 0.01 & 47.79 & 46.22 & 48.59 & 47.03 & 47.35 & 47.14 & 45.32 & 47.23 & 51.79 & 56.54 & 56.24 & 51.19 & 51.41 \\
\hline $\mathrm{TiO}_{2}$ & 0.01 & 0.79 & 0.85 & 0.85 & 0.78 & 0.77 & 0.73 & 0.83 & 0.74 & 0.71 & 0.63 & 0.60 & 0.77 & 0.75 \\
\hline $\mathrm{Al}_{2} \mathrm{O}_{3}$ & 0.01 & 16.97 & 17.76 & 17.29 & 18.76 & 18.94 & 19.47 & 17.49 & 19.44 & 16.92 & 18.14 & 18.16 & 17.54 & 17.60 \\
\hline $\mathrm{Fe}_{2} \mathrm{O}_{3}(\mathrm{t})$ & 0.04 & 9.82 & 10.20 & 9.73 & 10.69 & 10.65 & 8.77 & 11.73 & 9.02 & 8.79 & 6.32 & 6.16 & 8.89 & 8.29 \\
\hline $\mathrm{MnO}$ & 0.01 & 0.21 & 0.26 & 0.23 & 0.20 & 0.20 & 0.25 & 0.18 & 0.27 & 0.20 & 0.18 & 0.20 & 0.19 & 0.20 \\
\hline $\mathrm{MgO}$ & 0.01 & 3.96 & 3.72 & 3.99 & 4.16 & 4.21 & 3.23 & 5.32 & 3.06 & 4.37 & 1.74 & 1.77 & 4.13 & 2.83 \\
\hline $\mathrm{CaO}$ & 0.01 & 9.30 & 10.87 & 9.66 & 9.43 & 9.28 & 9.38 & 12.02 & 10.58 & 8.61 & 6.41 & 6.93 & 7.81 & 9.10 \\
\hline $\mathrm{Na}_{2} \mathrm{O}$ & 0.01 & 3.07 & 2.93 & 3.73 & 3.05 & 3.09 & 4.49 & 2.04 & 385 & 3.28 & 3.58 & 3.90 & 2.94 & 3.25 \\
\hline $\mathrm{K}_{2} \mathrm{O}$ & 0.01 & 3.30 & 2.39 & 2.00 & 3.45 & 3.43 & 2.01 & 1.37 & 1.27 & 3.24 & 5.23 & 4.37 & 4.04 & 3.80 \\
\hline $\mathrm{P}_{2} \mathrm{O}_{5}$ & 0.01 & 0.40 & 0.54 & 0.33 & 0.58 & 0.57 & 0.57 & 0.44 & 0.55 & 0.28 & 0.21 & 0.21 & 0.34 & 0.29 \\
\hline LOI & 0.01 & 4.10 & 3.80 & 3.30 & 1.50 & 1.10 & 3.60 & 2.80 & 3.60 & 1.50 & 0.70 & 1.10 & 1.90 & 2.20 \\
\hline Total & 0.01 & 99.71 & 99.54 & 99.70 & 99.63 & 99.59 & 99.64 & 99.54 & 99.61 & 99.69 & 99.68 & 99.64 & 99.74 & 99.72 \\
\hline $\mathrm{Zr}$ & 0.1 & 110.5 & 131.2 & 84.7 & 76.9 & 74.1 & 97.5 & 77.4 & 105.2 & 105.9 & 164.9 & 172.8 & 118.4 & 131.6 \\
\hline Y & 0.1 & 24.7 & 36.7 & 27.8 & 17.8 & 16.3 & 29.2 & 20.5 & 31.4 & 24.0 & 30.0 & 30.7 & 24.9 & 25.5 \\
\hline $\mathrm{Sr}$ & 0.5 & 857 & 2228 & 839 & 1099 & 1100 & 1098 & 1199 & 1299 & 807 & 877 & 1073 & 738 & 841 \\
\hline $\mathrm{Rb}$ & 0.1 & 84.2 & 24.5 & 44.2 & 74.2 & 69.6 & 19.6 & 20.1 & 38.5 & 72.2 & 138.3 & 115.4 & 101.3 & 90.1 \\
\hline Th & 0.2 & 7.50 & 8.50 & 5.10 & 4.60 & 4.40 & 7.50 & 4.40 & 7.60 & 7.30 & 13.10 & 13.30 & 8.80 & 8.50 \\
\hline $\mathrm{Ta}$ & 0.1 & 0.40 & 0.90 & 0.50 & 0.30 & 0.20 & 0.40 & 0.30 & 0.60 & 0.50 & 0.90 & 0.90 & 0.60 & 0.50 \\
\hline V & 8.0 & 278 & 284 & 273 & 277 & 266 & 219 & 341 & 228 & 269 & 130 & 130 & 229 & 232 \\
\hline $\mathrm{Pb}$ & 0.1 & 7.2 & 3.7 & 4.4 & 57 & 6.4 & 11.6 & 7.2 & 12.9 & 1.9 & 2.7 & 15.3 & 5.0 & 3.9 \\
\hline $\mathrm{Ni}$ & 0.1 & 7.5 & 2.0 & 5.2 & 11.9 & 10.5 & 2.0 & 11.6 & 2.7 & 9.5 & 2.0 & 4.5 & 5.7 & 4.8 \\
\hline Co & 0.2 & 31.8 & 23.9 & 27.0 & & 34.9 & 20.8 & 42.4 & 22.3 & 28.7 & 11.0 & 11.5 & 24.6 & 19.5 \\
\hline $\mathrm{Cr}$ & 20 & 20 & bdl & bdl & 70 & 70 & bdl & 80 & 20 & 30 & bdl & bdl & 20 & bdl \\
\hline $\mathrm{Ba}$ & 1.0 & 782 & 571 & 618 & 877 & 843 & 883 & 871 & 1043 & 891 & 1031 & 1059 & 810 & 869 \\
\hline $\mathrm{Nb}$ & 0.1 & 6.90 & 10.90 & 7.40 & 4.40 & 4.10 & 6.90 & 4.30 & 7.30 & 6.40 & 13.80 & 15.40 & 8.30 & 8.90 \\
\hline $\mathrm{Hf}$ & 0.1 & 3.20 & 3.40 & 2.80 & 2.40 & 2.10 & 2.60 & 2.00 & 2.90 & 2.70 & 3.90 & 3.80 & 3.10 & 3.60 \\
\hline $\mathrm{La}$ & 0.1 & 24.5 & 36.7 & 23.0 & 20.0 & 19.4 & 26.9 & 20.9 & 29.5 & 24.7 & 41.1 & 42.7 & 28.6 & 27.7 \\
\hline $\mathrm{Ce}$ & 0.1 & 52.4 & & 48.0 & 40.2 & 41.2 & 58.4 & 41.4 & 59.3 & 48.1 & 76.9 & 80.2 & 56.1 & 55.4 \\
\hline $\operatorname{Pr}$ & 0.02 & 6.08 & 9.42 & 5.97 & 5.17 & 4.76 & 7.14 & 5.46 & 7.73 & 5.95 & 8.61 & 8.90 & 6.71 & 6.90 \\
\hline $\mathrm{Nd}$ & 0.3 & 22.9 & 41.8 & 25.6 & 23.6 & 20.0 & 30.0 & 24.0 & 33.4 & 24.7 & 33.8 & 33.8 & 28.2 & 29.1 \\
\hline $\mathrm{Sm}$ & 0.05 & 5.00 & 7.67 & 5.51 & 4.32 & 4.05 & 6.00 & 5.12 & 6.37 & 4.88 & 5.87 & 6.11 & 5.33 & 5.35 \\
\hline $\mathrm{Eu}$ & 0.02 & 1.40 & 2.23 & 1.56 & 1.28 & 1.17 & 1.64 & 1.48 & 1.88 & 1.45 & 1.52 & 1.49 & 1.52 & 1.52 \\
\hline $\mathrm{Gd}$ & 0.05 & 4.85 & 7.62 & 5.31 & 3.80 & 3.66 & 5.42 & 4.66 & 6.09 & 4.64 & 5.39 & 5.58 & 5.02 & 4.99 \\
\hline $\mathrm{Tb}$ & 0.01 & 0.75 & 1.17 & 0.84 & 0.58 & 0.55 & 0.83 & 0.68 & 0.94 & 0.73 & 0.85 & 0.86 & 0.79 & 0.80 \\
\hline Dy & 0.05 & 4.21 & 6.90 & 4.84 & 3.18 & 2.92 & 4.91 & 3.63 & 5.70 & 4.47 & 4.87 & 4.95 & 4.40 & 4.72 \\
\hline Ho & 0.02 & 0.86 & 1.34 & 1.02 & 0.65 & 0.56 & 0.97 & 0.74 & 1.18 & 0.83 & 1.00 & 0.99 & 0.90 & 0.91 \\
\hline $\mathrm{Er}$ & 0.03 & 2.51 & 3.68 & 2.95 & 1.74 & 1.68 & 2.99 & 2.07 & 3.15 & 2.43 & 3.01 & 3.12 & 2.70 & 2.80 \\
\hline $\mathrm{Tm}$ & 0.01 & 0.36 & 0.61 & 0.45 & 0.28 & 0.24 & 0.47 & 0.31 & 0.52 & 0.39 & 0.46 & 0.50 & 0.41 & 0.41 \\
\hline $\mathrm{Yb}$ & 0.05 & 2.34 & 4.03 & 3.16 & 1.83 & 1.56 & 3.16 & 1.85 & 3.48 & 2.47 & 3.33 & 3.37 & 2.73 & 2.63 \\
\hline $\mathrm{Lu}$ & 0.01 & 0.38 & 0.59 & 0.45 & 0.26 & 0.25 & 0.48 & 0.31 & 0.51 & 0.36 & 0.49 & 0.52 & 0.37 & 0.39 \\
\hline $\mathrm{Eu}_{N} / \mathrm{Eu}^{*}$ & & 0.87 & 0.89 & 0.88 & 0.97 & 0.93 & 0.88 & 0.93 & 0.92 & 0.93 & 0.83 & 0.78 & 0.90 & 0.90 \\
\hline $\mathrm{La}_{N} / \mathrm{Lu}_{\mathrm{N}}$ & & 6.69 & 6.46 & 5.31 & 7.99 & 8.06 & 5.82 & 7.00 & 6.00 & 7.12 & 8.71 & 8.52 & 8.02 & 7.37 \\
\hline $\mathrm{La}_{N} / \mathrm{Yb}_{\mathrm{N}}$ & & 7.08 & 6.15 & 4.92 & 7.39 & 8.40 & 5.75 & 7.63 & 5.73 & 6.76 & 8.34 & 8.56 & 7.08 & 7.12 \\
\hline Mg\# & & 28.7 & 26.7 & 29.1 & 28.0 & 28.3 & 26.9 & 31.2 & 25.3 & 33.2 & 21.6 & 22.3 & 31.7 & 25.4 \\
\hline AI & & 3.12 & 2.65 & 2.18 & 3.23 & 3.36 & 3.24 & 0.96 & 2.00 & 1.79 & 2.32 & 1.89 & 2.47 & 2.46 \\
\hline
\end{tabular}

$\mathrm{Fe}_{2} \mathrm{O}_{3}(\mathrm{t})$. total iron as $\mathrm{Fe}_{2} \mathrm{O}_{3}$; LOI: loss on ignition. $\mathrm{Mg} \#$ (Mg-number) $=100 \times \mathrm{MgO} /\left(\mathrm{MgO}+\mathrm{Fe}_{2} \mathrm{O}_{3}(\mathrm{t})\right)$. Symbols:bdl:below detection limit, dl: detection limit. Alkalinity Index $(\mathrm{AI})=\left(\mathrm{Na}_{2} \mathrm{O}+\mathrm{K}_{2} \mathrm{O}\right)-\left(0.37 \times \mathrm{SiO}_{2}-14.43\right)$ 
Table 3.

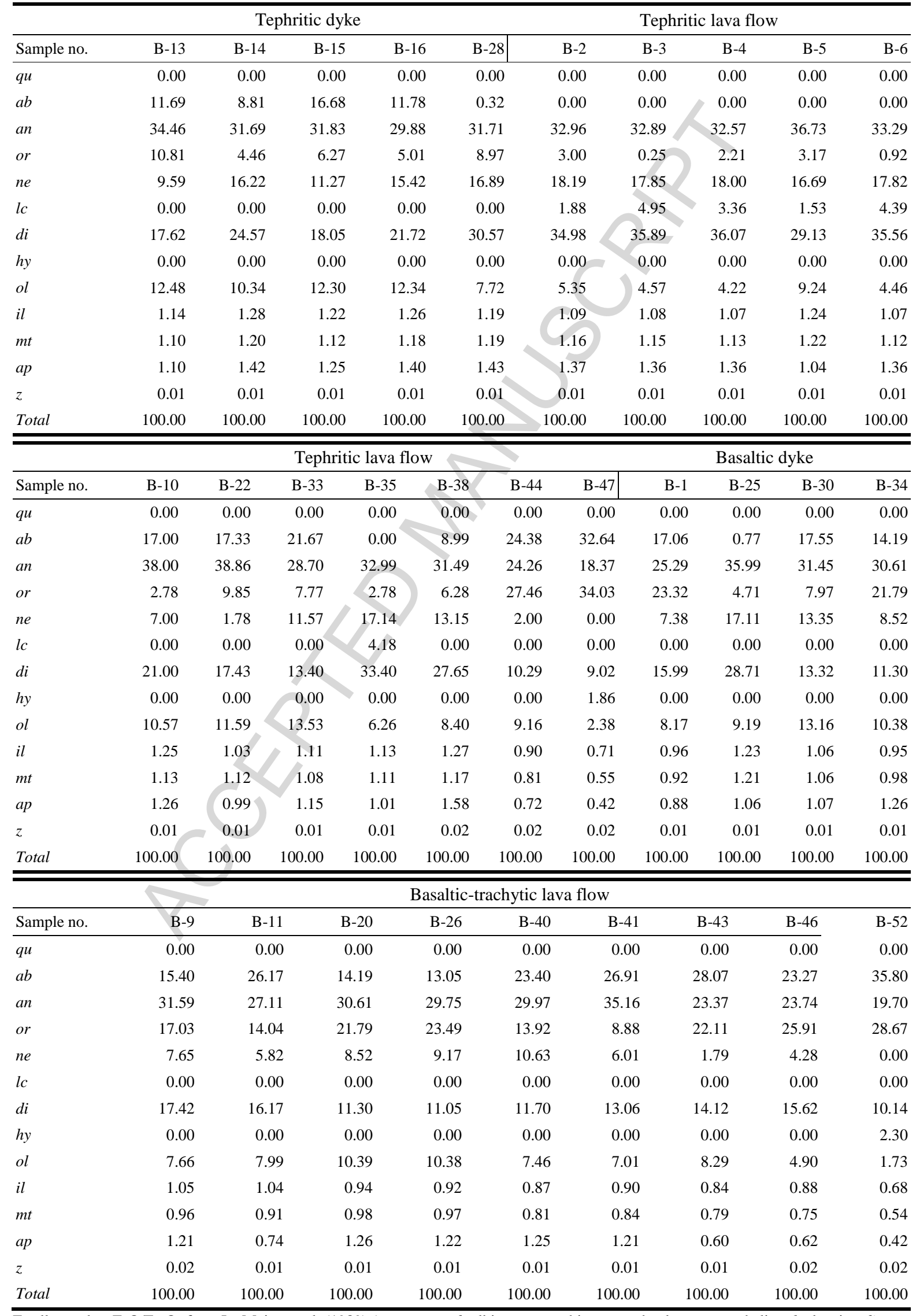

$\mathrm{Fe}$ allocated as $\mathrm{FeO} / \mathrm{Fe}_{2} \mathrm{O}_{3}$ from Le Maitre et al. (1989) (qu: quartz, ab:albite, an:anorthite, or: orthoclase, $n e$ : nepheline, $l c$ : leucite, $d i$ :

diopsite, $h y$ : hypersthene, ol: olivine, $i l$ : ilmenite, $m t$ : magnetite, ap: apatite, $z$ : zircon) 
Table 4.

\begin{tabular}{|c|c|c|c|c|c|c|c|c|c|c|c|c|c|c|c|c|c|c|}
\hline $\begin{array}{l}\text { Sample } \\
\text { no. }\end{array}$ & $\begin{array}{l}\text { Age } \\
(\mathrm{Ma}) \\
\end{array}$ & $\begin{array}{c}\mathrm{Rb} \\
(\mathrm{ppm})\end{array}$ & $\begin{array}{c}\mathrm{Sr} \\
(\mathrm{ppm})\end{array}$ & ${ }^{87} \mathrm{Rb} /{ }^{86} \mathrm{Sr}$ & ${ }^{87} \mathrm{Sr} /{ }^{86} \mathrm{Sr}$ & $2 \sigma_{\mathrm{m}}$ & $\left({ }^{87} \mathrm{Sr} /{ }^{86} \mathrm{Sr}\right)_{\mathrm{i}}$ & $\begin{array}{c}\mathrm{Sm} \\
(\mathrm{ppm})\end{array}$ & $\begin{array}{c}\mathrm{Nd} \\
(\mathrm{ppm})\end{array}$ & ${ }^{147} \mathrm{Sm} /{ }^{144} \mathrm{Nd}$ & ${ }^{143} \mathrm{Nd} /{ }^{144} \mathrm{Nd}$ & $2 \sigma_{\mathrm{m}}$ & $\left({ }^{143} \mathrm{Nd} /{ }^{144} \mathrm{Nd}\right)_{\mathrm{i}}$ & $\varepsilon \mathrm{Nd}_{(0)}$ & $\varepsilon \mathrm{Nd}_{(\mathrm{T})}$ & $\begin{array}{l}T_{\mathrm{DM} 1} \\
(\mathrm{Ga}) \\
\end{array}$ & $\begin{array}{l}T_{\mathrm{DM} 2} \\
(\mathrm{Ga}) \\
\end{array}$ & $f_{\mathrm{Sm} / \mathrm{Nd}}$ \\
\hline \multicolumn{19}{|c|}{ Tephritic dyke } \\
\hline B-13 & 44 & 16.4 & 1082.9 & 0.043806 & 0.705129 & 11 & 0.705102 & 6.61 & 31.2 & 0.130097 & 0.512664 & 6 & 0.512627 & 0.52 & 0.89 & 0.89 & 0.78 & -0.34 \\
\hline \multicolumn{19}{|c|}{ Tephritic lava flow } \\
\hline B-3 & 47 & 27.8 & 1033.4 & 0.077812 & 0.704871 & 10 & 0.704819 & 5.89 & 25.8 & 0.135078 & 0.512712 & 6 & 0.512670 & 1.43 & 1.80 & 0.85 & 0.71 & -0.31 \\
\hline B-4 & 51 & 13.2 & 1046.4 & 0.036488 & 0.704895 & 10 & 0.704869 & 6.88 & 31.1 & 0.133549 & 0.512697 & 6 & 0.512652 & 1.15 & 1.56 & 0.86 & 0.73 & -0.32 \\
\hline B-10 & 44 & 22.3 & 1107.7 & 0.058231 & 0.704909 & 11 & 0.704872 & 6.79 & 30.1 & 0.132742 & 0.512713 & 6 & 0.512674 & 1.47 & 1.83 & 0.82 & 0.70 & -0.33 \\
\hline \multicolumn{19}{|c|}{ Basaltic dyke } \\
\hline B-1 & 46 & 84.2 & 857.4 & 0.284065 & 0.705313 & 10 & 0.705126 & 5.00 & 22.9 & 0.128298 & 0.512628 & 6 & 0.512589 & -0.20 & 0.20 & 0.93 & 0.84 & -0.35 \\
\hline \multicolumn{19}{|c|}{ Basaltic-trachytic lava flow } \\
\hline B-9 & 46 & 69.6 & 1099.5 & 0.183089 & 0.704356 & 14 & 0.704235 & 4.05 & 20.0 & 0.125913 & 0.512786 & 5 & 0.512748 & 2.90 & 3.32 & 0.63 & 0.58 & -0.36 \\
\hline
\end{tabular}

Uncertainties for the ${ }^{87} \mathrm{Sr} /{ }^{86} \mathrm{Sr}$ and ${ }^{143} \mathrm{Nd} /{ }^{144} \mathrm{Nd}$ ratios are $2 \sigma_{\mathrm{m}}$ errors in the last two digits. $\varepsilon \mathrm{Nd}_{(0)}$ values are calculated relative to CHUR with present-day values of ${ }^{143} \mathrm{Nd} /{ }^{144} \mathrm{Nd}=0.512638(\mathrm{Jacobsen}$ and $\mathrm{Wasserburg} 1980)$. $\mathrm{Nd}$ single-stage model ages $\left(\mathrm{T}_{\mathrm{DM} 1}\right)$ are calculated with a depleted-mantle reservoir and present-day values of ${ }^{143} \mathrm{Nd} /{ }^{144} \mathrm{Nd}=0.51315$ and ${ }^{147} \mathrm{Sm} /{ }^{144} \mathrm{Nd}=0.2137$. Nd two-stage model ages $\left(\mathrm{T}_{\mathrm{DM}}\right)$ are calculated with a depleted mantle reservoir and present-day values of ${ }^{143} \mathrm{Nd} /{ }^{144} \mathrm{Nd}=0.51315$ and ${ }^{147} \mathrm{Sm} /{ }^{144} \mathrm{Nd}=0.219$ (Liew and Hofmann 1988). 


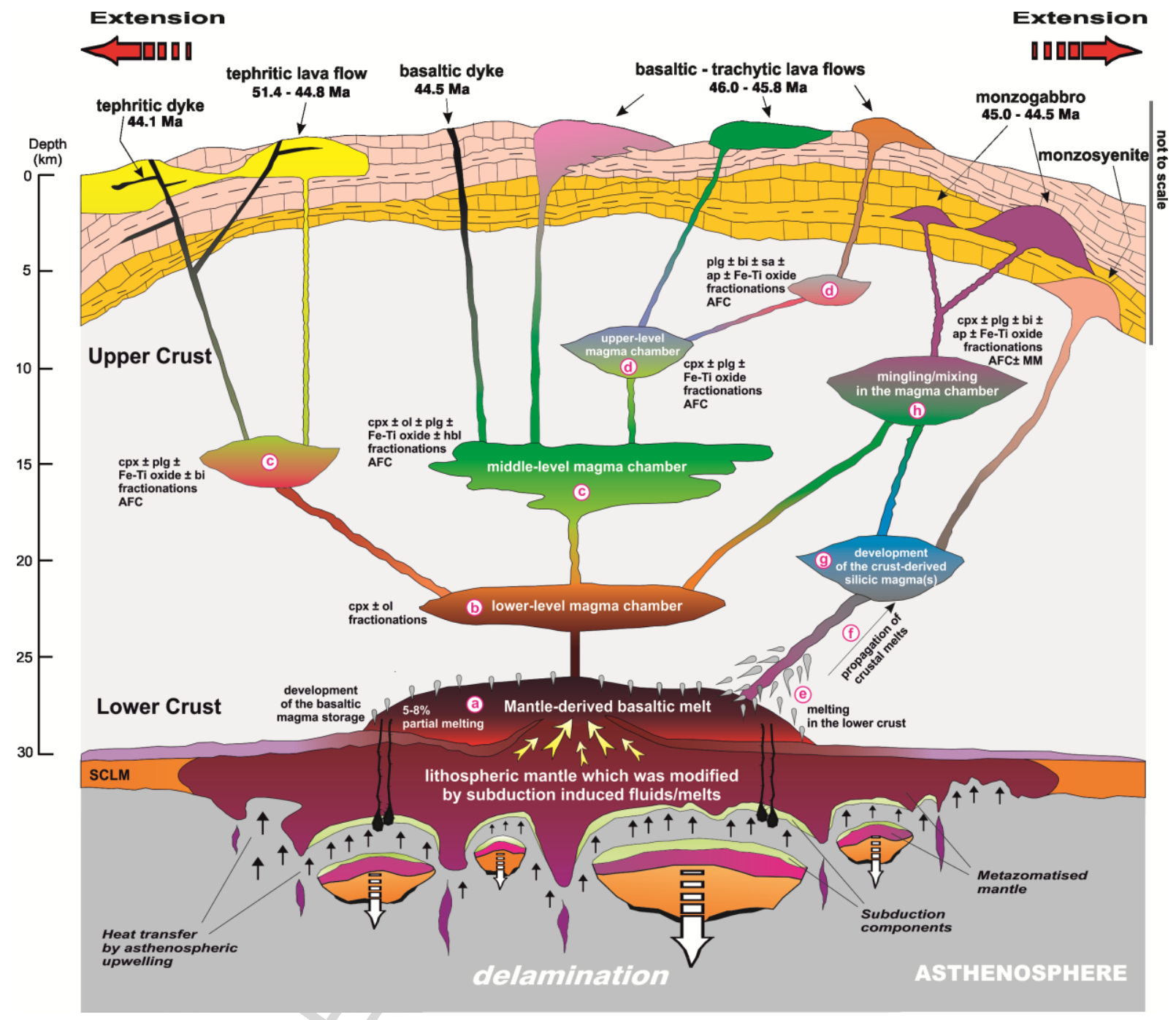

Graphical abstract 


\section{Highlights}

- Petrochemistry of the Eocene volcanics in N Turkey were studied.

- Sr-Nd isotope and Ar/Ar dating data were presented.

- The volcanics show evolutionary trends from high-K to shoshonitic.

- Source mixing and AFC modeling were evaluated.

- Parental magma(s) derived from decompression melting of SCLM. 